\title{
SECONDARY SUCCESSION ON DISTURBED SITES AT YUCCA MOUNTAIN, NEVADA
}

by

Jay P. Angerer, W. Kent Ostler, Warren D. Gabbert, and Brad W. Schultz

EG\&G Energy Measurements, Inc.

Environmental Sciences Division

Las Vegas, Nevada 


\section{DISCLAIMER}

This report was prepared as an account of work sponsored by an agency of the United States Government. Neither the United States Government nor any agency thereof, nor any of their employees, makes any warranty, expressed or implied, or assumes any legal liability or responsibility for the accuracy, completeness, or usefulness of any information, apparatus, product, or process disclosed, or represents that it's use would not infringe privately owned rights. Reference herein to any specific commercial product, product, or service by trade name, trademark, manufacturer, or otherwise, does not necessarily constitute or imply it's endorsement, recommendation, or favoring by the United States Government or any agency thereof. The views and opinions of authors expressed herein do not necessarily state or reflect those of the United States Government or any agency thereof.

This report has been reproduced directly from the best available copy.

Available to DOE and DOE contractors from the Office of Scientific and Technical Information, P. O. Box 62, Oak Ridge, TN 37831; prices available from (615) 576-8401.

Available to the public from the National Technical Information Service, U. S. Department of Commerce, 5285 Port Royal Road, Springfield, VA 22161. 


\section{DISCLAIMER}

Portions of this document may be illegible in electronic image products. Images are produced from the best available original document. 


\title{
SECONDARY PLANT SUCCESSION ON
}

DISTURBED SITES AT YUCCA MOUNTAIN,

NEVADA

\author{
by \\ Jay P. Angerer, W. Kent Ostler, Warren D. Gabbert, \\ and Brad W. Schultz
}

REVIEWED BY

W. K. Ostler, Director

Environmental Sciences Divison

This Document is UNCLASSIFIED

C. K. Mitchell

Classification Officer

DECEMBER 1994

This work was performed by EG\&G/EM for the United States Departments of Energy under Contract No. DE-AC08-93NV11265. 


\begin{abstract}
This report presents the results of a study of secondary plant succession on disturbed sites created during initial site investigations in the late 1970s and early 1980s at Yucca Mountain, NV. Specific study objectives were to determine the rate and success of secondary plant succession, identify plant species found in disturbances that may be suitable for site-specific reclamation, and to identify environmental variables that influence succession on disturbed sites. During 1991 and 1992, fifty seven disturbed sites were located. Vegetation parameters, disturbance characteristics and environmental variables were measured at each site. Disturbed site vegetation parameters were compared to that of undisturbed sites to determine the status of disturbed site plant succession. Vegetation on disturbed sites, after an average of ten years, was different from undisturbed areas. Ambrosia dumosa, Chrysothamnus teretifolius, Hymenoclea salsola, Gutierrezia sarothrae, Atriplex confertifolia, Atriplex canescens, and Stephanomeria pauciflora were the most dominant species across all disturbed sites. With the exception of $A$. dumosa, these species were generally minor components of the undisturbed vegetation. Elevation, soil compaction, soil potassium, and amounts of sand and gravel in the soil were found to be significant environmental variables influencing the species composition and abundance of perennial plants on disturbed sites. The recovery rate for disturbed site secondary succession was estimated. Using a linear function (which would represent optimal conditions), the recovery rate for perennial plant cover, regardless of which species comprised the cover, was estimated to be 20 years. However, when a logarithmic function (which would represent probable conditions) was used, the recovery rate was estimated to be 845 years. Recommendations for future studies and site-specific reclamation of disturbances are presented.
\end{abstract}




\section{ACKNOWLEDGEMENTS}

Many people have contributed to the completion of this report on secondary plant succession within disturbed habitats at Yucca Mountain. The following EG\&G/EM Environmental Sciences Division personnel helped set up study plots, collect data, enter data, and proof data: M. Wayne Fariss, Kevin W. Blomquist, Pam F. Hall, Glen E. Lyon, P. A. Chubb, Tim A. Lindemann, Aaron. M. Ambos, Brian R. Eller, Andy E. Gabbert, Shana L. Kozusko, Larry L. Lewis, Debi L. Pitts, Juan C. Medrano, Brett A. Rea, Katherine K. Zander, Kamila R. Sharp, Greg T. Sharp, Craig A. Callison, Charles R. Stanley, Rod G. Goodwin, Greg A. Brown, Dave S. Dixon, Stephanie A. Ferra, Tracey E. Walrath, Bart C. Odegaard, Mike W. Janis, Eric A. Holt, Terrence S. Trasatti, Matt D. Walo, James S. Woollet, Alicia C. Pool, Will H. Kohn, Chris L. Sowell, Shana L. Kozusko, Richard J. Delahunty, Adam Truran, David C. Walrath, Julie E. Fontaine, Sue M. Schultz, Wendy N. Finlay, Dan C. Steen, Adrienne M. Pilmanus, K. L. Griffin, L. S. Osborn. Valuable assistance in personnel scheduling and logistics was provided by the following individuals: David C. Anderson, Ron A. Green, Danny L. Rakestraw, and Cathy A. Wills. M. Wayne Fariss assisted in the analysis of the data. Glen E. Lyon created the plant database used to generate species names, life cycles and common names from the four-letter species codes used in data collection. The assistance of the following individuals in review of the first draft of this report is appreciated: Tom P. O'Farrell, Von K. Winkel, David C. Anderson, Kevin W. Blomquist, Mark A. Hessing, and Brian Cypher.

David C. Walrath, Steve Kowalkowski, Matt D. Walo, and Rose Broderick created the maps used in this report. Their assistance is greatly appreciated. 


\section{TABLE OF CONTENTS}

Section

Title

Page

ABSTRACT

ACKNOWLEDGEMENTS ii

1.0 PURPOSE

2.0 LITERATURE REVIEW 2

3.0 STUDY AREA DESCRIPTION $\ldots \ldots \ldots \ldots \ldots \ldots \ldots \ldots$

4.0 MATERIALS AND METHODS $\ldots \ldots \ldots \ldots \ldots \ldots \ldots \ldots \ldots$

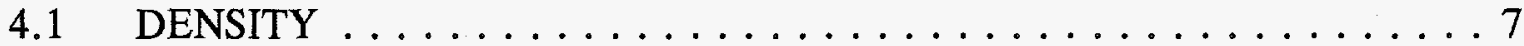

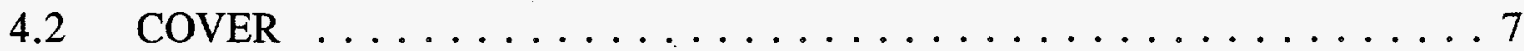

4.3 ENVIRONMENTAL VARIABLES $\ldots \ldots \ldots \ldots \ldots \ldots \ldots \ldots$

4.4 STATISTICAL ANALYSES $\ldots \ldots \ldots \ldots \ldots \ldots \ldots \ldots \ldots \ldots$

4.5 DOMINANCE DIVERSITY CURVES $\ldots \ldots \ldots \ldots \ldots \ldots \ldots \ldots 11$

4.6 SUCCESSION RATE CALCULATIONS $\ldots \ldots \ldots \ldots \ldots \ldots \ldots$

5.0 RESULTS . . . . . . . . . . . . . . . . . . . . . . . . . . 13

5.1 VEGETATION CHARACTERISTICS OF DISTURBED vs.

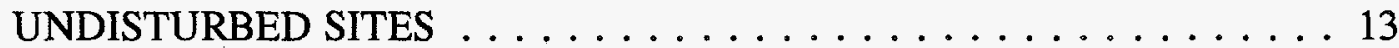

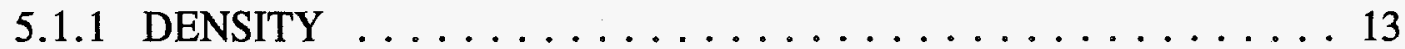

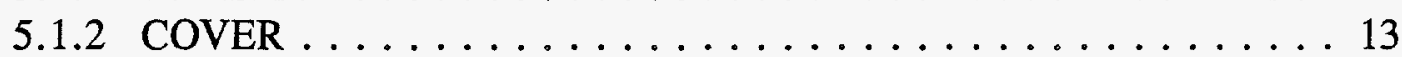

5.1 .3 SUCCESSION RATES . . . . . . . . . . . . . . 19

5.2 ENVIRONMENTAL CHARACTERISTICS OF DISTURBANCES $\ldots \ldots 24$

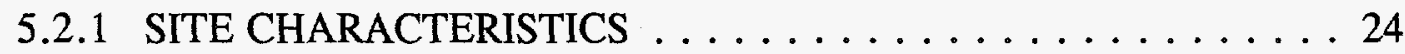

5.2 .2 SPECIES CHARACTERISTICS . . . . . . . . . . 26

5.3 CHARACTERISTICS OF DISTURBANCES WITHIN VEGETATION

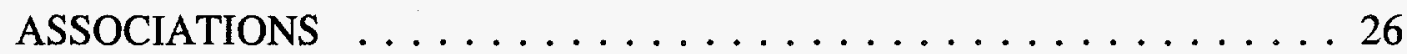

5.3.1 Lycium-Grayia Vegetation Association $\ldots \ldots \ldots \ldots \ldots . \ldots 28$

5.3.2 Larrea-Lycium-Grayia Vegetation Association . . . . . . . 32

5.3.3 Coleogyne Vegetation Association . . . . . . . . . . 38

5.3.4 Larrea-Ambrosia Vegetation Association . . . . . . . . . . . . . 42

5.4 CHARACTERISTICS OF DISTURBANCE TYPES $\ldots \ldots \ldots \ldots \ldots$

6.0 DISCUSSION . . . . . . . . . . . . . . . . . . 53

6.1 ENVIRONMENTAL VARIABLES INFLUENCING DISTURBED

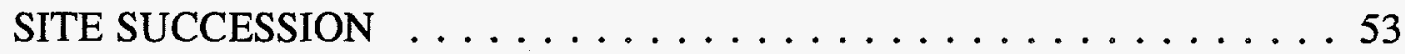

6.2 DISTURBED SITE PLANT SPECIES $\ldots \ldots \ldots \ldots \ldots \ldots$ 
6.3 NATURAL REVEGETATION SUCCESS $\ldots \ldots \ldots \ldots \ldots \ldots$

6.4 SUCCESSION RATES $\ldots \ldots \ldots \ldots \ldots \ldots \ldots \ldots \ldots \ldots \ldots$

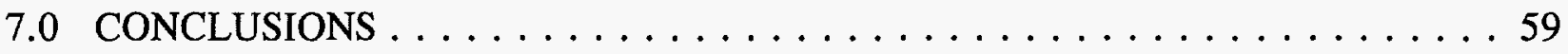

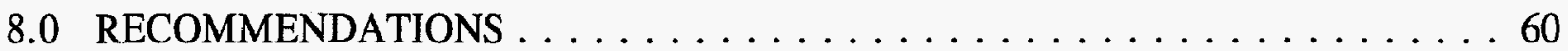

9.0 LITERATURE CITED . . . . . . . . . . . . . . . . . . . . . . 61

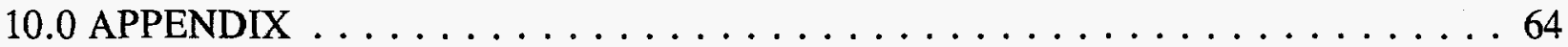




\section{ILLUSTRATIONS}

Figure

Title

Page

1. Location of Yucca Mountain, the disturbed habitat study area, and major

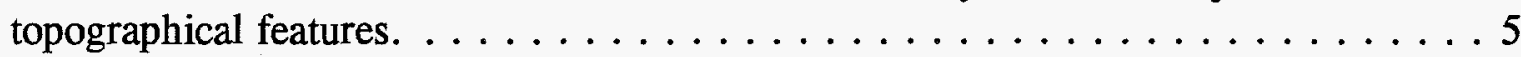

2. Mean monthly precipitation ( $\pm S D$ ) for gauge 4JA in Area 25 of the Nevada Test Site . . . . . . . . . . . . . . . . . . . . 6

3. Location of plant succession study plots (disturbed sites) and Ecological Study Plots (ESPs; undisturbed sites) used for plant density and cover data collection at Yucca Mountain, NV.

4. Generalized layout of transects and quadrats for cover and density measurements on disturbed areas at Yucca Mountain. . . . . . . . . . . . . 9

5. Mean density ( \pm SE) of total perennials, forbs, grasses and shrubs found on all disturbed and undisturbed sites inventoried in the disturbed habitat study at Yucca Mountain, NV.

6. Mean density ( \pm SE) of perennial plants found in disturbed and undisturbed sites at Yucca Mountain, NV . . . . . . . . . . . . . 15

7. Mean cover attributes $( \pm \mathrm{SE})$ for all disturbed and undisturbed sites inventoried for the disturbed habitat studies at Yucca Mountain, NV. . . . . . . . 16

8. Mean cover $( \pm \mathrm{SE})$ of perennial plant species found across all disturbed and undisturbed sites inventoried for the disturbed habitat studies at Yucca Mountain, NV . . . . . . . . . . . . . . . . . 17

9. Species richness (number) of perennial plant species found across all disturbed and undisturbed sites and in the Coleogyne (COL), Larrea-Ambrosia (LA), Lycium-Grayia (LG), and Larrea-Lycium-Grayia (LLG) vegetation associations

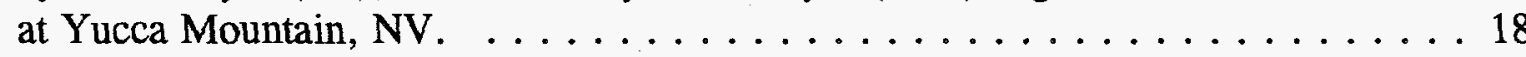

10. Mean cover $( \pm \mathrm{SE})$ of annual plant species found across all disturbed and undisturbed sites inventoried for the disturbed habitat studies at

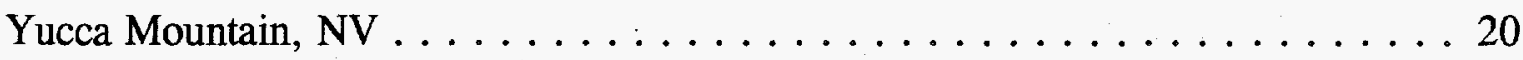

11. Linear and logarithmic regressions of the relationship between disturbed site cover (mean \pm SE) and years since disturbance $\ldots \ldots \ldots \ldots \ldots \ldots \ldots \ldots$ 
12. Canonical correspondence analysis (CCA) biplot for disturbed sites and significant environmental variables for Yucca Mountain, NV.

13. Canonical correspondence analysis (CCA) biplot for perennial plant species and associated significant environmental variables for disturbed sites at Yucca Mountain, NV . . . . . . . . . . . . . . . . . . . . . . . 27

14. Mean cover attributes $( \pm \mathrm{SE})$ for disturbed and undisturbed sites inventoried in the Lycium-Grayia vegetation association at Yucca Mountain, NV.

15. Mean cover $( \pm S E)$ of perennial plant species found on disturbed and undisturbed sites inventoried within the Lycium-Grayia vegetation association at Yucca Mountain, NV . . . . . . . . . . . . . . . . . . . . . 30

16. Dominance-diversity curves for relative cover (\%) of perennial plant species in disturbed and undisturbed areas within the Lycium-Grayia vegetation

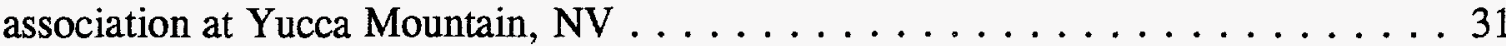

17. Canonical correspondence analysis (CCA) biplots for sites (a), perennial plant species (b) and their associated significant environmental variables

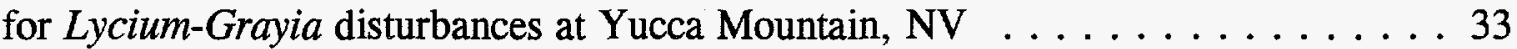

18. Mean cover attributes $( \pm$ SE) for disturbed and undisturbed sites inventoried in the Larrea-Lycium-Grayia vegetation association at Yucca Mountain, NV.

19. Mean cover $( \pm \mathrm{SE})$ of perennial plant species found on disturbed and undisturbed sites inventoried within the Larrea-Lycium-Grayia vegetation association at Yucca Mountain, NV . . . . . . . . . . . . . . 35

20. Dominance-diversity curves for relative cover (\%) of perennial plant species in disturbed and undisturbed areas within the Larrea-Lycium-Grayia vegetation association at Yucca Mountain, NV . . . . . . . . . . . . . . 36

21. Canonical correspondence analysis (CCA) biplots for sites (a), perennial plant species (b) and their associated significant environmental variables for Larrea-Lycium-Grayia disturbances at Yucca Mountain, NV . . . . . . . . . 37

22. Mean cover attributes $( \pm \mathrm{SE})$ for disturbed and undisturbed sites inventoried in the Coleogyne vegetation association at Yucca Mountain, NV.

23. Mean cover $( \pm \mathrm{SE})$ of perennial plant species found on disturbed and undisturbed sites inventoried within the Coleogyne vegetation association at Yucca Mountain, NV . . . . . . . . . . . . . . . . . . . . . . . 40 
24. Dominance-diversity curves for relative cover (\%) of perennial plant species in disturbed and undisturbed areas within the Coleogyne vegetation association at Yucca Mountain, $N V \ldots \ldots \ldots \ldots \ldots \ldots \ldots$

25. Mean cover attributes $( \pm$ SE) for disturbed and undisturbed sites inventoried in the Larrea-Ambrosia vegetation association at Yucca Mountain, NV.

26. Mean cover $( \pm \mathrm{SE})$ of perennial plant species found on disturbed and undisturbed sites inventoried within the Larrea -Ambrosia vegetation association at Yucca Mountain, NV .

27. Dominance diversity curves for relative cover (\%) of perennial plant species in disturbed and undisturbed areas within the Larrea-Ambrosia vegetation association at Yucca Mountain, NV . . . . . . . . . . . . . . . 45

28. Canonical correspondence analysis (CCA) biplot for disturbed sites and significant environmental variables for Yucca Mountain, NV

29. A borrow area (a) and cutslope (b) disturbance used for disturbed habitat studies at Yucca Mountain, NV. . . . . . . . . . . . . . . . 48

30. A drill pad (a) and a crushed vegetation disturbance (b) used for disturbed habitat studies at Yucca Mountain, NV.

31. Mean cover attributes ( \pm SE) for disturbance types and undisturbed sites inventoried for the disturbed habitat studies at Yucca Mountain, $\mathrm{NV} \ldots \ldots \ldots 50$

32. Species richness (number) of perennial plant species found in disturbance types and undisturbed sites at Yucca Mountain, NV . . . . . . . . . . 51

33. Dominance-diversity curves for relative cover (\%) of perennial plant species for disturbance types and undisturbed areas Yucca Mountain, NV . . . . . . 52 


\section{TABLES}

Table

1. Estimated rates of succession (years) for perennial plant species found in disturbed and undisturbed sites at Yucca Mountain, NV 


\section{APPENDIX TABLES}

Table

Title

Page

1. Codes, scientific names, common names, life cycle and growthform of plant species found in undisturbed and disturbed areas at Yucca Mountain, NV . . ........................665

2. Pearson's correlation coefficients (r) for environmental variables used to test for their influence on species composition and abundance in disturbance areas . . . 69

3. Code names and explanations for environmental variables used to determine their influence on species composition and abundance of plants on disturbed areas at Yucca Mountain, NV. . . . . . . . . . . . . . . 72 


\subsection{PURPOSE}

During the late 1970s and early 1980s, drill pads, borrow areas, cutslopes, and other construction disturbances were created during site investigations to evaluate Yucca Mountain as a study site for a potential nuclear waste repository. Many of these sites had vegetation and topsoil removed or had fill material spread over them to level the site. These disturbances provide an opportunity to study natural revegetation processes (i.e., secondary plant succession) at Yucca Mountain. In 1991, EG\&G/EM ESD implemented a disturbed habitat study to inventory past disturbances and to gain information on the successional processes occurring on disturbances at Yucca Mountain. Results from this study can provide insight into factors that control plant establishment on disturbances, aid in the development of reclamation studies, and ultimately aid in the development of techniques for reclaiming disturbed sites.

Three specific objectives of the study were outlined in the Reclamation Feasibility Plan (DOE 1990):

1) determine the rate and success of natural revegetation processes by comparing disturbed sites with adjacent undisturbed areas;

2) identify plant species found across all disturbances and within vegetation associations which are suitable for use in site-specific reclamation;

3) identify environmental variables at disturbances that may enhance site reclamation success.

The process of secondary plant succession can be described as the change in species composition from the time a disturbance has ceased until the vegetation at the site reaches an equilibrium and the species composition changes very little over time (Connell and Slatyer, 1977; Pickett et. al 1987). In deserts, this process can take many hundreds (Webb and Wilshire, 1980; Carpenter et al., 1986) to thousands of years for the equilibrium to occur (Vasek, 1979/80). Depending on the severity of the disturbance, secondary succession may create a plant community that is similar to the site prior to disturbance, or a plant community that is quite different (Webb et al., 1983). Plant species that occur on a site immediately after a disturbance may ameliorate the soils and microenvironment so that species that are not adapted to the harsh conditions of the disturbed site can later re-establish (Vasek, 1983).

The goal of this study is to better understand the natural succession process including the rate of succession at Yucca Mountain and what factors control or influence that rate. Application

of this information may then allow reclamation scientists to develop reclamation trials that can assess if successional factors can be controlled or ameliorated to enhance reclamation success. Information from the disturbed habitat study and the reclamation trials will ultimately be used in the development of site-specific reclamation plans to successfully restore disturbances at Yucca Mountain. 


\subsection{LITERATURE REVIEW}

Natural succession in the Mojave Desert appears to be a slow process (Vasek et al., 1975a b; Vasek, 1979/80; Romney et al., 1980; Wallace et al., 1980; Webb and Wilshire, 1980; Carpenter et al., 1986). Carpenter et al. (1986) reported that secondary succession on old fields in the eastern Mojave Desert require approximately 65 to 100 years for perennial plant cover to be comparable to that of undisturbed areas. Lathrop and Archbold (1980) estimated that the average recovery time for sites disturbed by utilities construction was 100 years and that more than 300 years may be required for long-lived perennials to re-establish. Vasek (1983) stated that natural revegetation of disturbed areas in the Mojave Desert is a process that may require centuries for the disturbed site to have comparable species composition and abundance, biomass, and structure to that of the original plant community.

Secondary succession studies conducted in the Mojave Desert have indicated that in the early seral stages, disturbed sites are dominated by short-lived and intermediate-lived plant species (Wells, 1961; Vasek et al., 1975a; Webb and Wilshire, 1980). Vasek (1979/80) reported that a severely disturbed borrow pit was dominated by short-lived shrubs such as Encelia frutescens and Stephanomeria pauciflora, whereas undisturbed areas surrounding the borrow pit were dominated by long-lived perennials such as Larrea tridentata and Opuntia bigelovii. The author concluded that the long-lived perennials were removed during disturbance and approximately 9 years was required for long-lived perennial seedlings to appear in the disturbed area. Vasek (1979/80) outlined three categories of plant species response to soil disturbance in the Mojave desert. The first group included pioneer or invader species such as Stephanomeria pauciflora and Encelia frutescens. These species tended to be short lived shrubs, suffrutescent or herbaceous perennials. The second group included long-lived opportunists such as Ambrosia dumosa that are eliminated after soil disturbance, but are present again shortly after the disturbance has ceased. The third group contained long-lived perennials species such as Larrea tridentata, Krameria grayii and Eriogonum fasciculatum which react negatively to deep soil disturbance and are generally removed from the site. Many years may be required for seedlings of these long-lived perennials to reappear in the disturbance; however, once established, these plants can persist for a great many years.

Several plant succession studies have been conducted on the Nevada Test Site (NTS). One such study was conducted at the Wahmonie ghost town (located in Area 25 of NTS, 20 kilometers east of Yucca Mountain). Wells (1961) reported that after 31 years, the disturbed areas at the Wahmonie site had greater numbers of Stipa speciosa, Hymenoclea salsola, and Ephedra nevadensis than undisturbed areas. Larrea tridentata and Grayia spinosa were absent in the disturbance, but were dominants in the undisturbed areas adjacent to the site. Webb and Wilshire (1980) visited the Wahmonie sites 24 years after the study conducted by Wells (1961). They noted that after 51 years, the most severely disturbed areas (former streets) had reduced densities of long-lived perennials such as Larrea tridentata, Grayia spinosa, and Lycium andersonii, which were dominant in the adjacent undisturbed areas. Cover of Hymenoclea salsola and Stipa speciosa was greater in the disturbed areas than in the adjacent undisturbed control. The authors noted that cover and density of perennials was greater in the 
disturbed area; however the species diversity was less in the disturbed site. The authors suggested that the rate of revegetation at the old town site was related to the soil compaction levels. Areas with high compaction levels had higher densities and cover of short-lived perennials, and lacked long-lived species such as Larrea and Grayia.

On land disturbed by grading to a depth of $15-20 \mathrm{~cm}$ in Area 25, Romney et al. (1989) reported an increase in the densities of Larrea tridentata and Ambrosia dumosa after above average rainfall during summer and winter months. The authors also noted that species such as Larrea tridentata , Ephedra nevadensis, and Lycium andersonii resprouted from exposed roots in the disturbed area. Plant succession studies were conducted at NTS to determine the effects of aboveground nuclear testing (Shields and Wells,1962; Shields et al., 1963). The annual species, Salsola kali, was found to have the highest density in areas with greatest soil disturbance created by nuclear blasts; however, the abundance of this species declined after 4 years (Shields et al., 1963). Within four years , perennial species such as Atriplex canescens, Hymenoclea salsola, Oryzopsis hymenoides, and Stipa speciosa increased in numbers on areas disturbed by atmospheric tests when compared with adjacent undisturbed areas (Shields et al., 1963).

Although the studies described above provide insight into the successional processes that occur in post-disturbance habitats of the Mojave Desert, they do not provide adequate information about successional processes at Yucca Mountain. Past studies did not examine and measure specific environmental variables (with the exception of soil compaction measurements of Webb and Wilshire, 1980) and how these relate to secondary plant succession. Past studies of Mojave Desert secondary plant succession tended to be restricted to only one disturbance type and speculations were made as to how environmental variables influenced successional patterns. In this study, the attempt was made to collect information to determine successional patterns at Yucca Mountain and assess how disturbance type, surrounding vegetation association and specific environmental variables influence these successional patterns. 


\subsection{STUDY AREA DESCRIPTION}

Yucca Mountain lies within the arid Basin and Range Province, a geographical region characterized by generally linear mountain ranges dissecting alluvial piedmont valleys with rugged, complex terrain features. Major topographical features of the area include Yucca Mountain itself, a long north-south aligned volcanic ridge, $1,494 \mathrm{~m}(4,855 \mathrm{ft})$ in elevation that slopes steeply (15 to 30 degrees) toward the west to Crater Flat (elevation $1,189 \mathrm{~m} ; 3,864$ $\mathrm{ft}$.), and gradually ( 5 to 10 degrees) toward the east in a series of highly dissected ridges to valleys of approximately $915 \mathrm{~m}(2,973 \mathrm{ft}$ ) in elevation (Figure 1). A large basin, Jackass Flats, and its associated Fortymile Canyon drainage, lie to the east of Yucca Mountain.

The climate of the Yucca Mountain area is characterized by strong solar insolation, limited and erratic precipitation, low relative humidity, and large diurnal temperature differences. No National Weather Service weather recording stations are present in the study area; however, precipitation data were collected from 1968 to 1992 at NTS monitoring gauge 4JA in Area 25. Average annual precipitation was $136.6 \mathrm{~mm}( \pm 68.9 \mathrm{SD})$. The greatest monthly average precipitation $(25.0 \mathrm{~mm} \pm 27.1 \mathrm{SD})$ was in March and the lowest average monthly precipitation (2.4 $\mathrm{mm} \pm 4.9 \mathrm{SD})$ was in June (Figure 2). Temperatures for the warmest month (July) averaged $35.6^{\circ} \mathrm{C}\left(96.1^{\circ} \mathrm{F}\right)$, while the coldest month (December) averaged 1.8 ${ }^{\circ} \mathrm{C}\left(35.2^{\circ} \mathrm{F}\right)$.

Two major floristic zones occur within the Yucca Mountain Project Area: the Mojave Desert zone, a warm desert occurring below 1,220 m (3,965 ft.); and a transition zone, often called the Transition Desert, which extends in a broad east-west corridor between the Mojave and the cooler, wetter Great Basin Desert found to the north of the site at elevations above $1,525 \mathrm{~m}$ $(4,956 \mathrm{ft})$ (Beatley 1976). Four primary vegetation associations (assemblages of areas with similar species composition and physiognomic characteristics) occur throughout the study area within these two floristic regions: Larrea-Ambrosia (Creosotebush-Bursage), Larrea-LyciumGrayia (Creosotebush-Boxthorn-Hopsage), Coleogyne (Blackbrush), and Lycium-Grayia (Boxthorn-Hopsage) (Beatley, 1976; O'Farrell and Collins, 1984). Each association is actually a mosaic of sub-associations consisting of dominant, co-dominant, and less abundant species of shrubs, grasses, and forbs; however, each association generally has similar physical characteristics and species composition that tend to differentiate it from other vegetation associations. 


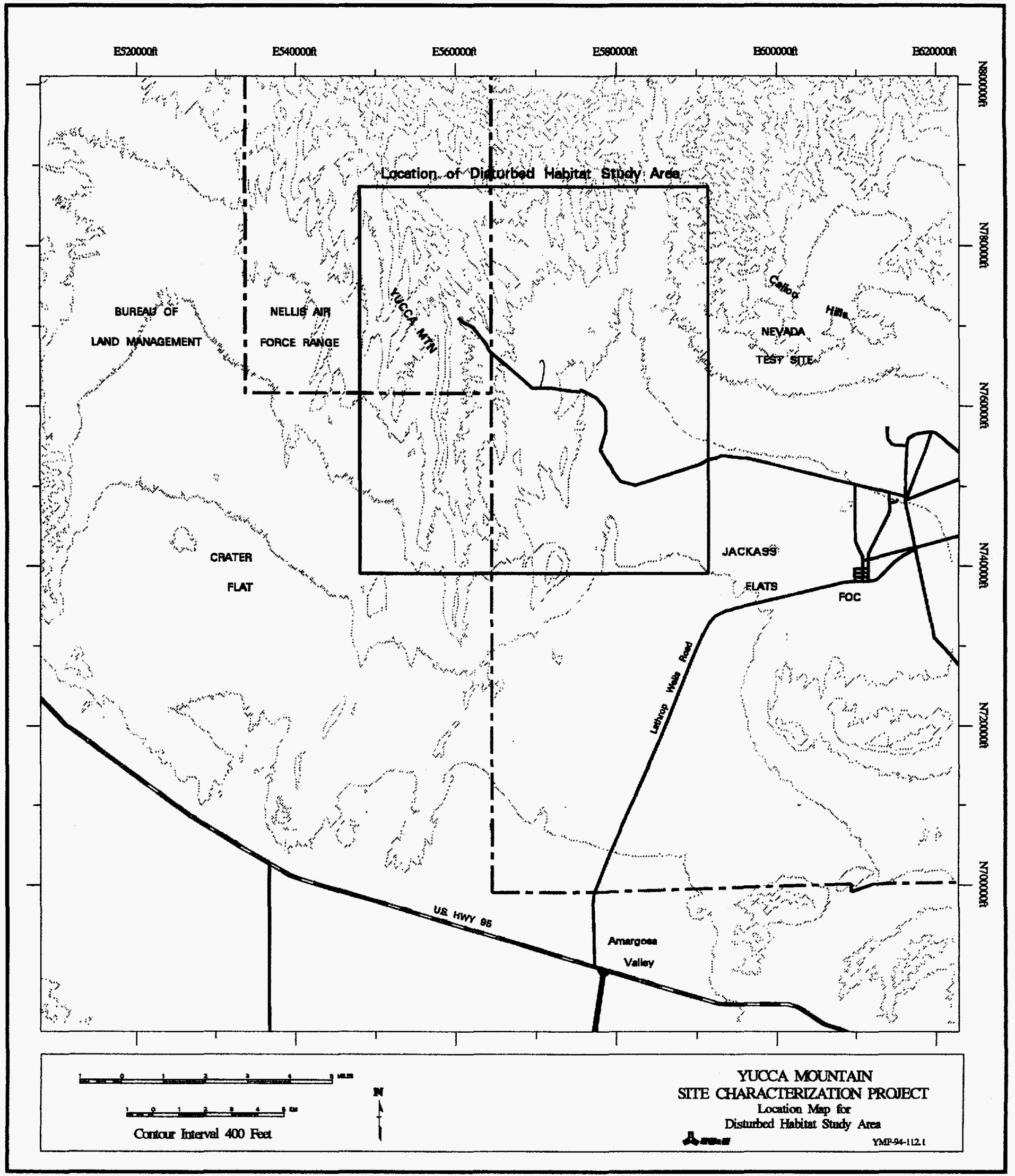

Figure 1. Location of Yucca Mountain, the disturbed habitat study area, and major topographical features. 
'Z66I pur 896I иәәмұәq

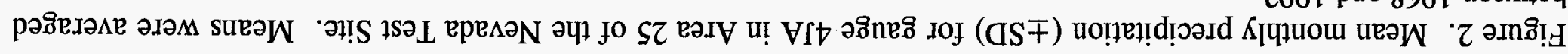

\section{$H \perp N O W$}

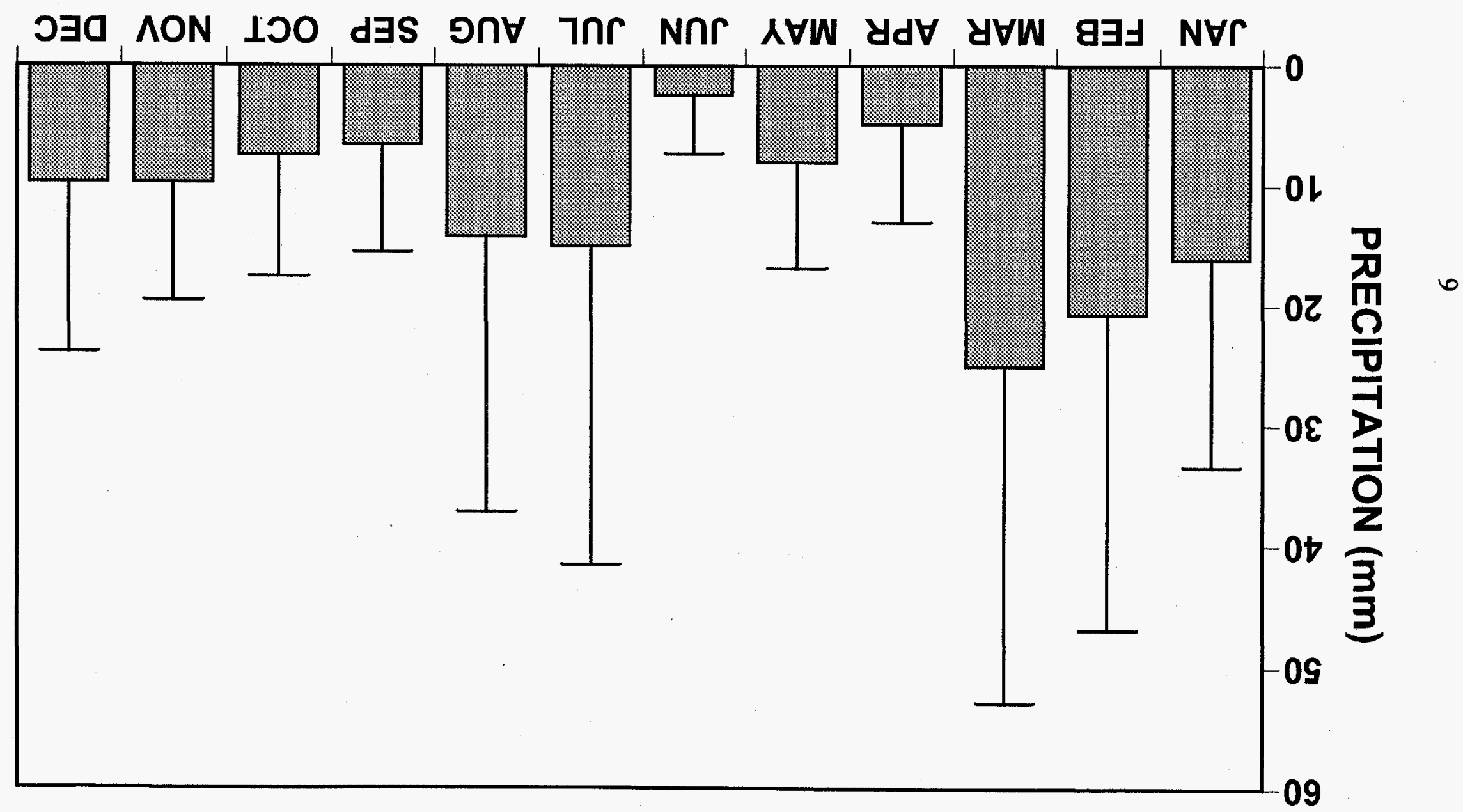




\subsection{MATERIALS AND METHODS}

During 1991, disturbances that were created prior to 1987 at Yucca Mountain were inventoried to determine their suitability for use in this study. Sites were chosen if the size and shape of the disturbance would accommodate a sufficient number of transects. Also, sites chosen were not active disturbances. Fifty-seven disturbed sites (Figure 3 ) were selected across all vegetation associations and the sites were classified by disturbance types (i.e. drill pads, cutslopes, etc.) that occur in the Yucca Mountain area.

Line and belt transects were established and quantitative vegetation measurements of cover and density were collected during July through October in 1991 and 1992. Depending on the size of the disturbance area, three to six line and belt transects were established. Transects were established at random distances from a defined baseline edge, and at one random distance from an edge perpendicular to the baseline edge (Figure 4). Line transects for cover measurements were $20-\mathrm{m}$ long and were generally established parallel to each other with distances between them exceeding $3 \mathrm{~m}$. Transects were installed perpendicular and downhill (if sloping) to the perceived direction of water runoff (Figure 4). Belt transects $(2 \times 20 \mathrm{~m})$ for density measurement were adjacent to each line transect.

\subsection{DENSITY}

For disturbance areas, density sampling occurred in belt transects $(2 \times 20 \mathrm{~m})$ adjacent to each 20-m cover transect. Each belt transect was divided into ten $2-x 2$-m quadrats. Live perennial species present in each quadrat (annual species were not recorded) were counted and summed. The summed values for a species were divided by the quadrat size and density was expressed as plants $/ \mathrm{m}^{2}$.

As with cover, 1992 density measurements from the ESPs were used for undisturbed area density. Density measurements collected on ESPs were similar to that of disturbance areas except that sampling occurred on eight to ten $2-\mathrm{x} 50-\mathrm{m}$ belt transects containing twenty-five 2 x 2-m quadrats. As with disturbed areas, density was expressed as plants $/ \mathrm{m}^{2}$.

\subsection{COVER}

Within disturbed areas, at 1-m intervals a long each line transect, five points were sampled using the ocular point cover technique. The ocular point cover technique was used because it has greater accuracy, improved efficiency, repeatability, and reduced sampler error (Buckner, 1985). One hundred points were sampled on each transect. When the ocular point intersected any living plant tissue, the plant species was recorded. If the point intersected dead plant material (e.g., a dead branch on a living plant) litter was recorded. If ground cover was intersected, either bare ground, gravel $(0.5$ to $8 \mathrm{~cm}$ size fraction), cobble $(8$ to $25 \mathrm{~cm})$, or rock $(>25 \mathrm{~cm}$ ) was recorded. The number of points for each species or ground cover attribute were summed and divided by the total number of points for each transect and expressed as a percentage. 


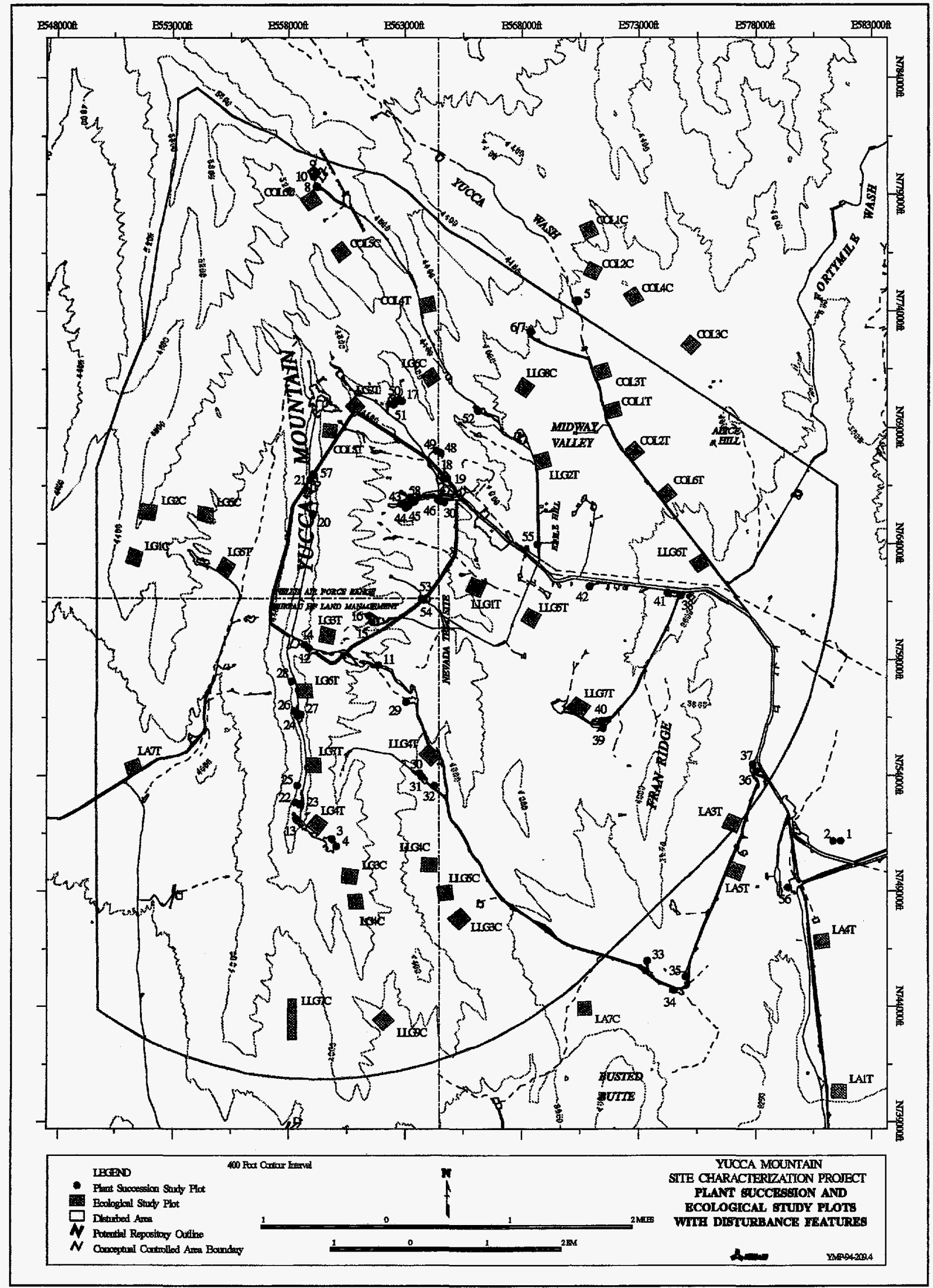

Figure 3. Location of plant succession study plots (disturbed sites) and Ecological Study Plots (ESPs; undisturbed sites) used for plant density and cover data collection at Yucca Mountain, NV. 


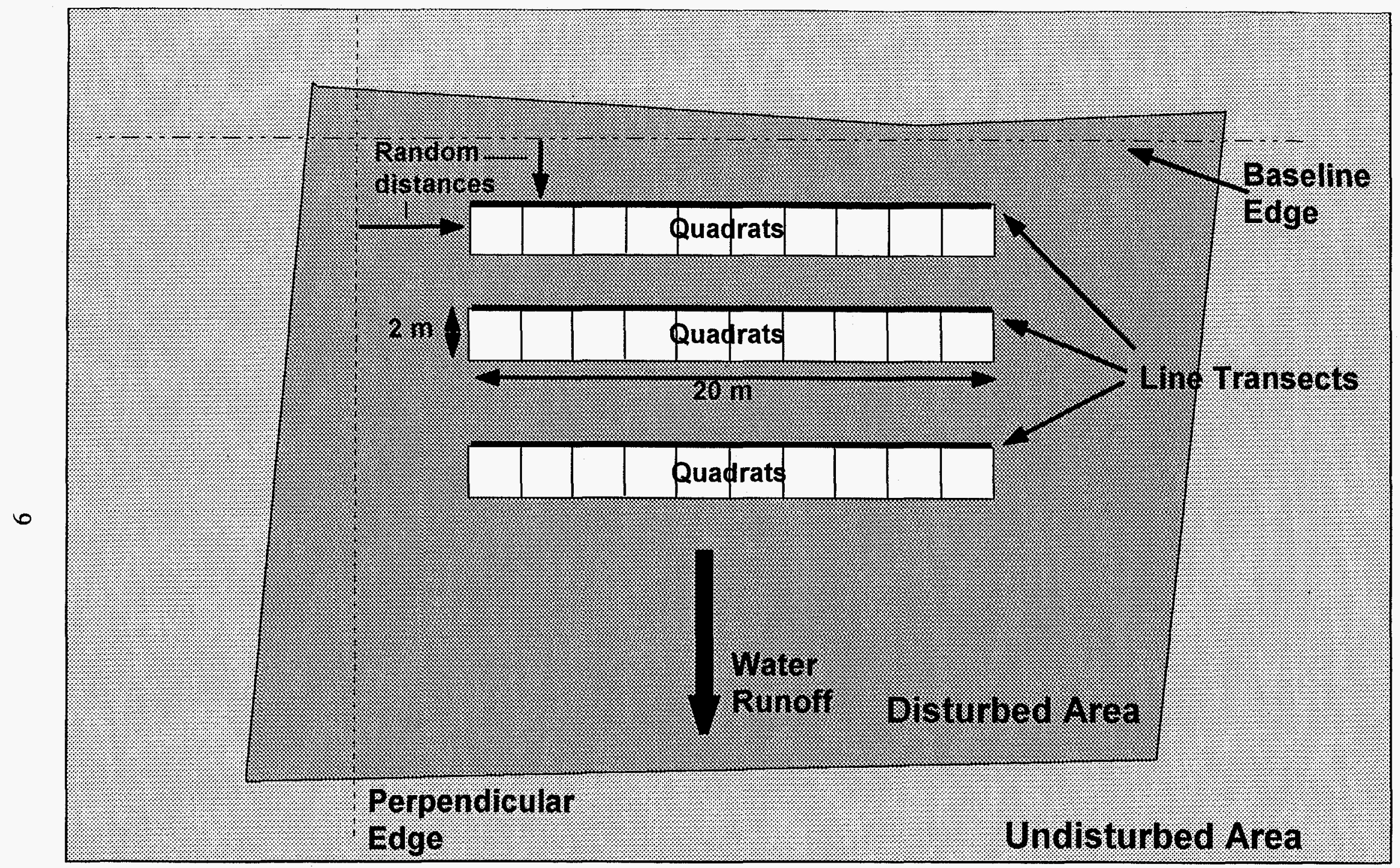

Figure 4. Generalized layout of transects and quadrats for cover and density measurements on disturbed areas at Yucca Mountain. 
Cover measurements collected in 1992 on the 48 Ecological Study Plots (ESPs) (Figure 3) as part of site characterization effects studies on vegetation were used as the undisturbed cover values to allow comparisons to be made with disturbed areas. Cover sampling on ESPs was similar to that in disturbed areas except that sampling occurred on eight to ten $50-\mathrm{m}$ line transects randomly located within each ESP.

\subsection{ENVIRONMENTAL VARIABLES}

After transects were established, site characteristics of the disturbed areas were recorded. Elevation, slope, aspect, size of the disturbance, and vegetation association of adjacent undisturbed areas were recorded for each site. Age of the disturbance was determined by site atlas records and phone interviews with supervisors for the construction activity that occurred on a particular disturbed area. Precipitation amounts since cessation of disturbance were calculated from daily precipitation at NTS gauge 4JA in Area 25.

At each disturbed site, soil samples were collected along each transect for soil physical and chemical properties analysis. Depending on uniformity of the soil, soil down to $30 \mathrm{~cm}$, or to bedrock, whichever was shallower, was collected at one or more locations along the transect and combined into a sample that represented the transect. A random portion of each transect sample was removed and combined with the other transect samples at each site. This combined sample represented the site soil sample and was sent to Utah State University Soil Testing Laboratory in Logan, UT for analysis. Specific physical properties analyzed included: percent sand, silt, and clay and percent gravel $>2 \mathrm{~mm}$. Specific chemical properties analyzed included: $\mathrm{pH}$; electrical conductivity; water soluble calcium, magnesium, and sodium; sodium absorption ratio; $\mathrm{NH}_{4}$ extractable calcium, magnesium, and sodium; phosphorus; nitratenitrogen; potassium; organic matter; cation exchange capacity (CEC); and exchangeable calcium, magnesium and sodium.

In order to determine degree of compaction and soil penetrability at each disturbed site, soil penetrometer readings were obtained. Two types of penetrometers were used. A depth penetrometer was used to record the depth of penetration into the soil surface. A cone penetrometer was used to record the penetration resistance $(\mathrm{kg} / \mathrm{cm} 2)$ of the soil surface. Penetrometer readings were taken at $2-\mathrm{m}$ intervals along each transect, within each disturbed area. Penetrometer readings were averaged across transects within a disturbed site and the average was used as the penetrometer value for a site.

\subsection{STATISTICAL ANALYSES}

For disturbed sites and undisturbed (ESPs) sites, individual quadrats acted as the experimental unit for calculation of density, and individual transects acted as the experimental unit for calculation of cover in the statistical analyses. For comparisons of sites, vegetation associations, and disturbance types, means and standard errors were calculated from the density and cover values for the experimental units. 
Individual disturbed sites acted as the experimental unit for analyses used to explore relationships among site density and cover, and environmental variables. Individual sites were chosen as experimental units for these analyses because soil analyses were for individual sites and because environmental variables such as elevation, slope, aspect, age and precipitation generally do not change from one quadrat or transect to another. CANOCO, a multivariate statistical package, was used to examine relationships among individual disturbed sites and their associated environmental variables. CANOCO uses canonical correspondence analysis (CCA) ordination (a method of arranging plant species or sites relative to their similarity to each other or to associated environmental factors (Kent and Coker,1992)) and multiple regression (ter Braak, 1986) to relate patterns of similarity in sites or plant species with environmental variables that are correlated to this pattern (Kent and Coker,1992). CANOCO then tests the significance of this relationship using a Monte Carlo permutation test (ter Braak, 1986).

\subsection{DOMINANCE DIVERSITY CURVES}

Dominance-diversity (also know as rank-abundance) curves were used to examine the successional status of disturbed sites compared to that of undisturbed sites. A dominancediversity curve integrates species richness, diversity, and evenness (how equal species abundances are to one another) into one diagram and allows comparisons of these attributes to other sites. The curve is a plot of the relative or proportional abundances of species for a site or sites on a log scale against their rank from most to least abundant, thus forming a curve that can be used in describing the evenness of species distribution and relative species dominance (Kent and Coker, 1992). If a site has a dominance diversity curve that is comparable to that of another site, then the sites are relatively close in their successional status. However, if the species on one site has completely different species ranks and shape of the dominancediversity curve than that of another site, this may indicate that these sites are in different successional trajectories.

\subsection{SUCCESSION RATE CALCULATIONS}

For this report, successional rate will be defined as the time required (in years) for a given vegetation parameter at a disturbed site to recover to a point that meets or exceeds that of adjacent undisturbed areas. Generally, in past studies of succession in the Mojave desert, the succession rate was calculated from the ratio of undisturbed to disturbed cover, density or biomass multiplied by the age of the disturbed site (e.g. Vasek et al., 1975a b; Lathrop and Archbold, 1980; Webb and Wilshire, 1980; Lathrop, 1983; Webb et al., 1988). The assumption behind this calculation is that the relationship between disturbed site age and the amount of a vegetation parameter is linear. In actuality, the relationship could be linear, exponential, or logarithmic due to species composition and environmental factors at a site. Vasek et al. (1975b) state that the relationship between age and a vegetation parameter is most likely not a linear relationship because plant growth curves are usually sigmoidal. The authors conclude that linear estimates are crude and are "far too optimistic". The linear calculation, based on the disturbed to undisturbed vegetation parameter ratio, is used by many researchers 
because of the lack of data points to conduct regression. Many of these studies represent the status of a disturbed site at a single point in time; therefore, only two data points can be regressed, time zero and the time at which data are collected.

In this study, the linear relationship was used to determine succession rates of individual species because this was a single point in time study and the window of disturb site ages was narrow ( 7 to 13 years since disturbance). Because of these two limitations, there were insufficient data points to conduct a statistically significant regression for individual species. Individual species succession rates were calculated by multiplying the cover or density undisturbed to disturbed ratio for a species by the average age of the disturbed sites.

Because succession rates calculated from the undisturbed to disturbed ratio is viewed as a crude and optimistic estimate, the succession rate for all sites was determined by conducting linear and nonlinear (logarithmic function) regression on disturbed site age and disturbed site perennial plant cover. The assumption was made that at zero time, cover of all disturbances was also zero. The resulting regression equations were then used to extrapolate the amount of time required for disturbed sites to reach the cover of undisturbed sites. 


\subsection{RESULTS}

Data on perennial plant density, perennial plant cover, annual plant cover and various cover attributes (bare ground, rock, litter, etc) were analyzed to determine vegetational characteristics of disturbed sites at Yucca Mountain. These characteristics were compared and contrasted to the surrounding undisturbed vegetation to determine the rate of recovery and the successional status of the disturbed areas. Disturbed area vegetation data were also analyzed to examine influences of environmental variables on disturbed site succession. Vegetation associations and disturbance types were investigated to determine their influence on patterns of vegetation at disturbed sites.

\subsection{VEGETATION CHARACTERISTICS OF DISTURBED vS. UNDISTURBED SITES}

\subsubsection{DENSITY}

Total perennial plant density means were $30 \%$ greater in undisturbed areas when compared to disturbances (Figure 5). Average shrub and grass density was higher in undisturbed areas than in disturbances; however, average forb densities were $200 \%$ greater in the disturbances (Figure 5). Plant species having the highest mean density across all disturbed sites were Chrysothamnus teretifolius, Gutierrezia sarothrae, Ambrosia dumosa, Stephanomeria pauciflora, and Eriogonum inflatum (Figure 6). With the exception of $A$. dumosa, these species generally had low mean densities in the undisturbed areas. Ephedra nevadensis, Coleogyne ramosissima, Menodora spinescens, Haplopappus cooperi, and Lycium andersonii had high mean densities across all undisturbed areas, but were minor components of the vegetation in disturbed areas (Figure 6).

\subsubsection{COVER}

Total perennial plant cover results were similar to that of density. Mean perennial plant cover on disturbed sites was 37\% less than that of undisturbed sites (Figure 7). Mean shrub, forb and grass cover on disturbed area was 1.5 to 2.2 times less than that on undisturbed sites (Figure 7). A. dumosa, C. teretifolius, Hymenoclea salsola, G. sarothrae, Atriplex canescens, and Atriplex confertifolia had the highest mean plant cover in the disturbed areas (Figure 8). Of these species, $C$. teretifolius, $G$. sarothrae, and $A$. canescens were minor components in the undisturbed areas; however, average cover of $H$. salsola and $A$. confertifolia at disturbed sites was comparable to that of undisturbed areas (Figure 8). As with density, the species having highest cover means across all undisturbed areas were $A$. dumosa, E. nevadensis, $C$. ramosissima, $M$. spinescens, and $L$. andersonii with the additions of Larrea tridentata and Grayia spinosa (Figure 8). Perennial species richness (number of separate species) was greater on undisturbed sites (Figure 9). Fifty eight perennial species were found across all undisturbed sites, whereas 43 species were found across all disturbances.

Bare ground, gravel, and cobble cover means were greater in disturbed areas. In contrast, plant litter cover was greater in the undisturbed areas (Figure 7). These differences are a 


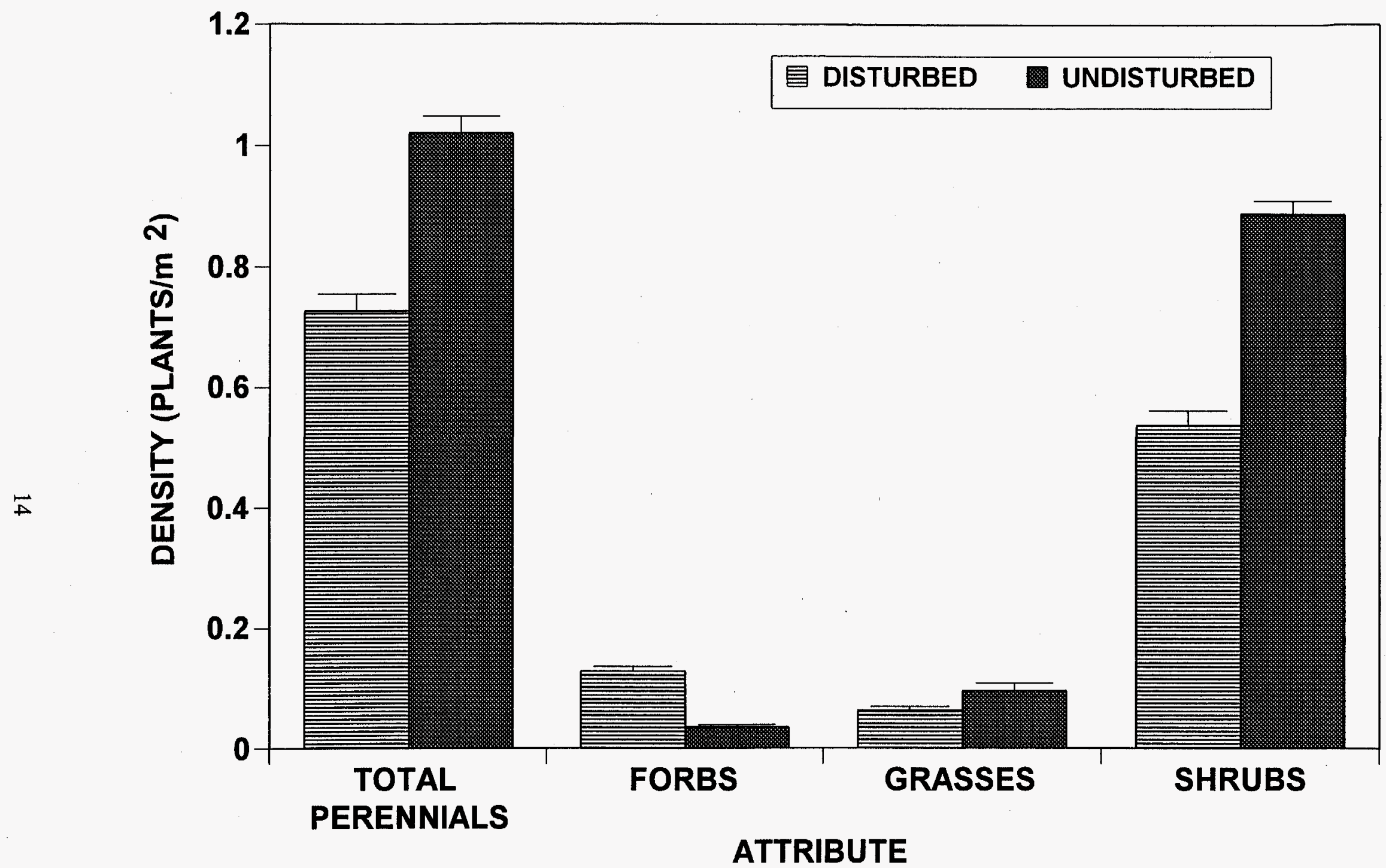

Figure 5. Mean density ( \pm SE) of total perennials, forbs, grasses and shrubs found on all disturbed and undisturbed sites inventoried in the disturbed habitat study at Yucca Mountain, NV. 


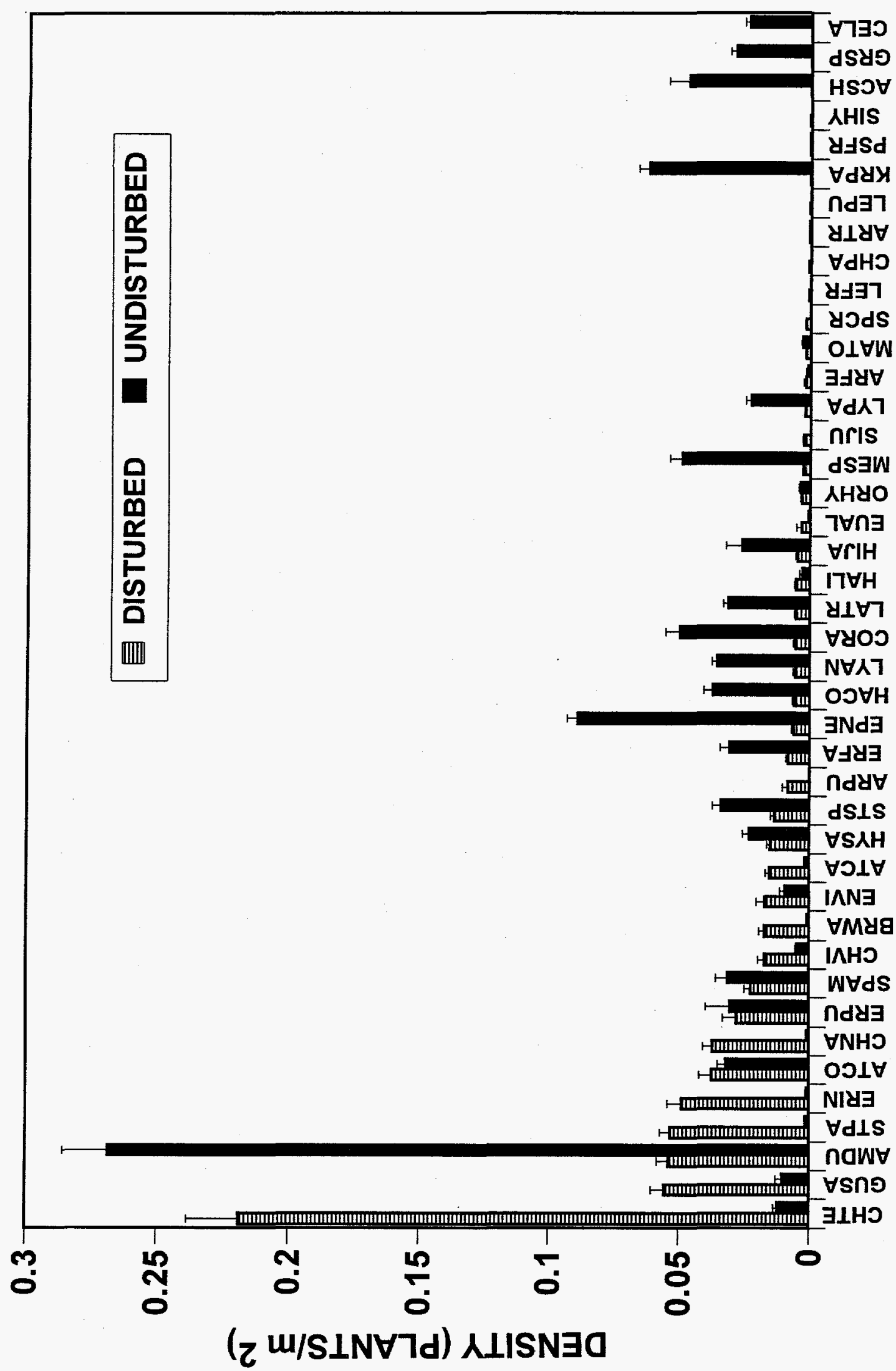

$\frac{\mathscr{U}}{0}$
क

z

焉

氠

ठृ

를 흔

$\boldsymbol{\Xi} \frac{0}{3}$

U1

$\overline{0}$

II

n

总造

.

응

응

ํํㄹ ซิ

흘

플 논

I

ฮิ

需

능

(I)

थ

$+18$

농으

氧

o

프

迅

6

웜

=

总 


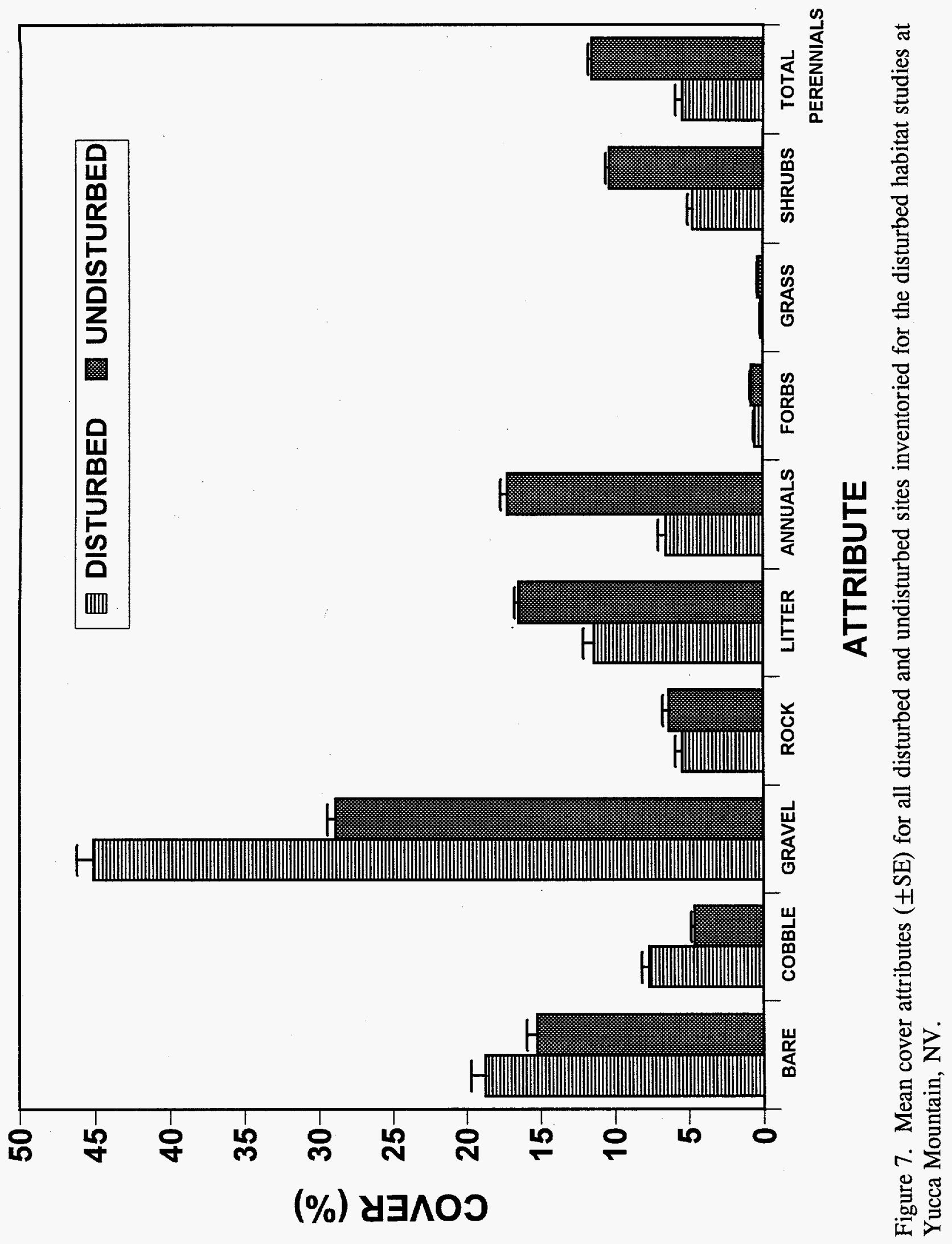




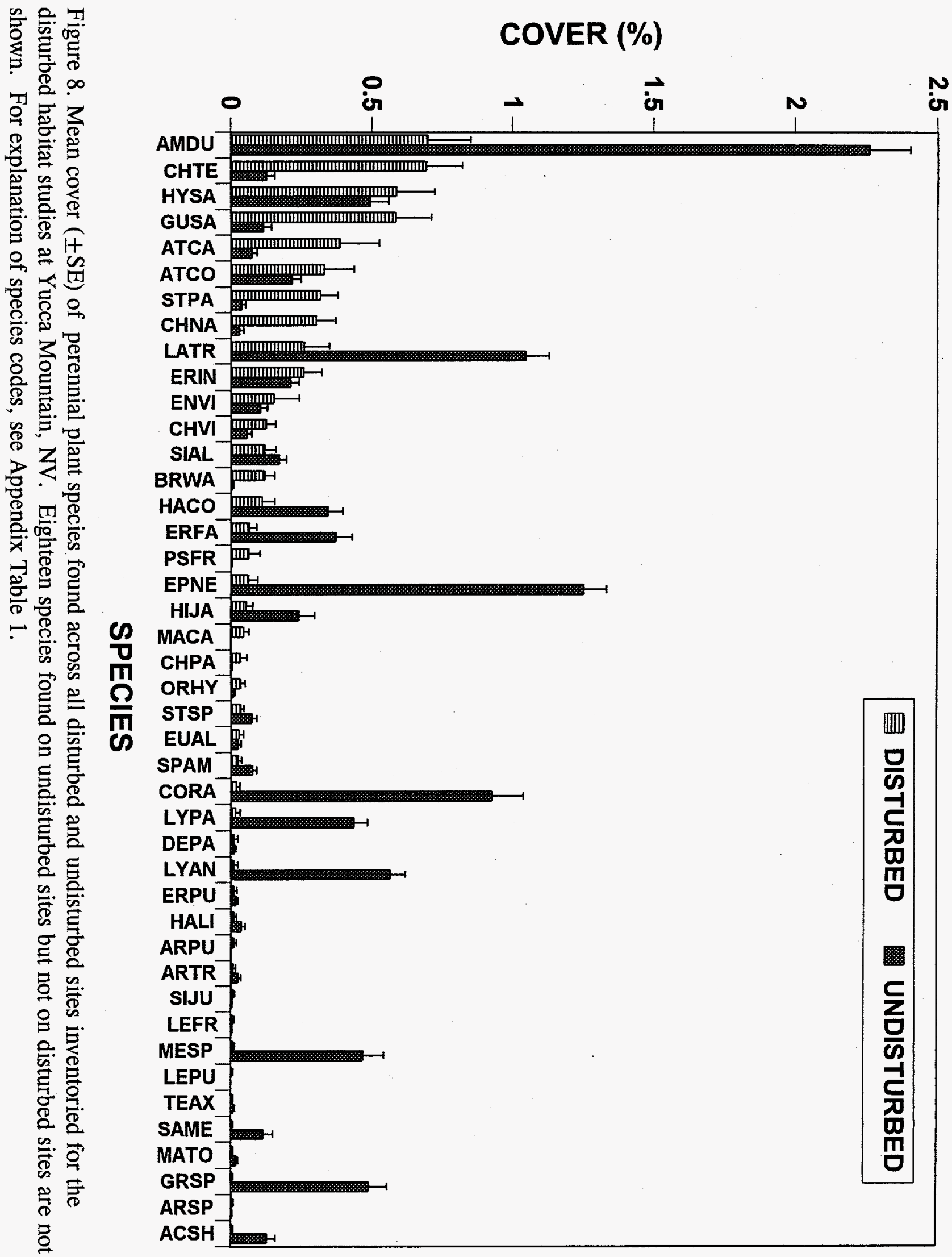




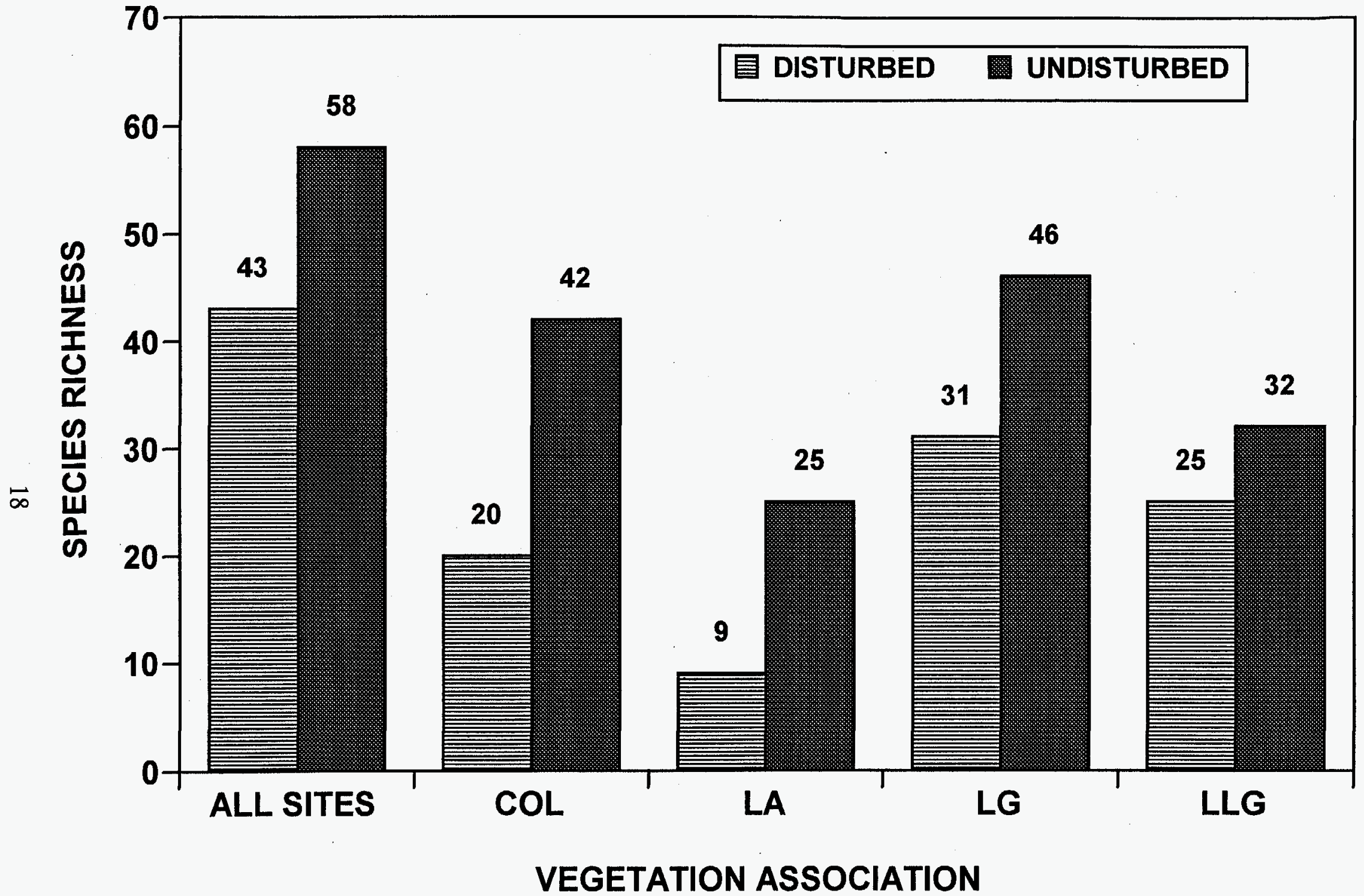

Figure 9. Species richness (number) of perennial plant species found across all disturbed and undisturbed sites and in the Coleogyne (COL), Larrea-Ambrosia (LA), Lycium-Grayia (LG), and Larrea-Lycium-Grayia (LLG) vegetation associations at Yucca Mountain, NV. 
reflection of the effects that soil and vegetation disturbance have on these cover attributes. The scraping or removal of soil at the time of disturbance has led to decreases in plant litter due to the destruction of the perennial vegetation.

Average annual plant cover was surprisingly greater on the undisturbed areas when compared to disturbed areas (Figure 7). This may be a artifact of the data collection. Annual species data on undisturbed areas was collected during the early spring, when many of the annual plants were actively growing. Annual plant cover on the disturbed sites was collected during the summer and early fall when many of the annuals probably had died and disappeared by this time. Another reason for the larger amount of annual cover on the undisturbed areas may be the influence of Bromus rubens, which had the highest plant cover on undisturbed sites (Figure 10). This cover mean was almost 3 times greater than Salsola iberica which had the highest annual plant cover in disturbed areas. S. iberica, Eriogonum deflexum, and Halogeton glomeratus had the highest annual plant cover in the disturbed sites, but were minor components or completely absent from undisturbed sites (Figure 10). B. rubens and Amsinckia tessellata had the highest cover in undisturbed areas, and were major components of the annual plant densities in disturbed sites (Figure 10).

\subsubsection{SUCCESSION RATES}

Using the perennial cover means for all disturbed and undisturbed sites, secondary succession rates were estimated using linear and non-linear (logarithmic function) regressions (Figure 11). The linear regression is meant to represent an "optimistic" rate and the logarithmic function regression is meant to represent a probable succession rate since this function is more representative of plant growth and successional processes. An extrapolation of the linear regression indicated that perennial cover on disturbances would reach that of undisturbed areas after 20 years. Extrapolation with the logarithmic function indicated that disturbed site perennial cover will be 80 percent of the undisturbed site cover after 130 years, 90 percent after 330 years, and 100 percent after 845 years. The gap in the number of years required for disturbed sites to achieve 100 percent cover of the undisturbed sites for the linear and logarithmic estimates is quite large and a result of the differences in these functions. For the linear function, the increase in perennial cover is equal over time. However, for the logarithmic function, perennial cover increases at an increasing rate during the first three years, then increases at a decreasing rate for the remaining time. The results of the regressions in Figure 11, whether linear or logarithmic, should be interpreted with caution. The succession rates depicted are for total perennial cover of the disturbed and undisturbed sites and does not take into consideration what species comprise the cover of the sites.

For individual species across all sites, estimated succession rates calculated from the ratio of undisturbed to disturbed cover/density multiplied by the average age of the disturbed sites were quite variable (Table 1). For example, the estimated succession rate for A. dumosa and $L$. tridentata cover to approach that of undisturbed sites was 31 and 39 years, respectively. However, rates for C. ramosissima, $L$. andersonii, and G. spinosa were 418,425 and 1,101 years, respectively. Species such as $A$. confertifolia and $H$. salsola had 


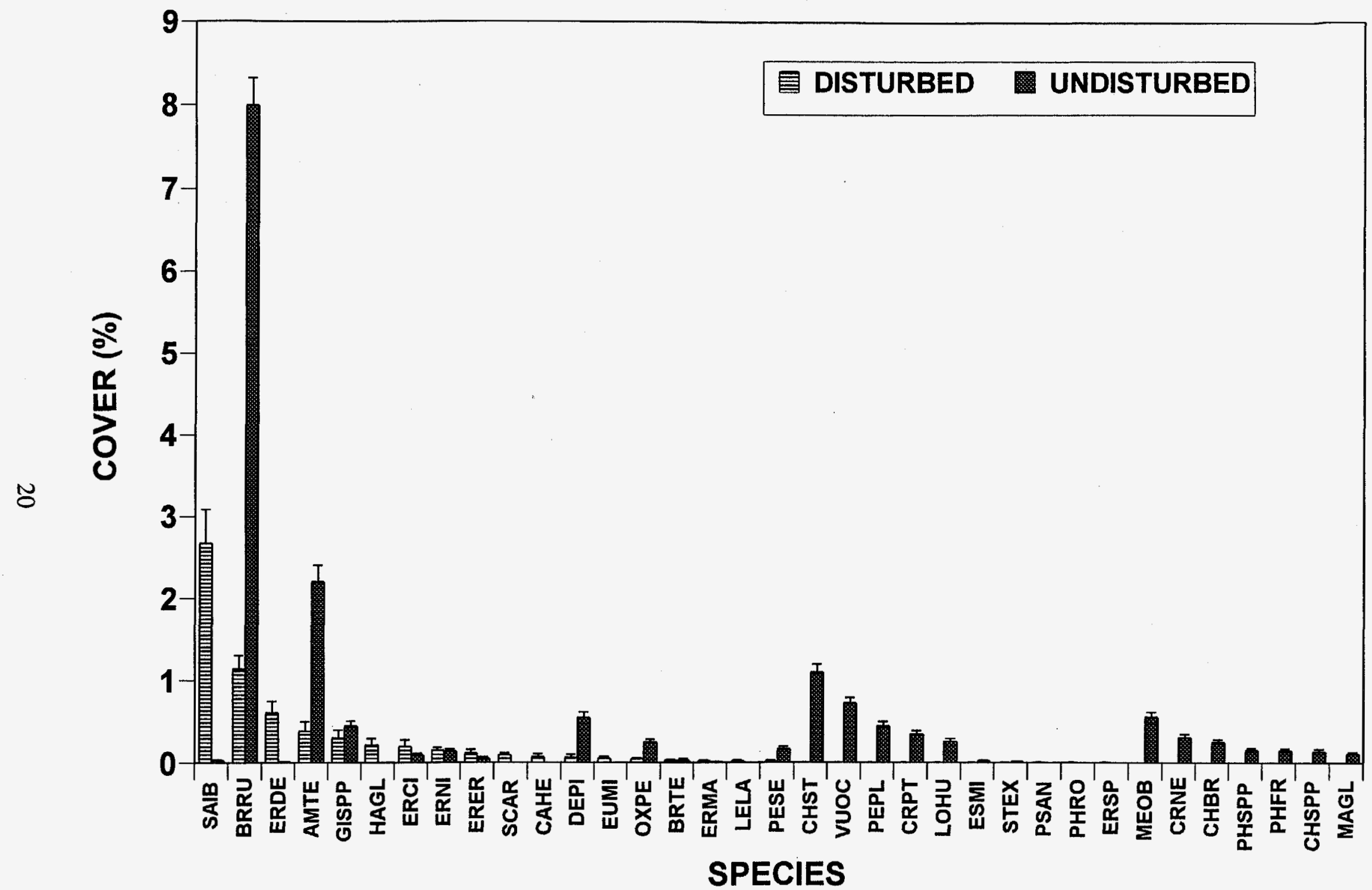

Figure 10. Mean cover $( \pm \mathrm{SE})$ of annual plant species found across all disturbed and undisturbed sites inventoried for the disturbed habitat studies at Yucca Mountain, NV. Seventeen species having cover values less than $0.1 \%$ are not shown. For explanation of species codes, see Appendix Table 1. 


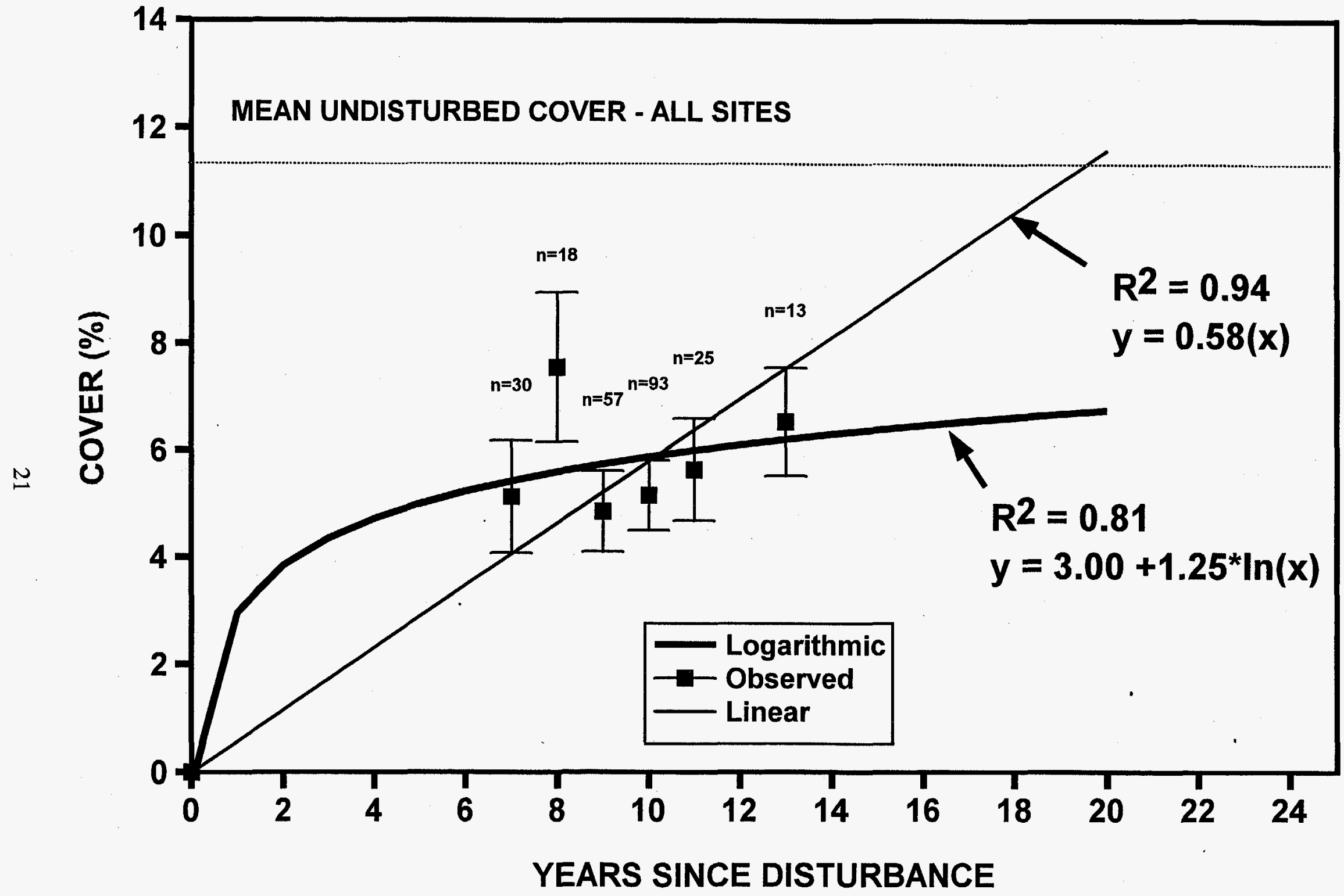

Figure 11. Linear and logarithmic regressions of the relationship between disturbed site cover (mean $\pm S E$ ) and years since disturbance. Regression equations were used to estimate succession rates for disturbances. 
Table 1. Estimated rates of succession (years) for perennial plant species found in disturbed and undisturbed sites at Yucca Mountain, NV. Rates were calculated by multiplying the ratio of undisturbed to disturbed cover or density by the average age of the site. Succession rates are given for individual species averaged across sites and within the Lycium-Grayia (LG), Larrea-Lycium-Grayia (LLG), Coleogyne (COL), and the Larrea-Ambrosia vegetation associations. Succession rates based on perennial plant density are for all sites combined. Species having a "?", indicate that this species occurred in the undisturbed area but not in the disturbed area represented by the column, therefore a rate cannot be determined. Species having a blank indicate that they did not occur in either the disturbed or undisturbed areas represented by the column.

\begin{tabular}{|c|c|c|c|c|c|c|c|}
\hline \multirow[b]{2}{*}{ Scientific name } & \multirow{2}{*}{$\begin{array}{l}\text { Species } \\
\text { Code } \\
\end{array}$} & \multicolumn{5}{|c|}{ Cover } & \multirow{2}{*}{$\begin{array}{r}\text { Density } \\
\text { All } \\
\text { Sites } \\
\end{array}$} \\
\hline & & Sites & LG & LLG & $\mathrm{COL}$ & LA & \\
\hline Acamptopappus shockleyi & $\mathrm{ACSH}$ & 287 & $?$ & $?$ & & 109 & 1487 \\
\hline Ambrosia dumosa & AMDU & 31 & 65 & 14 & 471 & 16 & 48 \\
\hline Aristida longiseta & ARFE & & 6 & & & & \\
\hline Aristida purpurea & ARPU & 0 & 0 & & & & 0 \\
\hline Artemesia spinescens & ARSP & 5 & 0 & $?$ & & & 25 \\
\hline Artemesia tridentata & ARTR & 29 & $?$ & & 0 & & 9 \\
\hline Astragalus layneae & ASLA & $?$ & & & $?$ & $?$ & $?$ \\
\hline Atriplex canescens & ATCA & 2 & 8 & 4 & 0 & & 1 \\
\hline Atriplex confertifolia & ATCO & 6 & 16 & $?$ & 16 & $?$ & 8 \\
\hline Brickellia watsonii & BRWA & 0 & 1 & 0 & & & 0 \\
\hline Castilleja chromosa & $\mathrm{CACH}$ & & $?$ & & & & \\
\hline Calochortus flexuosus & CAFL & $?$ & $?$ & & $?$ & & $?$ \\
\hline Ceratoides lanata & CELA & $?$ & $?$ & ? & $?$ & $?$ & 752 \\
\hline Chrysothamnus nauseosus & CHNA & 1 & 4 & 0 & 2 & & 0 \\
\hline Chrysothamnus paniculatus & CHPA & 1 & 0 & & & 1 & 0 \\
\hline Chrysothamnus teretifolius & CHTE & 2 & 10 & 0 & 3 & & 1 \\
\hline Chrysothamnus viscidiflorus & CHVI & 4 & 15 & 0 & 8 & & 3 \\
\hline Coleogyne ramosissima & CORA & 418 & $?$ & $?$ & 241 & $?$ & 89 \\
\hline Delphinium parishii & DEPA & 10 & $?$ & 0 & $?$ & & $?$ \\
\hline Descurainia sophia & DESO & & $?$ & & & & \\
\hline Dichelostemma pulchellum & DIPU & $?$ & & & $?$ & & \\
\hline Echinocereus engelmanii & ECEN & $?$ & & & $?$ & & ? \\
\hline Echinocactus polycephalus & ECPO & $?$ & $?$ & & & & $?$ \\
\hline Encelia virginensis & ENVI & 7 & 4 & 9 & 125 & & 5 \\
\hline Ephedra nevadensis & EPNE & 188 & 400 & 226 & $?$ & $?$ & 139 \\
\hline Ephedra viridis & EPVI & $?$ & $?$ & & $?$ & & 143 \\
\hline Eriogonum fasciculatum & ERFA & 53 & 730 & 4 & $?$ & 0 & 36 \\
\hline Eriogonum inflatum & ERIN & 8 & 6 & 18 & $?$ & 13 & 0 \\
\hline Eriogonum microthecum & ERMI & & 64 & & & & \\
\hline Erioneuron pulchellum & ERPU & 14 & 20 & $?$ & & & 10 \\
\hline Eriogonum umbellatum & ERUM & $?$ & & & $?$ & & \\
\hline Euphorbia albamarginata & EUAL & 8 & 20 & 7 & $?$ & & 2 \\
\hline Grayia spinosa & GRSP & 1101 & $?$ & 51 & $?$ & $?$ & 912 \\
\hline
\end{tabular}




\begin{tabular}{|c|c|c|c|c|c|c|c|}
\hline \multirow[b]{2}{*}{ Scientific name } & \multirow[b]{2}{*}{$\begin{array}{l}\text { Species } \\
\text { Code }\end{array}$} & \multicolumn{5}{|c|}{ Cover } & \multirow{2}{*}{$\begin{array}{r}\text { Density } \\
\text { All } \\
\text { Sites }\end{array}$} \\
\hline & & $\begin{array}{r}\text { All } \\
\text { Sites } \\
\end{array}$ & $\mathrm{LG}$ & LLG & $\mathrm{COL}$ & $\mathrm{LA}$ & \\
\hline Gutierrezia sarothrae & GUSA & 2 & 7 & & 11 & & 2 \\
\hline Haplopappus cooperi & HACO & 30 & 202 & 7 & 2 & $?$ & 61 \\
\hline Haplopappus linearifolius & HALI & 28 & 148 & & 4 & & 5 \\
\hline Hilaria jamesii & HIJA & 42 & 454 & & 5 & & 54 \\
\hline Hymenoclea salsola & HYSA & 8 & 50 & 5 & 6 & & 15 \\
\hline Juniperus osteosperma & JUOS & & $?$ & & & & \\
\hline Krameria parvifolia & KRPA & $?$ & $?$ & $?$ & $?$ & $?$ & 1475 \\
\hline Larrea tridentata & LATR & 39 & 93 & 29 & $?$ & 54 & 56 \\
\hline Lepidium densiflorum & LEDE & $?$ & $?$ & $?$ & $?$ & $?$ & \\
\hline Lepidium fremontii & LEFR & 3 & 20 & & 0 & & 1 \\
\hline Leptodactylon pungens & LEPU & 0 & 0 & & & & 6 \\
\hline Lycium andersonii & LYAN & 425 & $?$ & 66 & $?$ & $?$ & 62 \\
\hline Lycium pallidum & LYPA & 245 & $?$ & $?$ & $?$ & 51 & 108 \\
\hline Machaeranthera canescens & MACA & 0 & 0 & 0 & 0 & & \\
\hline Machaeranthera tortifolia & MATO & 42 & 0 & & $?$ & $?$ & 18 \\
\hline Menodora spinescens & MESP & 528 & $?$ & 165 & 14 & $?$ & 179 \\
\hline Mirabilis bigelovii & MIBI & $?$ & $?$ & $?$ & & & 20 \\
\hline Muhlenbergia porteri & MUPO & $?$ & $?$ & & & & $?$ \\
\hline Opuntia basilaris & OPBA & & 126 & & & & \\
\hline Opuntia echinocarpa & OPEC & & $?$ & & & & \\
\hline Oryzopsis hymenoides & ORHY & 3 & 3 & 0 & & $?$ & 12 \\
\hline Psorothamnus fremontii & PSFR & 0 & & 0 & & $?$ & 14 \\
\hline Psorothamnus polydenius & PSPO & $?$ & & $?$ & & & \\
\hline Salazaria mexicana & SAME & 261 & $?$ & 176 & $?$ & & $?$ \\
\hline Sclerocactus polyancistrus & SCPO & $?$ & $?$ & & & & $?$ \\
\hline Sisymbrium altissimum & SIAL & 14 & 13 & 6 & $?$ & $?$ & \\
\hline Sitanion hystrix & SIHY & $?$ & $?$ & & $?$ & & 2 \\
\hline Sitanion jubatum & SIJU & 3 & & $?$ & 0 & & 0 \\
\hline Sphaeralcea ambigua & SPAM & 29 & 204 & 3 & 4 & & 13 \\
\hline Stephanomeria pauciflora & STPA & 1 & 4 & 1 & 2 & 0 & 0 \\
\hline Stipa speciosa & STSP & 21 & 67 & $?$ & $?$ & $?$ & 24 \\
\hline Tetradymia axillaris & TEAX & 21 & $?$ & $?$ & $?$ & 0 & $?$ \\
\hline Yucca brevifolia & YUBR & $?$ & & & $?$ & & 4 \\
\hline Average site age & & 9.6 & 9.4 & 9.6 & 10.4 & 9.4 & 9.6 \\
\hline
\end{tabular}


succession rates of 6 and 8 years, respectively, indicating how quickly these species recover from disturbance. Again, these estimates are based on the assumption that the rate of succession is linear, so these values should be interpreted as optimistic.

\subsection{ENVIRONMENTAL CHARACTERISTICS OF DISTURBANCES}

For determination of the influence of important environmental variables on disturbed site plant succession, perennial plant cover was chosen as the analysis variable. Perennial plant cover was chosen over density and total plant cover because it does not fluctuate widely from year to year. Total plant cover fluctuates yearly due to the influence of annual plants, and plant density numbers can be skewed by an abundance of seedlings in one year that may die before the next year. Therefore, perennial plant cover is probably the best variable for point in time comparisons such as in this study. Also, perennial plant cover integrates plant frequency, density, and size (canopy area) into one analysis variable.

\subsubsection{SITE CHARACTERISTICS}

Using the perennial plant cover species means and the mean values for environmental variables for individual sites, ordination was conducted to determine patterns of similarity in sites and the environmental variables that influence these patterns. Canonical correspondence analysis (CCA) ordination indicated that elevation, soil potassium, percent sand in the soil, percent gravel $>2 \mathrm{~mm}$ in the soil, and soil penetration resistance (compaction) were significant ( $p$ $<0.05$ ) environmental variables (Figure 12). In Figure 12, a biplot of the sites and influencing environmental variables is presented. The disturbed sites are represented by geometric shapes in the graph. The closer the sites are to each other, the more similar they are in regard to perennial plant species composition and abundance. The greater the distance between the sites on the graph, the more dissimilar they are, thus having differing species composition and abundances. The arrows projecting from the origin are the correlated environmental variables and are indicative of the direction and proportion of maximum change of the environmental variable (Kent and Coker, 1992). The greater the length of the arrow, the greater the amount of change in the environmental variable for that direction (thus, the arrow can be projected backward for change in that direction) and the more highly correlated that variable is to the site ordination. If lines are drawn perpendicular from the projection of a particular environmental variable arrow toward each of the sites, the sites having perpendiculars close to or past the end of the environmental variable arrow are more closely correlated to that variable. The variability in disturbed sites in relation to the dominant environmental variables can be seen in the CCA biplot. A portion of the sites were correlated to low elevations with high soil potassium and sand content (e.g. sites 1, 35, 39, 40, and 56). Other sites were highly correlated with high elevations and compacted soils (e.g. sites 8, 13, and 10). 


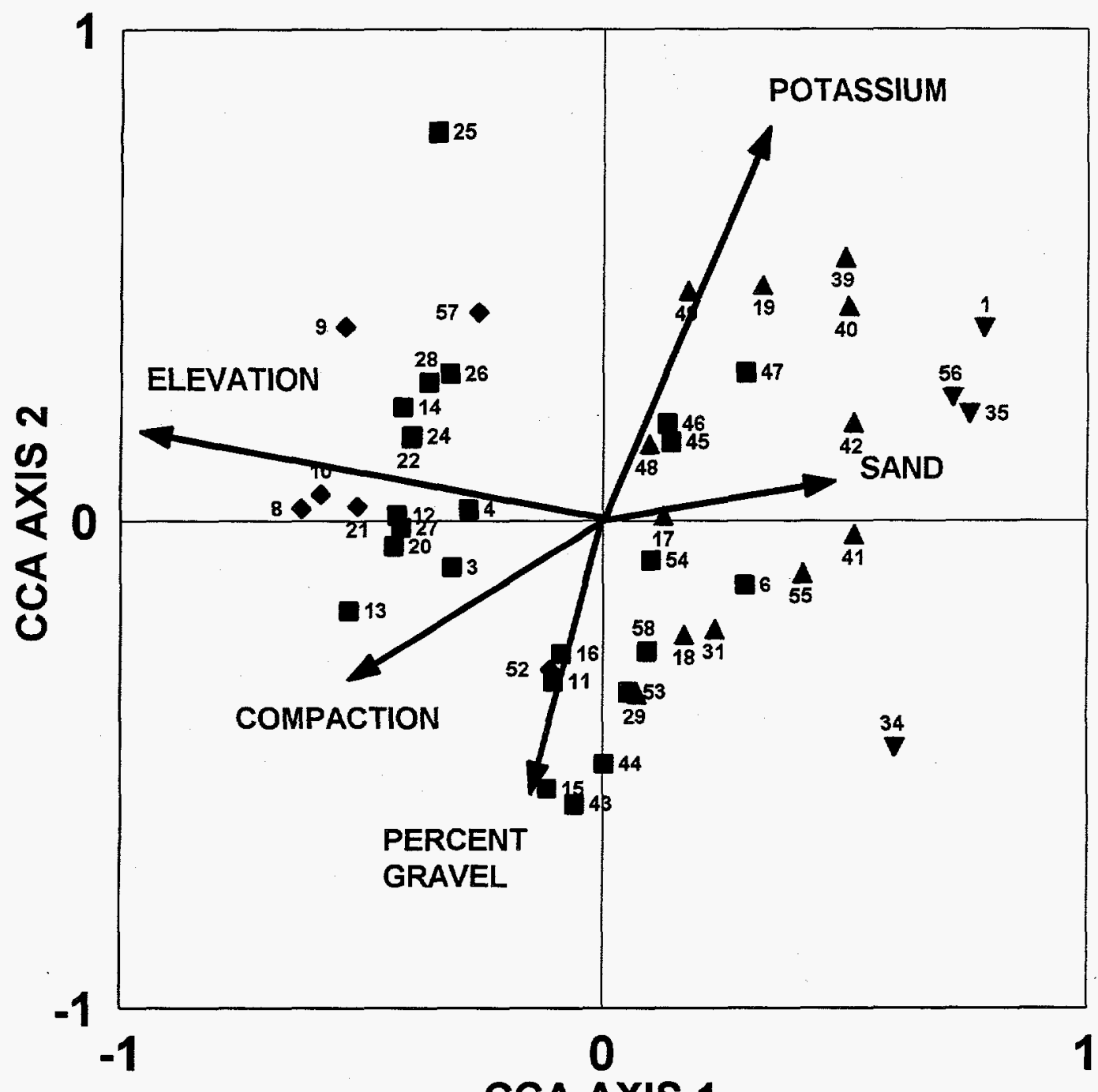

CCA AXIS 1

\section{$\triangle$ LLG $\bullet$ COL $\nabla$ LA $\bullet L G$}

Figure 12. Canonical correspondence analysis (CCA) biplot for disturbed sites and significant environmental variables for Yucca Mountain, NV. Sites are classified by the vegetation association in which they occurred (Larrea-LyciumGrayia $=$ LLG, Coleogyne $=$ COL, Larrea-Ambrosia $=$ LA, and Lycium-Grayia $=\mathrm{LG})$. For location of the sites, see Figure 3 . 


\subsubsection{SPECIES CHARACTERISTICS}

The influence of environmental variables on the plant species ordination is presented in Figure 13. The influence of a particular variable on a species can be interpreted the same as described above for sites. Acamptopappus shockleyi, L. andersonii, L. tridentata, and A. dumosa occupied disturbed sites at low elevations, with sandy soils having relatively high potassium. In contrast, $C$. ramosissima, Artemisia spinescens, Haplopappus linearifolius, Machaeranthera canescens, and $A$. canescens, inhabited disturbed sites at higher elevations having low percentages of sand and potassium in the soil. Brickellia watsonii, Erioneuron pulchellum, Lepidium fremontii, and Chrysothamnus nauseosus were more prevalent on disturbed sites having high percentages of gravel $>2 \mathrm{~mm}$, low soil penetrability, and low soil potassium (Figure 13). Delphinium parishii and Psorothamnus fremontii occupied disturbed sites having high percentages of sand and potassium in the soil, high soil penetrability and small amounts of gravel. Notice that species such as $C$. teretifolius, $H$. salsola, $E$. inflatum, and $S$. pauciflora that had relatively high cover values in the disturbed areas (Figure 8 ) are clustered near the origin. This may indicate that these species occur in a variety of disturbances, and are not strongly influenced by a particular environmental variable.

The environmental variables presented in Figures 12 and 13 were by no means the only variables influencing species composition and abundance on disturbed sites. These environmental variables were correlated with other variables (see Appendix Table 2); however, those shown in the diagrams had the highest correlations with the species and site CCA ordinations.

\subsection{CHARACTERISTICS OF DISTURBANCES WITHIN VEGETATION ASSOCIATIONS}

The influence of environmental variables on site species composition and mean cover was highly variable among sites (Figure 12). Because of this high variability, characteristics of disturbances at Yucca Mountain are not equal and cannot be treated as such when planning revegetation. Because much of the vegetation work at Yucca Mountain has been conducted on a vegetation association scale, it may be appropriate to examine disturbance characteristics within vegetation associations. Vegetation associations are plant assemblages having similar species composition and physiognomic characteristics. Vegetation associations have similar soils, moisture, and temperature regimes that have allowed similar plants species to grow and thrive. In Figure 12, the vegetation association of each site is represented. As one moves left to right on the graph, the vegetation associations generally follow the elevational gradient represented by the arrow projection. This elevational gradient integrates the soil, moisture, and temperature differences that exist as one moves from high to low elevation, partially explaining the grouping of vegetation associations along the elevational gradient. Since the elevation/vegetation association gradient appeared to play a strong role in the species composition and abundance at disturbed sites, sites were categorized by vegetation association and CCA ordinations were conducted to determine what environmental factors influence plant species composition and abundance within the separate vegetation associations. 


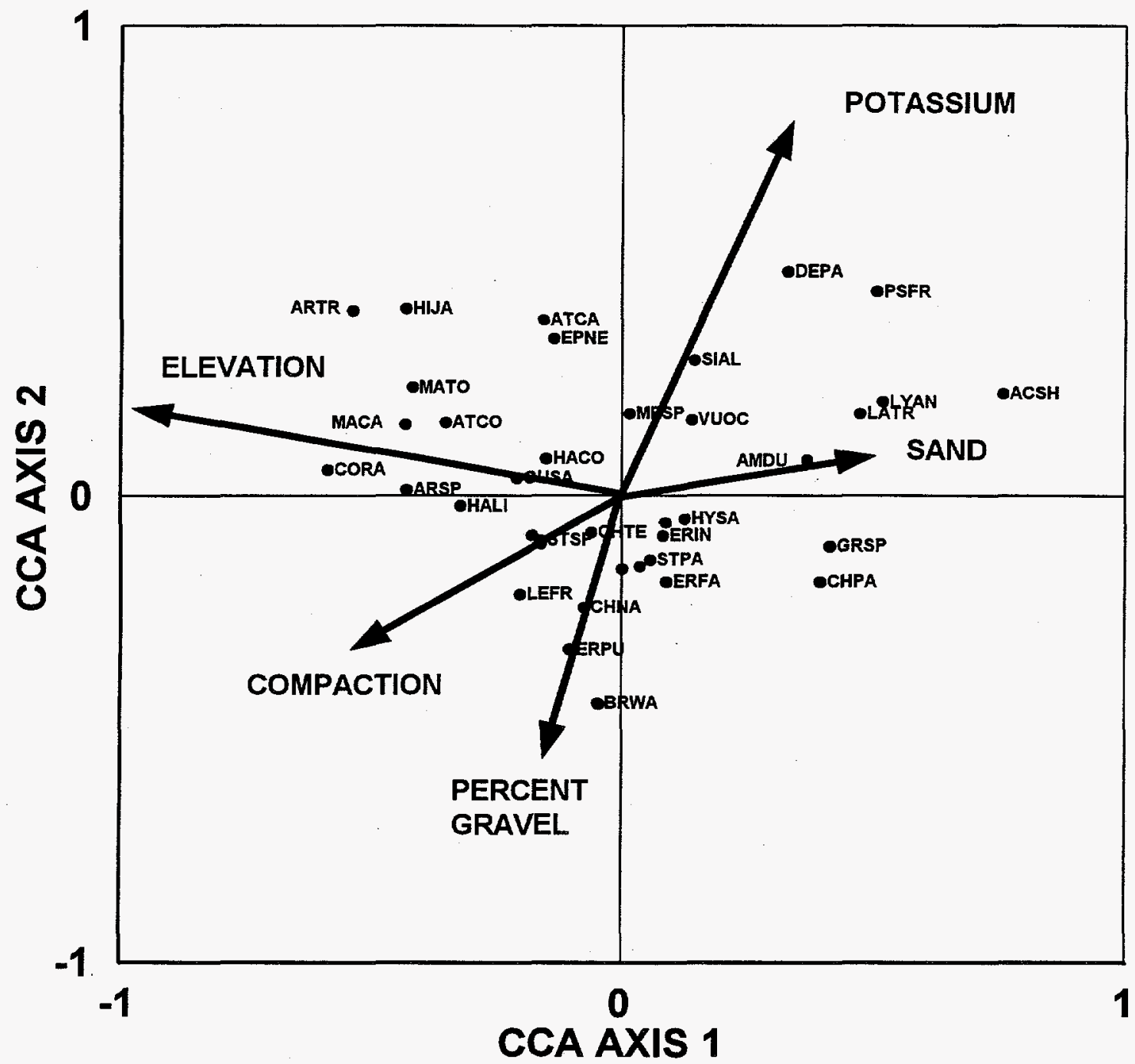

Figure 13. Canonical correspondence analysis (CCA) biplot for perennial plant species and associated significant environmental variables for disturbed sites at Yucca Mountain, NV. For explanations of species codes, see Appendix Table 1. 


\subsubsection{Lycium-Grayia Vegetation Association}

For disturbed sites where perennial cover data was collected, approximately half of the sites (25) were located in the Lycium-Grayia (LG) vegetation association. Disturbed site cover of forbs, grasses and shrubs was substantially less than that of undisturbed sites in this vegetation association (Figure 14). Bare ground, cobble, and gravel cover means were greater for the disturbed LG sites. However, plant litter was less on disturbed sites and this may be a result of the lower shrub cover on these sites (Figure 14).

Undisturbed LG sites had more perennial species present (46) than that of disturbed sites (31) (Figure 9). G. sarothrae, A. confertifolia, C. teretifolius, $A$. canescens, $C$. nauseous and $H$. salsola had the highest perennial plant cover means in the disturbed areas (Figure 15), whereas E. nevadensis, G. spinosa, L. andersonii, Eriogonum fasciculatum, Haplopappus cooperi, and $H$. salsola had the highest perennial plant cover on undisturbed sites (Figure 15). Two of these species, $G$. spinosa and $L$. andersonii, for which the vegetation association is named, were completely absent from the cover measurements at disturbed sites. Cover of $E$. nevadensis, E. fasciculatum and $H$. cooperi in the undisturbed areas was 21,38 , and 10 times greater, respectively, than the cover of these species in the disturbed LG sites.

Dominance-diversity curves (also called rank abundance diagrams) for undisturbed and disturbed LG sites are presented in Figure 16. In this study, dominance-diversity curves were used to examine the successional status of disturbed sites compared to that of undisturbed sites. If disturbed sites have comparable curves to that of undisturbed sites, then the disturbed sites are relatively close in their successional status to the undisturbed sites. If species having high cover values in the undisturbed areas are at least present in disturbed site curve, this may be an indication that the disturbed sites are on a successional trajectory towards the species composition and abundance of the undisturbed site. In Figure 16, G. sarothrae is clearly the dominant species on disturbed LG sites but is not one of the dominant species in undisturbed LG sites. A. confertifolia, $C$. teretifolius, and $A$. canescens had high cover rankings in the disturbed areas, but are found much lower in the rankings of undisturbed LG sites. $E$. nevadensis, G. spinosa, $L$. andersonii, and $E$. fasciculatum had the highest ranking cover on undisturbed sites, but had very low rankings or were completely lacking in the disturbed LG sites.

Average age of LG disturbances was $9.4( \pm 0.3)$ years. Estimated succession rates of individual species encountered on LG sites was highly variable (Table 1). Generally, species such as $G$. sarothrae, $A$. confertifolia, $C$. teretifolius, and $A$. canescens, that were dominants on the disturbed sites, had estimated succession rates of 8 to 16 years. However, species such as $E$. nevadensis and $E$. fasciculatum, that were dominants of undisturbed LG areas, had estimated succession rates of 400 to 700 years.

CCA ordination of the LG sites indicated that soil potassium, elevation, and the sum of the growing season (October to March) precipitation for the first three years after disturbance were significant environmental variables influencing species composition and abundance 


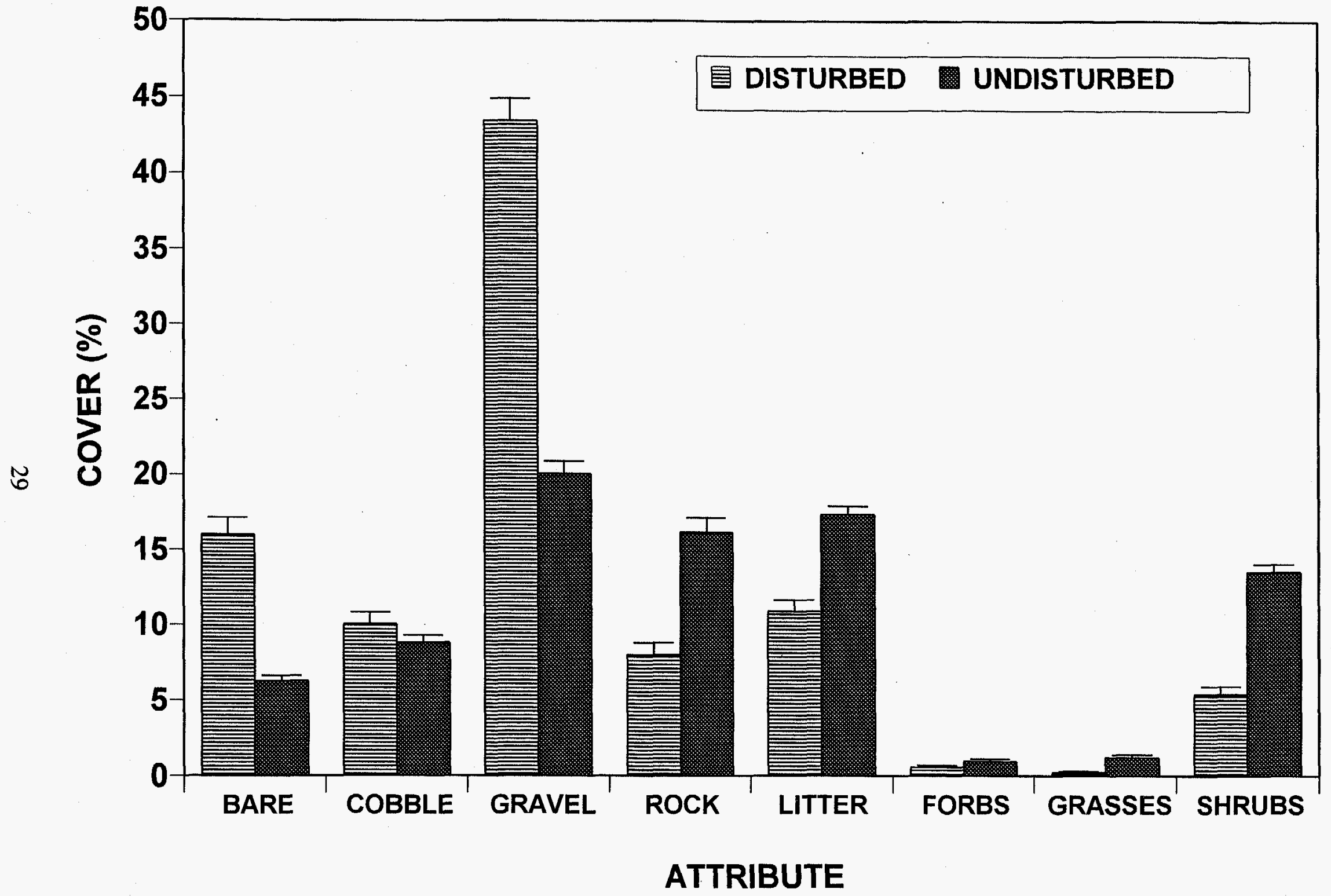

Figure 14. Mean cover attributes $( \pm$ SE) for disturbed and undisturbed sites inventoried in the Lycium-Grayia vegetation association at Yucca Mountain, NV. 


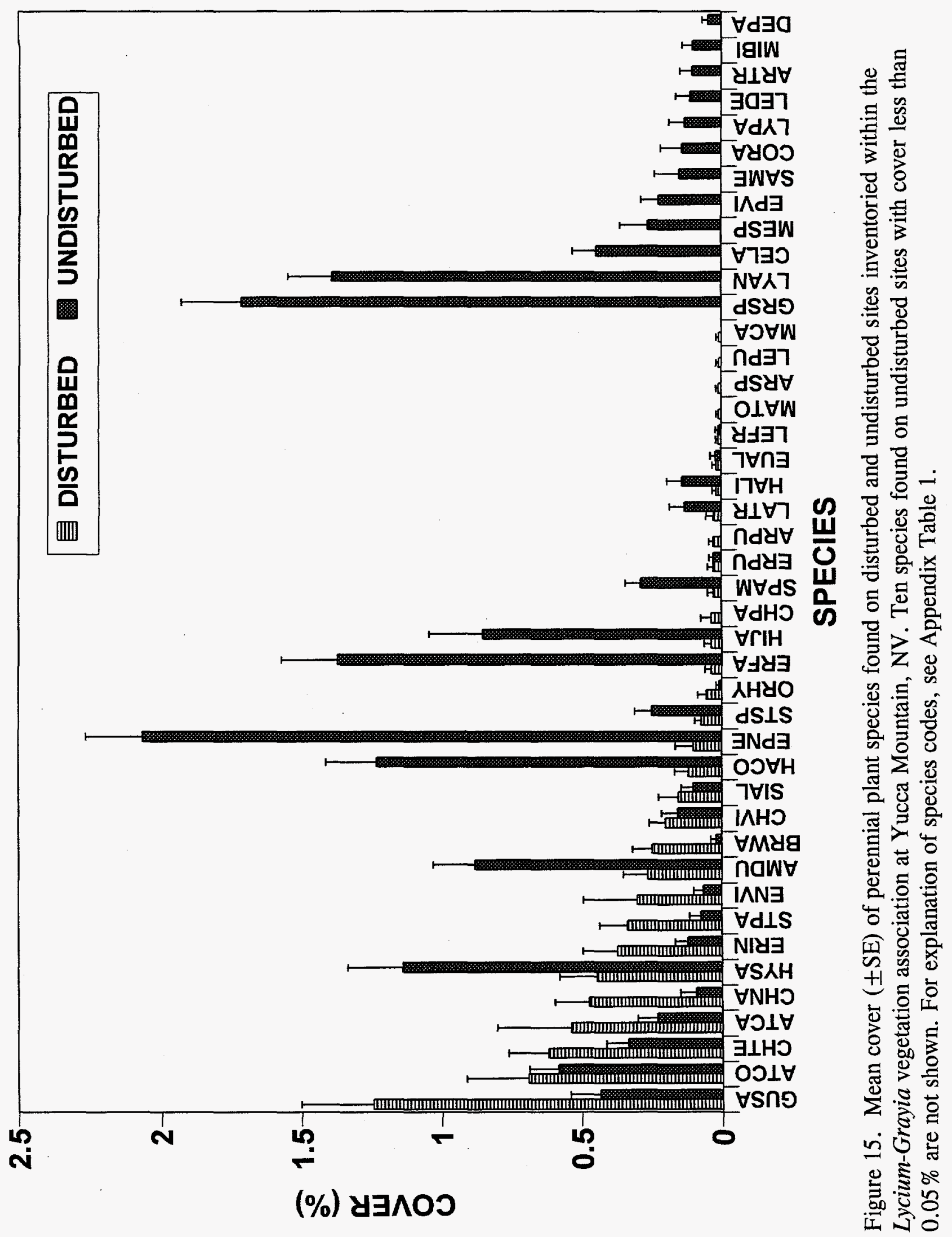




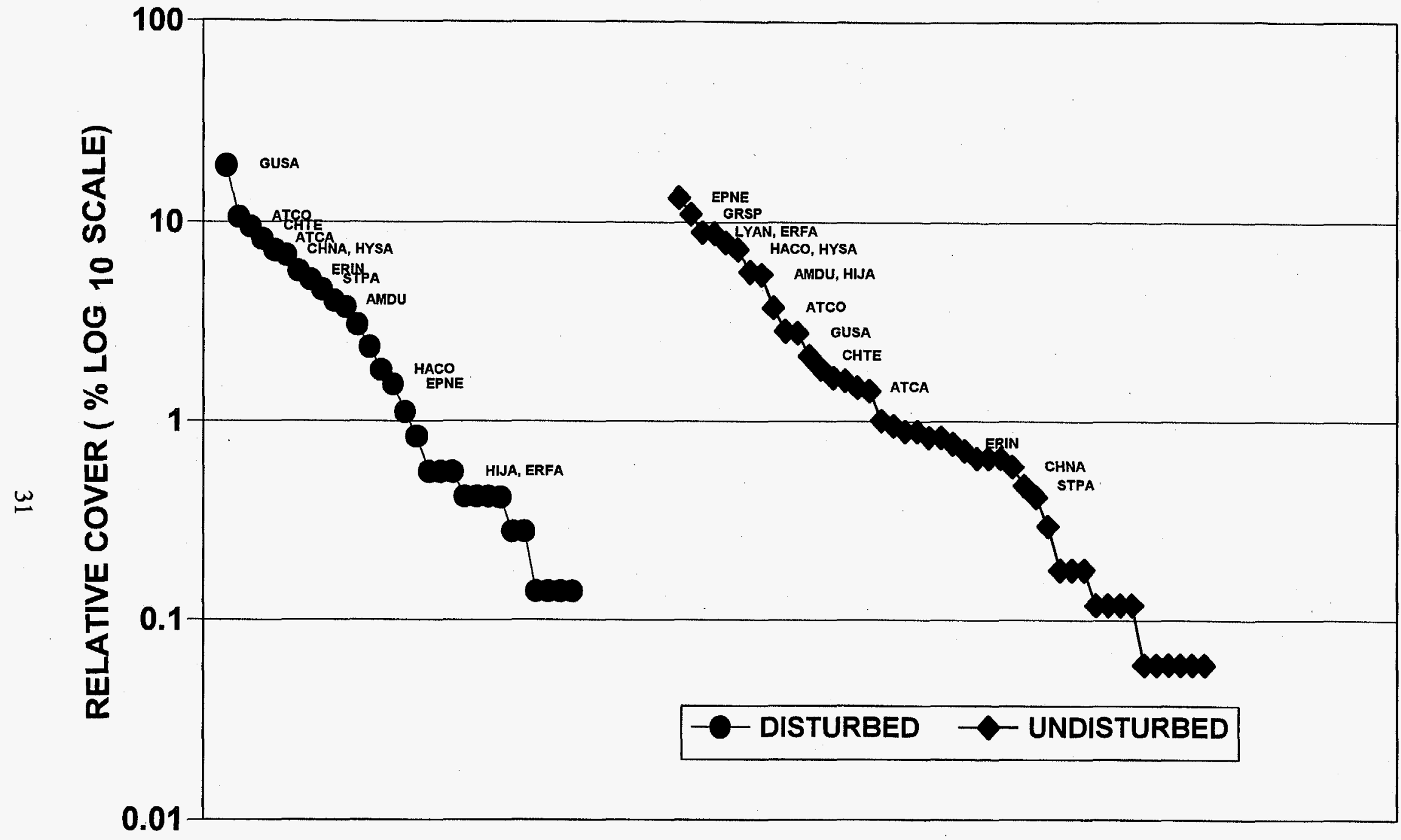

\section{SPECIES RANK}

Figure 16. Dominance-diversity curves for relative cover (\%) of perennial plant species in disturbed and undisturbed areas within the Lycium-Grayia vegetation association at Yucca Mountain, NV. Species shown were the top seven dominant species in both disturbed and undisturbed areas. For explanation of species codes, see Appendix Table 1. 
(Figure 17). As for all sites, elevation appeared to influence the LG sites even though the elevation range is much less $(1,230$ to $1,500 \mathrm{~m} ; 4,000$ to $4,880 \mathrm{ft})$ than for all sites $(1,015$ to $1,780 \mathrm{~m} ; 3,300$ to $5,800 \mathrm{ft}$ ). Apparently, the elevation range within LG sites still creates a gradient in the soil, moisture and temperature regimes. An indication of this is apparent in Figure 17. Sites that were positively correlated with elevation were negatively correlated with the precipitation variable. This may indicate that the species composition and abundance of species at the higher elevation LG sites were less dependent on precipitation for the first 3 years after disturbance. The species ordination for LG sites indicated that Hilaria jamesii, Sisymbrium altissimum, and $A$. canescens were correlated to sites having high soil potassium (Figure 17). L. tridentata was correlated to sites having greater amounts of growing season precipitation three years after disturbance. A. confertifolia, Machaeranthera tortifolia, and $A$. spinescens were correlated to high elevation sites.

\subsubsection{Larrea-Lycium-Grayia Vegetation Association}

Fourteen of the disturbed sites in this study were located in the Larrea-Lycium-Grayia (LLG) vegetation association. Average forb, grass, and shrub cover on the disturbed sites ranged from 1.6 to 2.4 times less than that measured in undisturbed LG sites (Figure 18). As with the LG sites, bare ground and gravel cover was substantially greater in the disturbed sites. In contrast to the LG sites, plant litter on LLG disturbed and undisturbed sites was comparable (Figure 18).

Perennial species richness in undisturbed LLG sites was slightly higher than that in disturbed LLG sites (Figure 9). H. salsola, C. teretifolius, L. tridentata, and A. dumosa, had the highest mean cover on the disturbed LLG sites (Figure 19). Of these, $C$. teretifolius was the only species that was not measured in the undisturbed LLG sites. L. tridentata, E. nevadensis, A. dumosa and Krameria parvifolia had the highest mean cover on undisturbed LLG sites. Mean cover of $E$. nevadensis in the undisturbed areas was 24 times greater than that in the disturbed sites and $K$. parvifolia was completely absent in the disturbed sites.

Dominance-diversity curve comparisons for disturbed and undisturbed LLG sites give an indication that species such $A$. dumosa, E. inflatum, and possibly $L$. tridentata, are approaching cover proportions similar to those on undisturbed LLG sites (Figure 20).

Succession rates for these species, based on an average age of 9.3 years for LLG disturbances, ranged between 14 and 29 years (Table 1). However, E. nevadensis ranked low in the disturbed cover rankings and had an estimated successional recovery time of 226 years. $K$. parvifolia was absent from the cover measurements (Table 1). The low ranking of $E$. nevadensis, and the high ranking of $C$. teretifolius in the disturbed sites may be an indication that these sites are not yet approaching the successional status of the undisturbed sites.

CCA ordination of LLG disturbed sites indicated that elevation, percent soil organic matter, and exchangeable sodium in the soil were statistically significant $(p=0.03)$ environmental variables (Figure 21). Again, elevation was a significant variable although the elevational range for the sites was $1,100 \mathrm{~m}(3,580 \mathrm{ft})$ to $1,315 \mathrm{~m}(4,280 \mathrm{ft})$. Apparently, this range 
a.

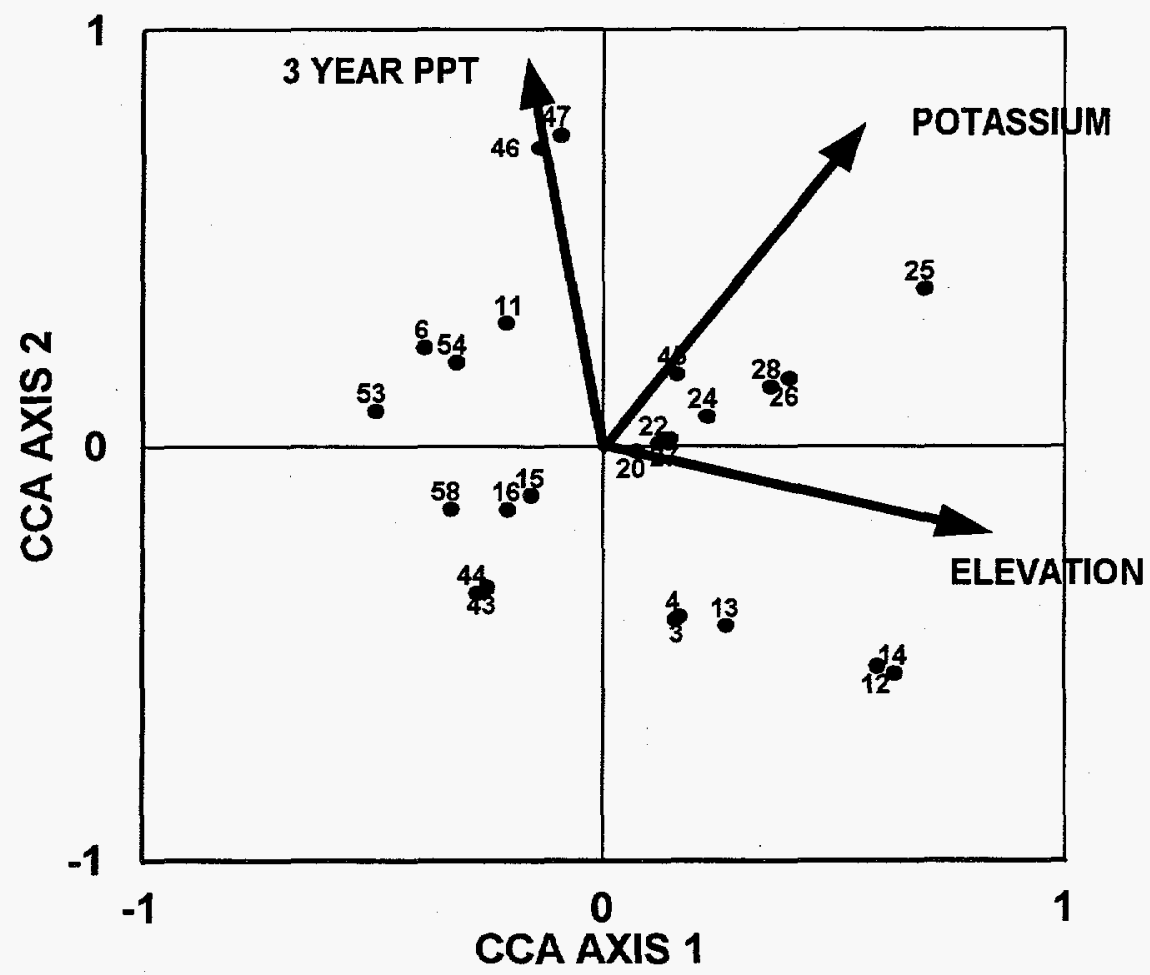

b.

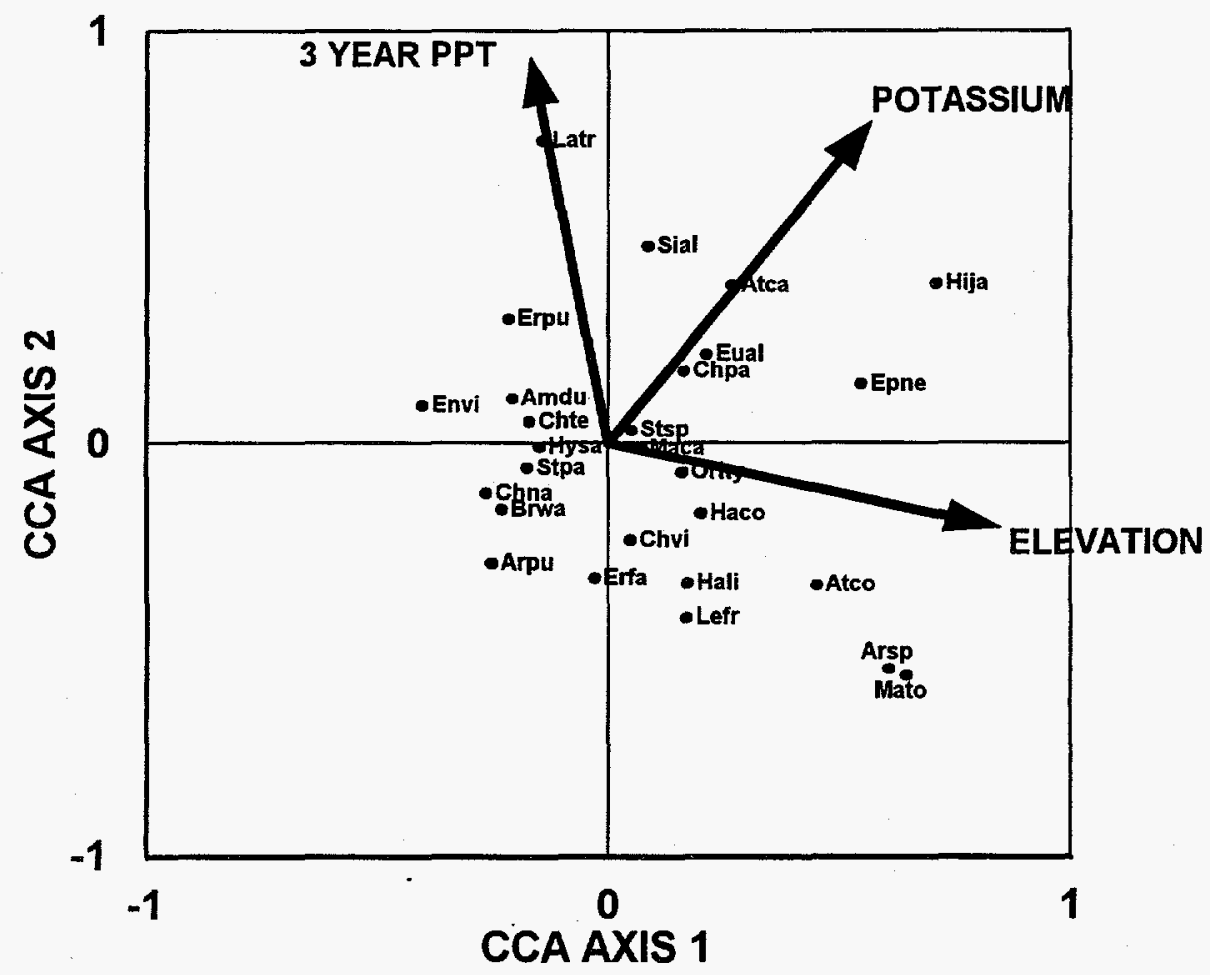

Figure 17. Canonical correspondence analysis (CCA) biplots for sites(a), perennial plant species (b) and their associated significant environmental variables for Lycium-Grayia disturbances at Yucca Mountain, NV. For site locations, see Figure 3. For explanations of species codes, see Appendix Table 1. 


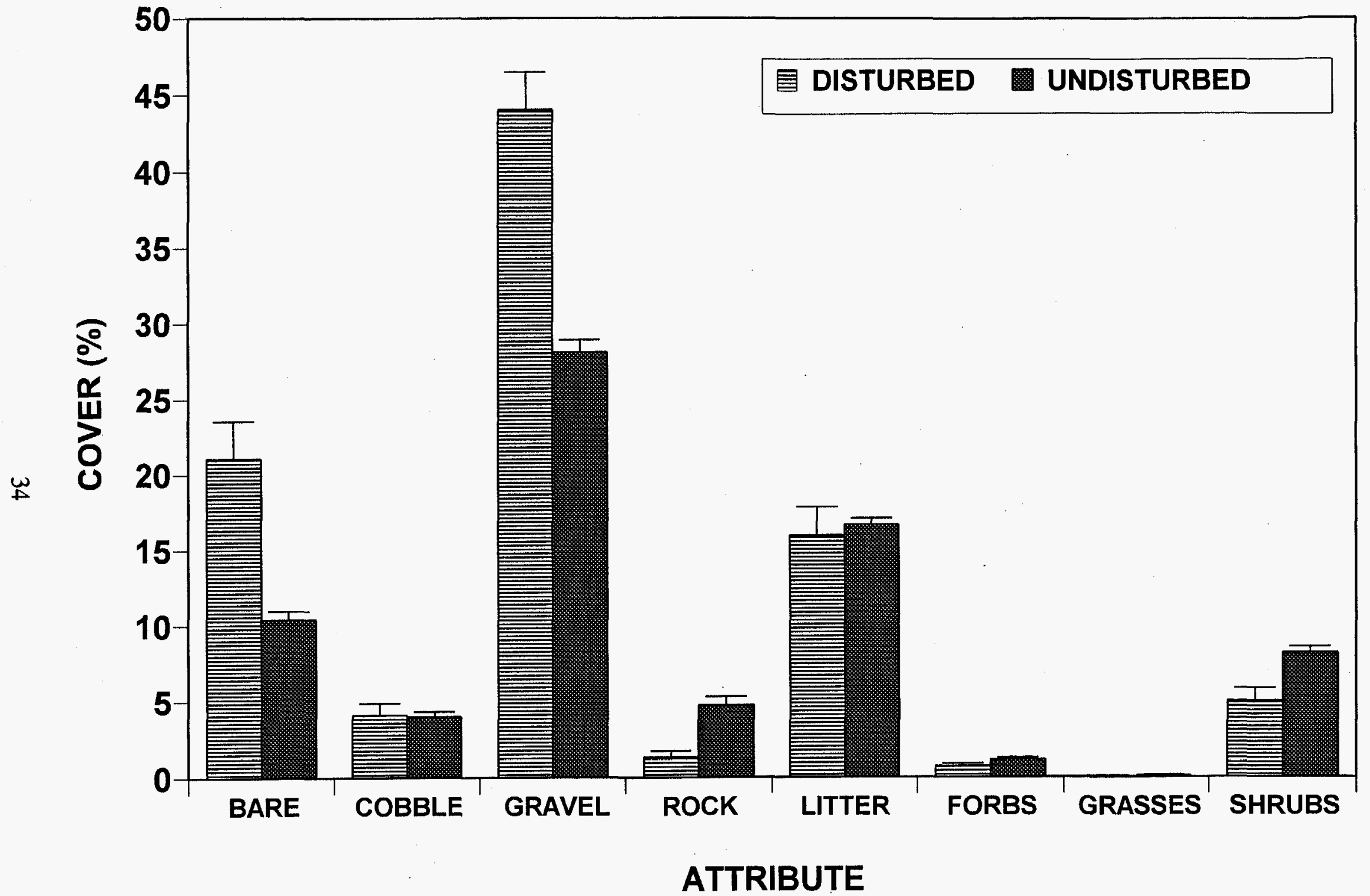

Figure 18. Mean cover attributes $( \pm \mathrm{SE})$ for disturbed and undisturbed sites inventoried in the Larrea-Lycium-Grayia vegetation association at Yucca Mountain, NV. 


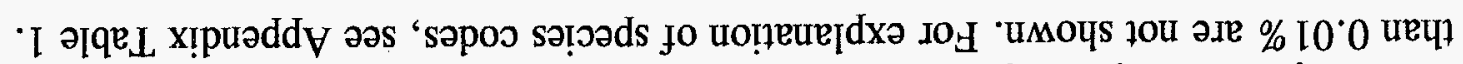

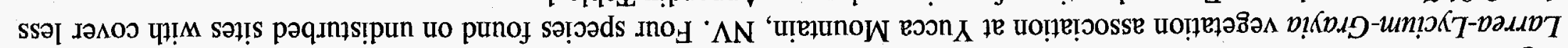

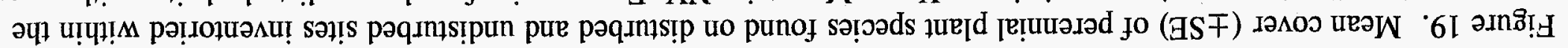

\section{SᄏI0ヨdS}

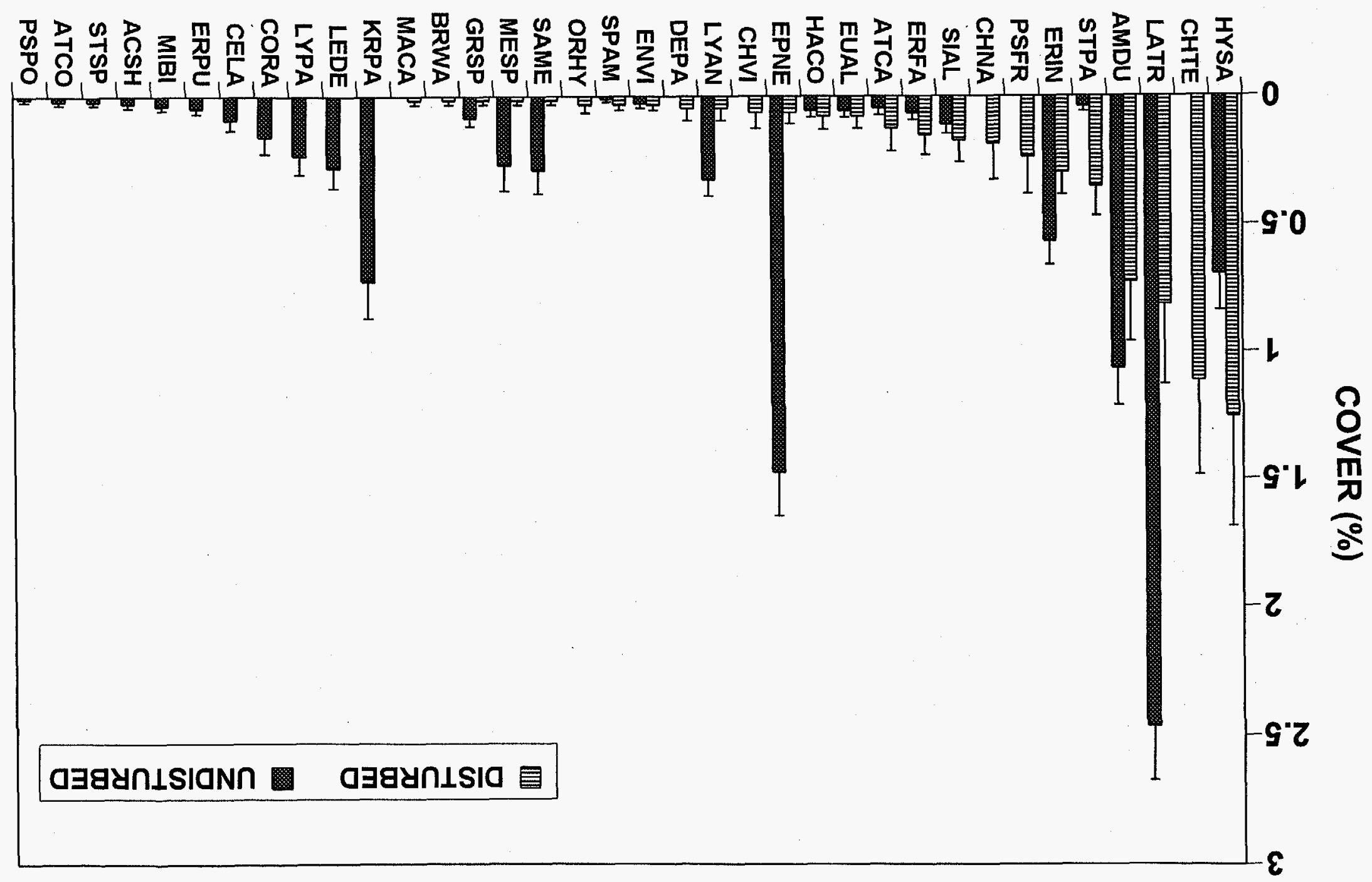




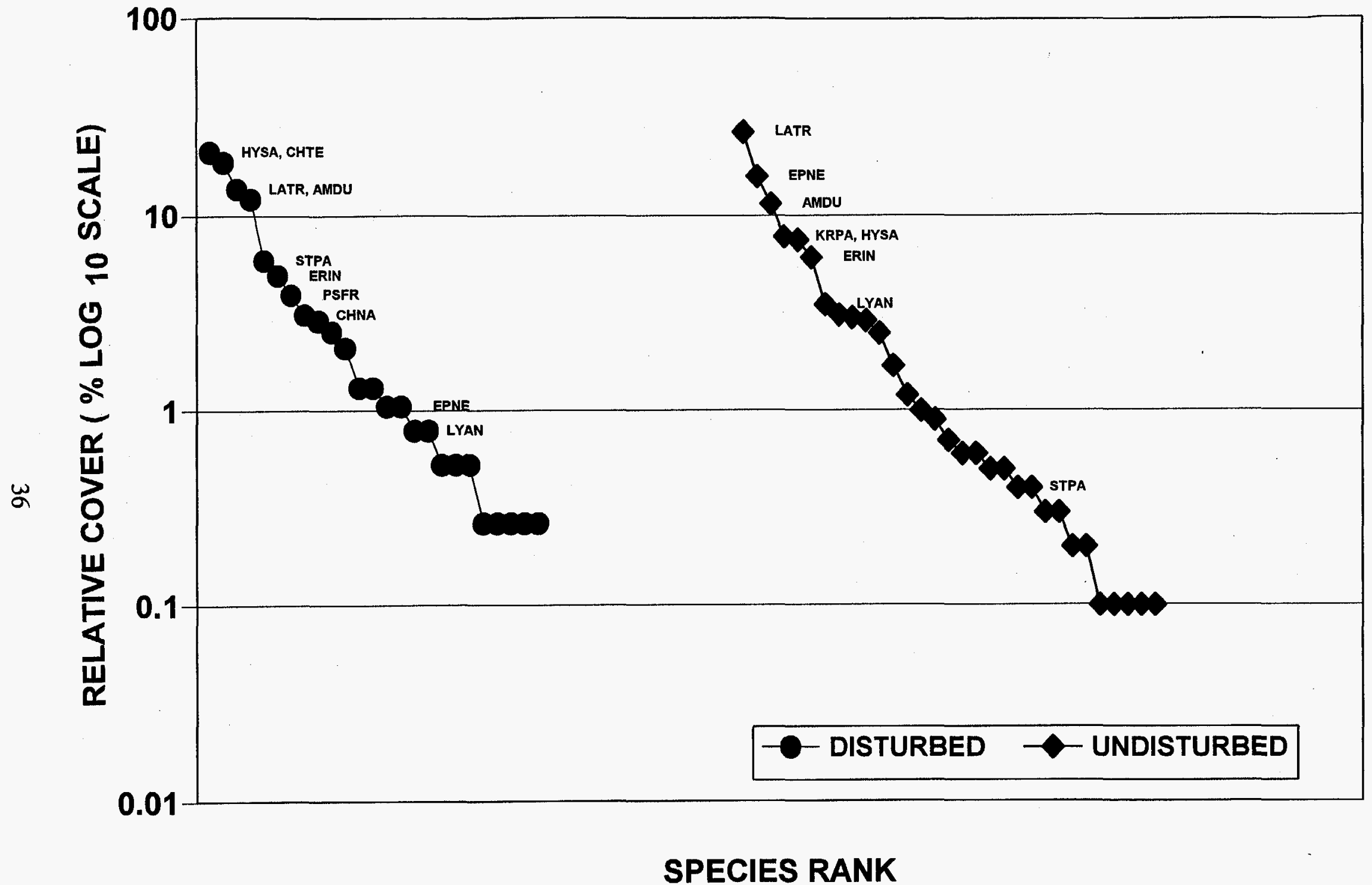

Figure 20. Dominance-diversity curves for relative cover (\%) of perennial plant species in disturbed and undisturbed areas within the Larrea-Lycium-Grayia vegetation association at Yucca Mountain, NV. Species shown were the top seven dominant species in both disturbed and undisturbed areas. For explanation of species codes, see Appendix Table 1. 
a.

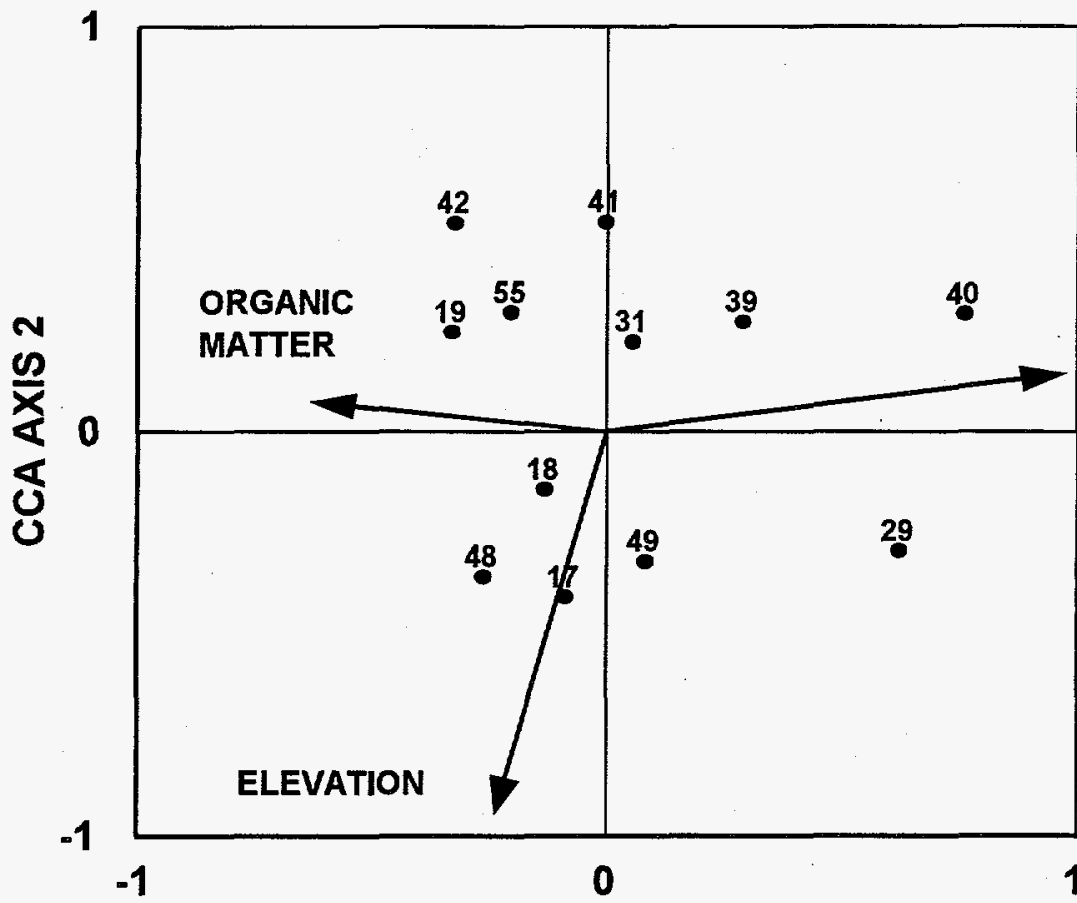

EXCH. $\mathrm{Na}$

CCA AXIS 1

b.

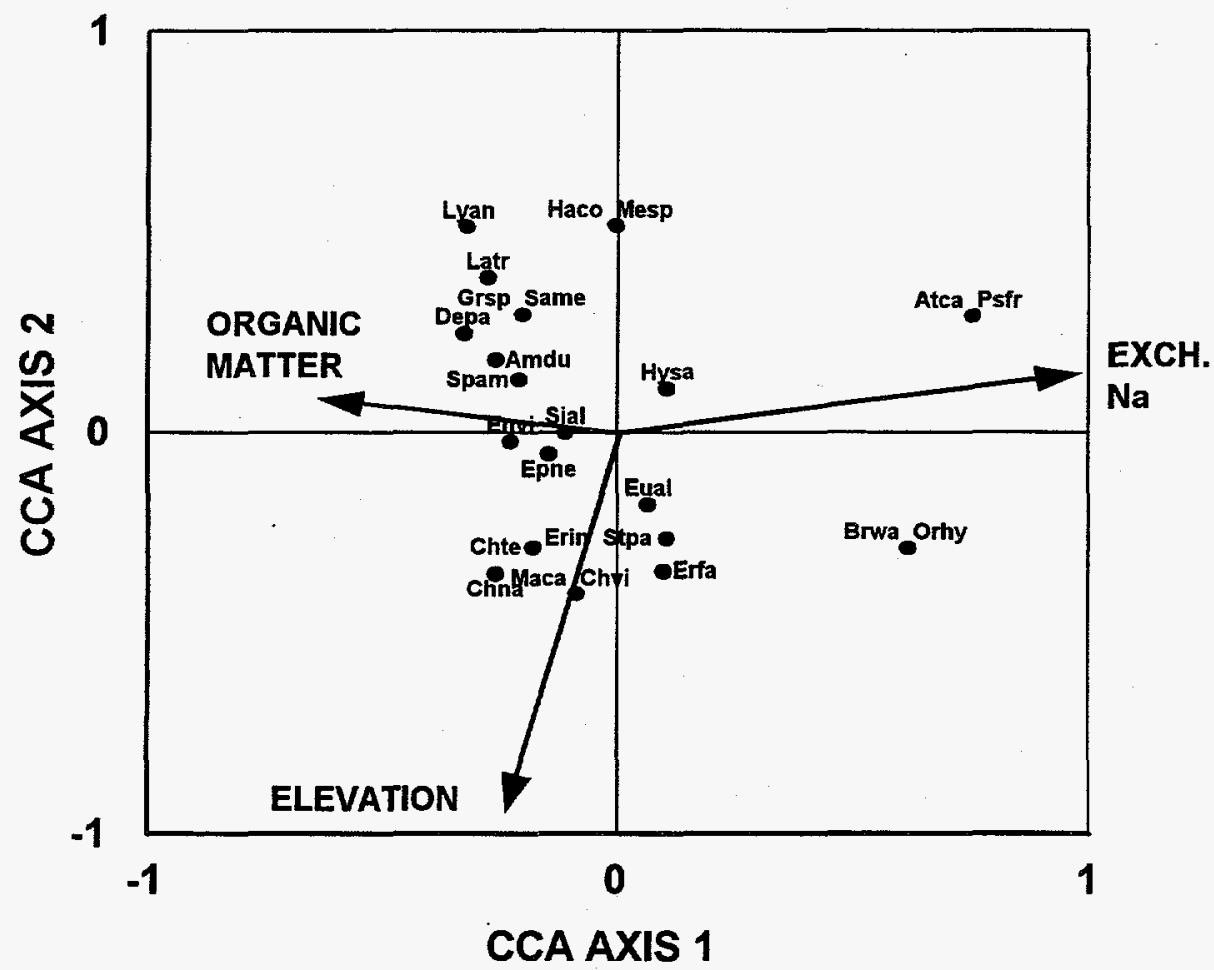

Figure 21. Canonical correspondence analysis (CCA) biplots for sites (a), perennial plant species (b) and their associated significant environmental variables for Larrea-Lycium-Grayia disturbances at Yucca Mountain, NV. For site locations, see Figure 3. For explanations of species codes, see Appendix Table 1. 
influenced the moisture and temperature regimes enough to influence the species composition and cover of these LLG sites.

The influence of organic matter may be related to site age since disturbance (as sites increase in perennial plant density and cover over time, organic matter usually increases) or that original topsoil and vegetation may have remained at the disturbed site. In this case, sites 19 and 48 (Figure 21) were plots that had higher organic matter and this may be because these sites had crushed vegetation and little or no topsoil removed. The topsoil and remaining vegetation at these sites may have influenced the positive correlation of perennial plant cover with organic matter.

Sites 29 and 40 were correlated to exchangeable sodium. High amounts of exchangeable sodium in the soil are generally undesirable to many plants. However, plants such Atriplex spp. are adapted to high amounts of sodium in the soil. The species ordination for the LLG sites indicated that $A$. canescens was correlated to the exchangeable sodium in the soil (Figure 21). High soil sodium may also be detrimental to plant establishment. Sites 50 and 51 (not shown in Figure 21) had high exchangeable sodium (3.5 and 10.24\%, respectively) and had no perennial species present on the site at the time of data collection.

\subsubsection{Coleogyne Vegetation Association}

Eight of the disturbed sites sampled for perennial cover were located in the Coleogyne (COL) vegetation association. COL undisturbed areas had approximately two times more perennial plant species present than the disturbed COL sites (Figure 9). Mean forb cover in disturbed COL sites was comparable to undisturbed sites (Figure 22). Grass cover was slightly higher in the disturbed COL sites, but shrub cover was almost 3.5 times less than that of undisturbed COL sites. As with the LLG vegetation association, bare ground, cobble, and gravel cover was greater, and plant litter cover was considerably less on the disturbed COL sites (Figure 22).

$C$. teretifolius, $A$. canescens, $H$. jamesii, $H$. salsola, and $M$. canescens had the highest mean cover in the disturbed sites (Figure 23 ). Of these species, $M$. canescens was completely absent and $A$. canescens was a minor component in the undisturbed COL sites. $C$. ramosissima had the highest mean cover in undisturbed COL sites, and this cover value was almost 23 times greater than that in the disturbed areas. A. dumosa, E. nevadensis, Lycium pallidum, $K$. parvifolia, and $L$. andersonii followed $C$. ramosissima in having greater mean cover on undisturbed COL sites. With the exception of $A$. dumosa, these species were completely absent in the COL disturbed sites examined in this study.

A comparison of the dominance-diversity curves for disturbed and undisturbed COL sites gives an indication of the difference in the successional status of the disturbed and undisturbed sites (Figure 24). Although $C$. teretifolius and $A$. canescens had the highest cover values in the disturbed sites, they were not major components of the undisturbed sites. The presence of $C$. ramosissima in the disturbed sites is encouraging, but this species' ranking in the disturbed 


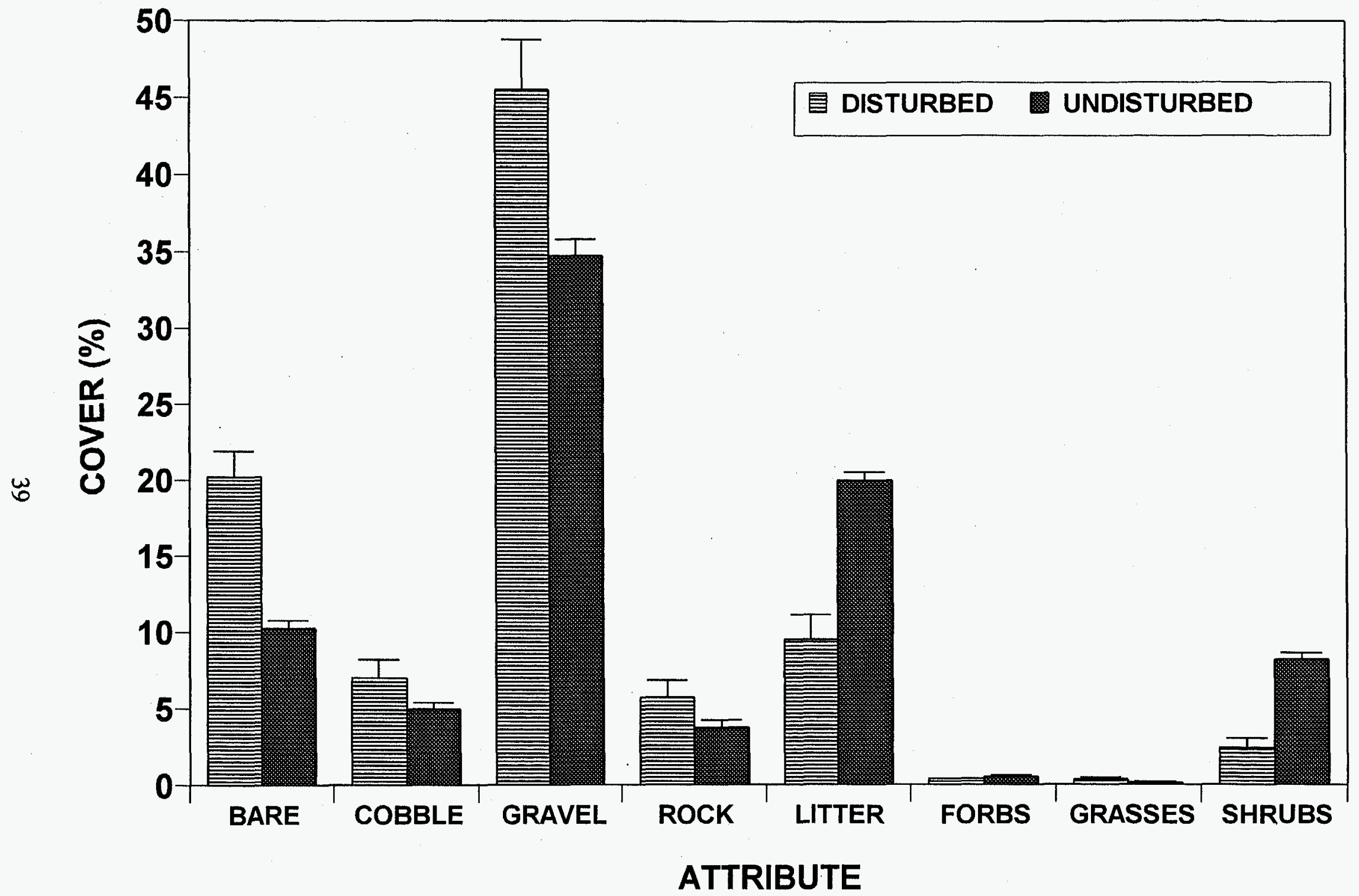

Figure 22. Mean cover attributes $( \pm \mathrm{SE})$ for disturbed and undisturbed sites inventoried in the Coleogyne vegetation association at Yucca Mountain, NV. 


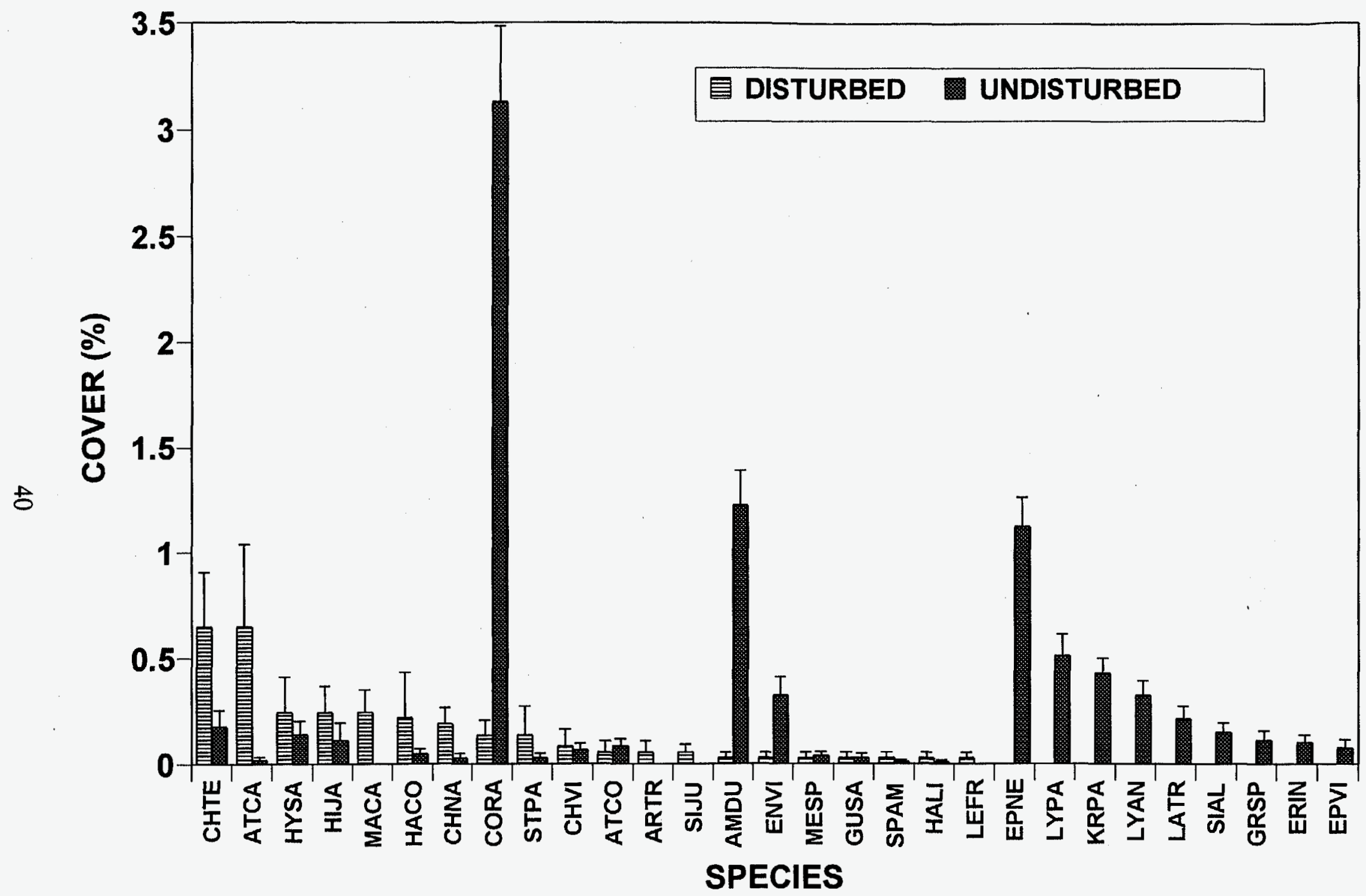

Figure 23. Mean cover $( \pm S E)$ of perennial plant species found on disturbed and undisturbed sites inventoried within the Coleogyne vegetation association at Yucca Mountain, NV. Sixteen species found on undisturbed sites with cover less than $0.05 \%$ are not shown. For explanation of species codes, see Appendix Table 1. 


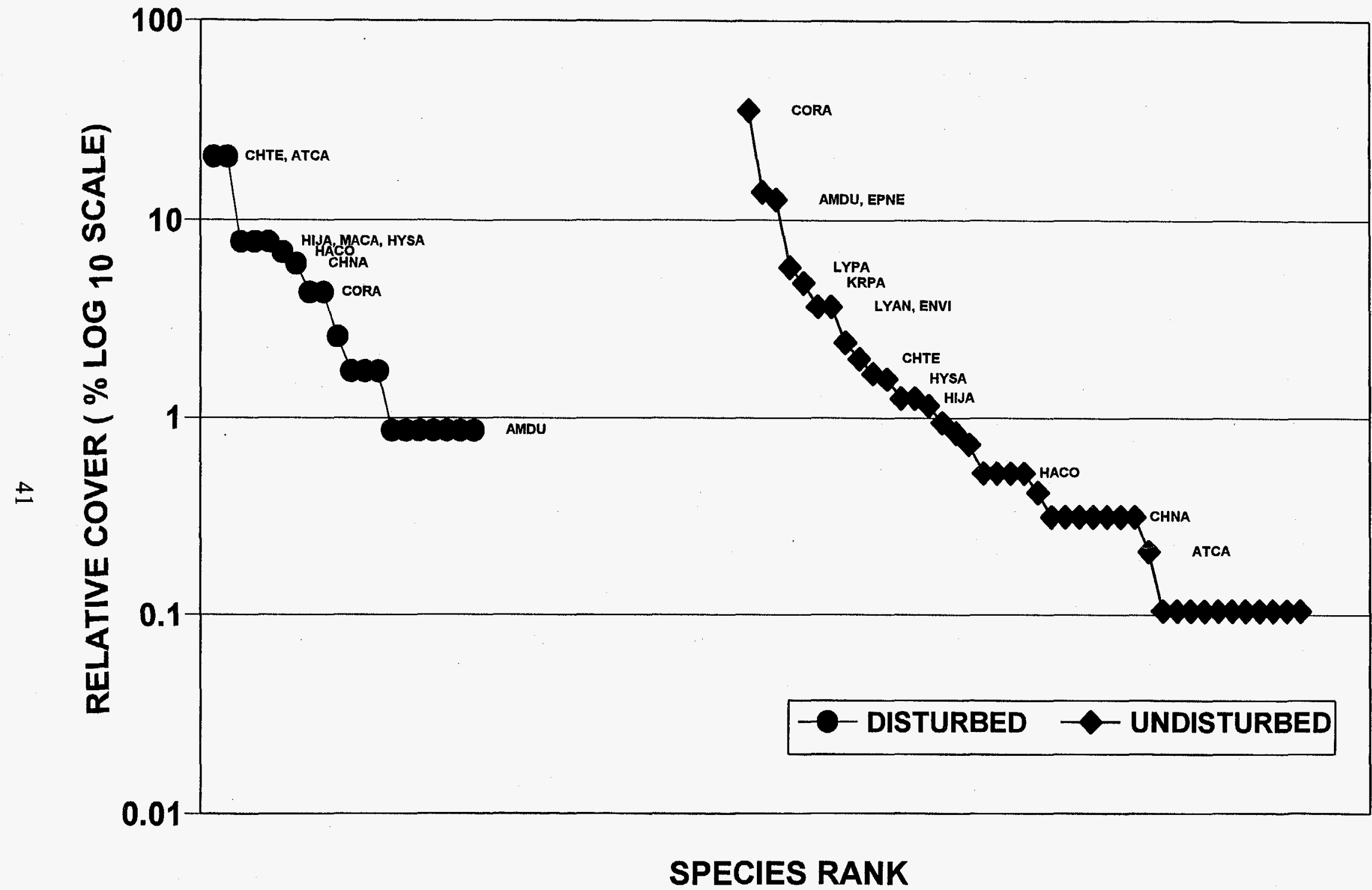

Figure 24. Dominance-diversity curves for relative cover (\%) of perennial plant species in disturbed and undisturbed areas within the Coleogyne vegetation association at Yucca Mountain, NV. Species shown were the top seven dominant species in both disturbed and undisturbed areas. For explanation of species codes, see Appendix Table 1. 
site cover values is low when compared to undisturbed COL sites. Estimated successional recovery time for the two undisturbed site dominants, $C$. ramosissima and $A$. dumosa, based on an average disturbed site age of 10.4 ( $\pm 0.3 \mathrm{SD}$ ) years, was 241 years and 471 , respectively (Table 1 ). The absence of $L$. pallidum, $L$. andersonii, $K$. parvifolia, and especially $E$. nevadensis from the disturbed site cover may be an indication that the successional status of the disturbed COL sites will take more than 400 years to approach that of the undisturbed sites.

CCA ordination was conducted on the COL disturbed site perennial cover and environmental variables. Because of the low number of sites for this vegetation association, the analysis was not statistically significant. Therefore, no results will be presented.

\subsubsection{Larrea-Ambrosia Vegetation Association}

Four of the disturbed sites sampled for perennial cover occurred in the Larrea-Ambrosia (LA) vegetation association. These disturbed sites had average forb and grass cover that was comparable to the undisturbed sites (Figure 25). Gravel, rock, and cobble cover was substantially greater in the disturbed LA sites; however, bare ground cover was less than that in the undisturbed areas. As with the other vegetation associations, average shrub cover and plant litter cover were greater in the undisturbed areas.

Species richness in the LA disturbed sites was considerably less than that of undisturbed sites (Figure 9). Of the species in disturbed areas, $A$. dumosa, S. pauciflora, L. tridentata, $L$. pallidum, and Chrysothamnus paniculatus, had the highest mean cover (Figure 26). Of these species , $S$. pauciflora and $C$. paniculatus were minor components in the undisturbed sites whereas $A$. dumosa, L. tridentata, and $L$. pallidum were major components in the undisturbed areas. The other species having high mean cover values in the undisturbed areas were $M$. spinescens, $A$. shockleyi and $K$. parvifolia. These species had very low cover values or were not present in the disturbed sites sampled.

An examination of the dominance-diversity curves for disturbed and undisturbed sites provides an indication of the successional status of LA disturbed sites (Figure 27). A. dumosa was the dominant species in both the disturbed and undisturbed sites (Figure 27), and this species had an estimated recovery time of 16 years (Table 1 ). L. tridentata, L. pallidum, and Acamptopappus shockleyi, which had high cover rankings in the undisturbed LA sites (Figure 27 ) had recovery rates of 54 to 109 years (Table 1 ). However, $M$. spinescens and $E$. nevadensis did not contribute to the disturbed sites' cover (Figure 27), and this may be an indication that the successional status of these sites are quite different and may require recovery times greater than 110 years.

As with the Coleogyne vegetation association, the CCA ordination for LA sites and environmental variables was not statistically significant. Therefore, the influence of environmental variables within this vegetation association could not be determined. 


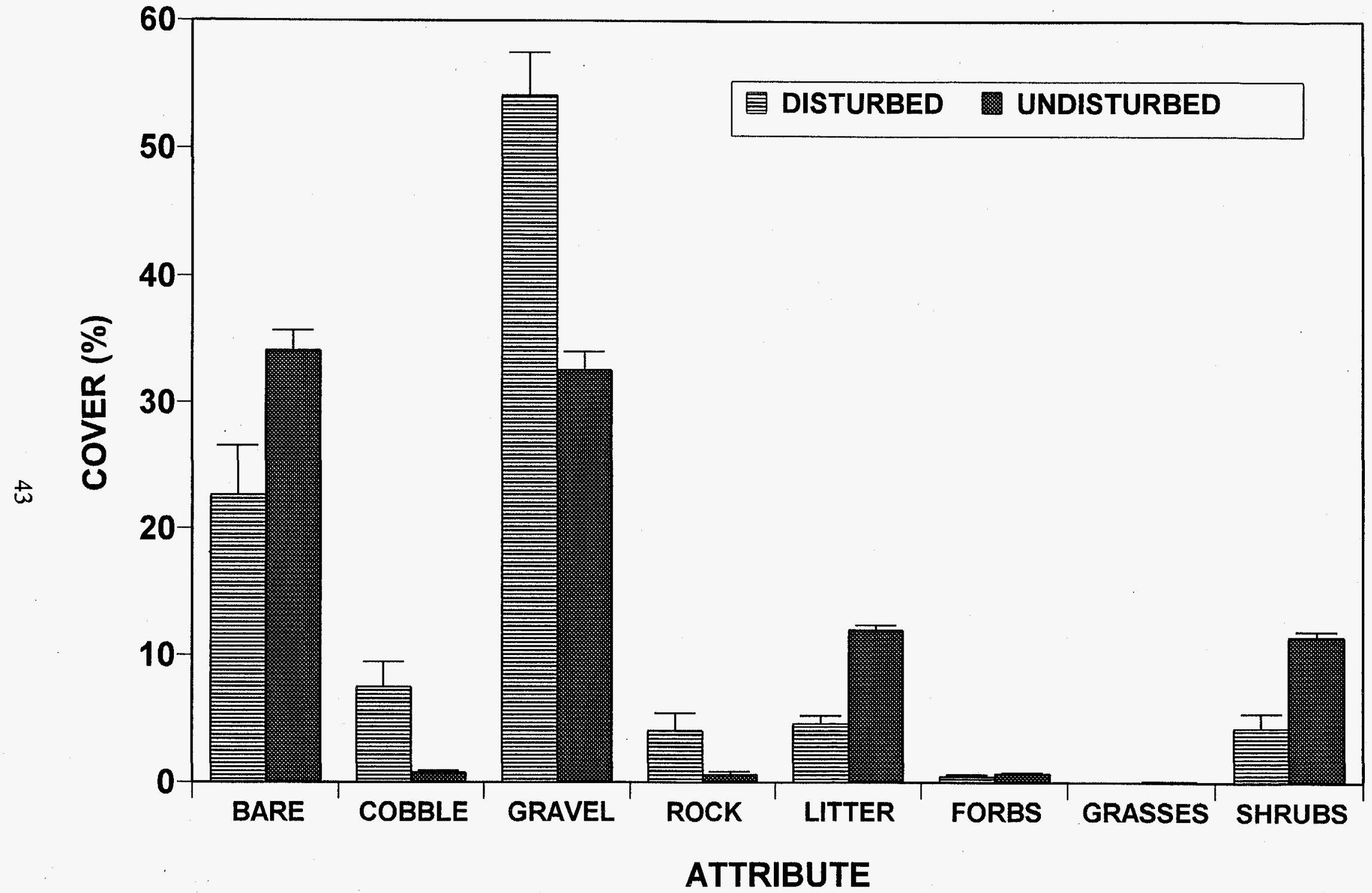

Figure 25. Mean cover attributes $( \pm \mathrm{SE})$ for disturbed and undisturbed sites inventoried in the Larrea-Ambrosia vegetation association at Yucca Mountain, NV. 


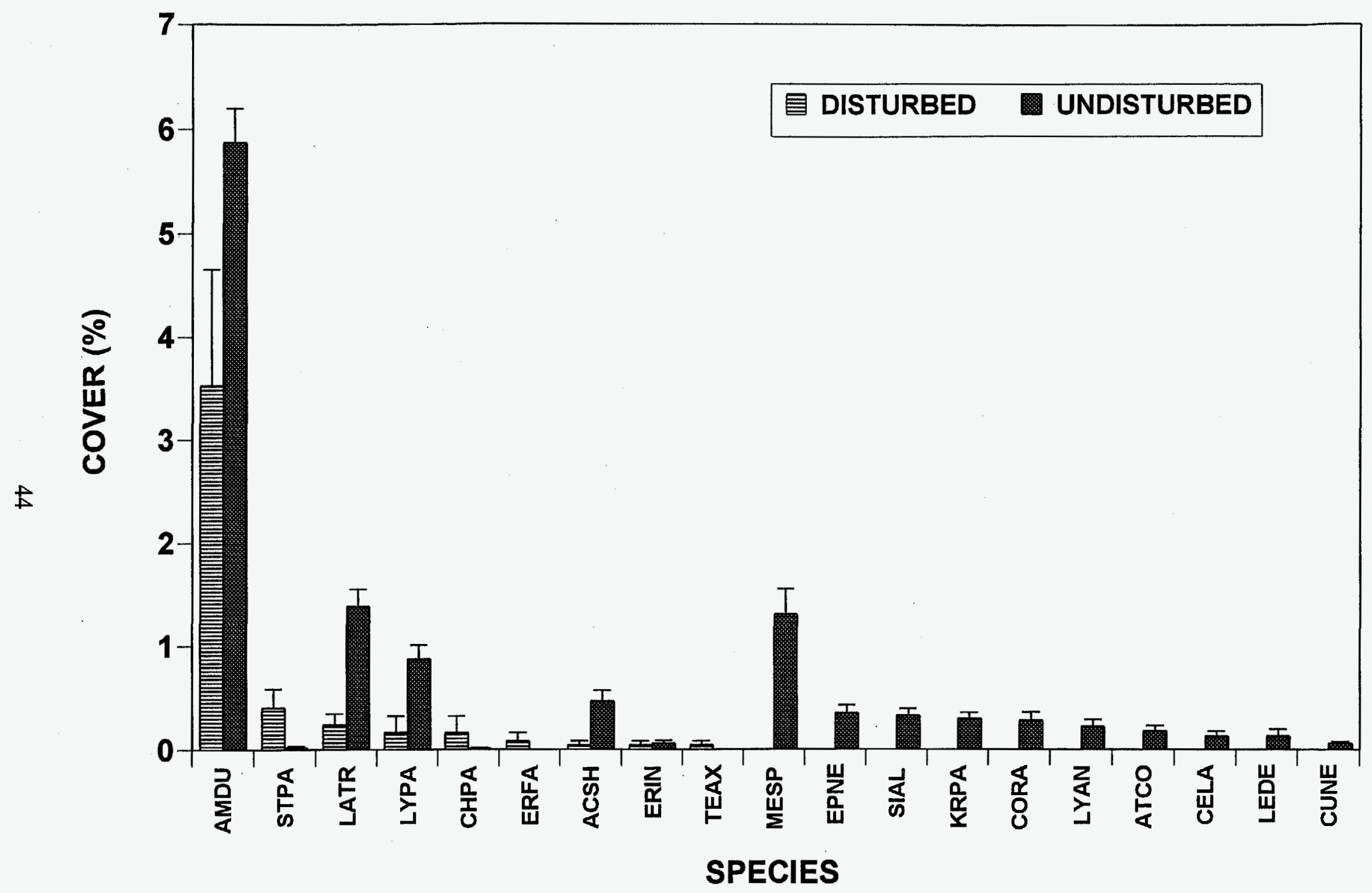

Figure 26. Mean cover $( \pm \mathrm{SE})$ of perennial plant species found on disturbed and undisturbed sites inventoried within the Larrea -Ambrosia vegetation association at Yucca Mountain, NV. Eight species found on undisturbed sites with cover less than $0.05 \%$ are not shown. For explanation of species codes, see Appendix Table 1. 


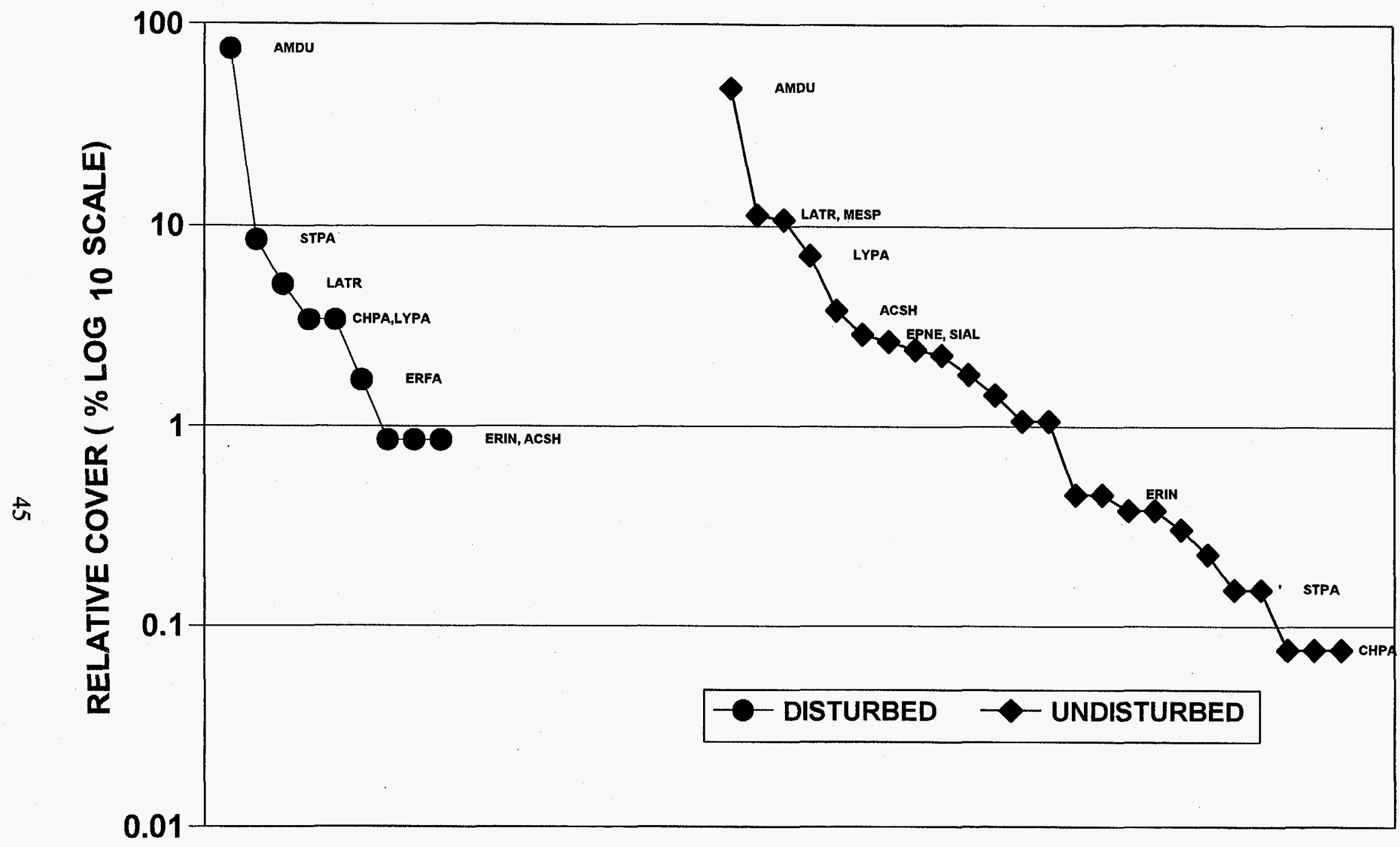

SPECIES RANK

Figure 27. Dominance diversity curves for relative cover (\%) of perennial plant species in disturbed and undisturbed areas within the Larrea -Ambrosia vegetation association at Yucca Mountain, NV. Species shown were the top eight dominant species in both disturbed and undisturbed areas. For explanation of species codes, see Appendix Table 1. 


\subsection{CHARACTERISTICS OF DISTURBANCE TYPES}

The type of disturbance (i.e. borrow area, cutslope, drill pad, etc.) may be an important factor influencing the succession on a disturbed site. For example, succession on a borrow area may be quite different than that on a cutslope just because of the differences in slope. However, in this study, differences in plant succession on disturbance types are overridden by the influences of elevation. The influence of environmental variables on all disturbed sites categorized by disturbance type is presented in Figure 28. The high variability in the locations of the various disturbance types on the graph gives an indication that elevation had a stronger influence on species composition and cover of disturbed sites than did disturbance type alone. CCA ordinations conducted for each of the disturbance types generally had the same environmental variables with high correlations as those depicted in Figure 28. However, an examination of the characteristics of disturbance types may provide information about subtle differences in the disturbances types that can aid in the development of revegetation plans for disturbed sites.

Disturbed sites were categorized into the following disturbance type categories: 1) borrow areas (areas where topsoil and subsoil were removed and used for fill material as in Figure 29a); 2) cutslopes (areas were an exposed slope was created by the removal of soil material as in Figure 29b); 3) drill pads (an area cleared of vegetation frequently having fill material brought in for leveling as in Figure 30a); and 4) vegetation crushed (areas that have had light to moderate disturbance that crushes or breaks the vegetation as in Figure $30 \mathrm{~b}$ ). Of the disturbed sites sampled for perennial cover, there were 14 borrow areas, 15 cutslopes, 11 drill pads, and 5 crushed vegetation sites.

Forb and grass cover was not significantly different among disturbance types and was comparable to that of the undisturbed sites (mean of all undisturbed sites) (Figure 31). Sites with vegetation crushed had significantly greater shrub cover over other disturbance types and this was comparable to the undisturbed area. Drill pads had significantly greater annual plant cover when compared to the other disturbance types; however, this value was lower than that for annual cover on undisturbed areas. Gravel cover was not significantly different among sites but was considerably greater than that of undisturbed sites.

Of the disturbance types, borrow areas had the greatest species richness; however, these values were less than that for undisturbed areas (Figure 32). Species richness was the lowest for vegetation crushed sites. Dominance-diversity curves for the disturbance types and undisturbed areas indicate differences among the disturbance types in species composition and relative cover (Figure 33). In borrow areas, $A$. canescens and $C$. teretifolius were the dominant species. On cutslopes, $G$. sarothrae and $A$. confertifolia had the highest relative cover. $E$. inflatum, G. sarothrae, A. canescens, S. altissimum, and C. teretifolius were major component of cover on drill pads. On areas where vegetation was crushed, $A$. dumosa was dominant, followed by $C$. teretifolius. With the exception of $A$. dumosa, the above species were not major dominants in undisturbed sites. 


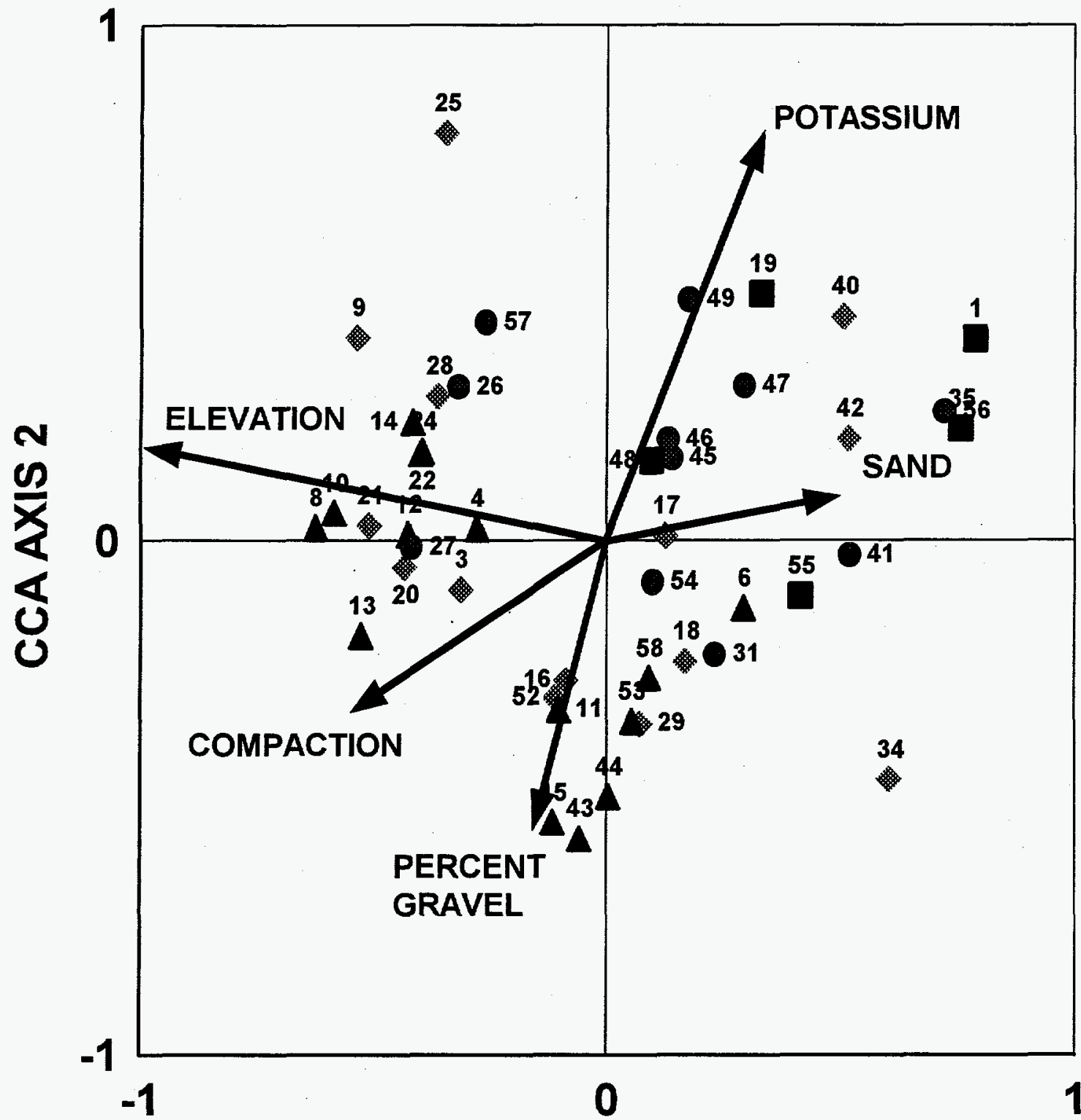

CCA AXIS 1

BORROW $\triangle$ CUTSLOPE 9 PAD $\square$ VEGCRUSH

Figure 28. Canonical correspondence analysis (CCA) biplot for disturbed sites and significant environmental variables for Yucca Mountain, NV. Sites are classified by the following disturbance types: borrow areas (BORROW), cutslopes (CUTSLOPE), drill pads (PAD), and areas with crushed vegetation (VEGCRUSH). For location of the sites, see figure 3. 


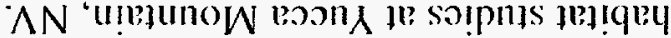

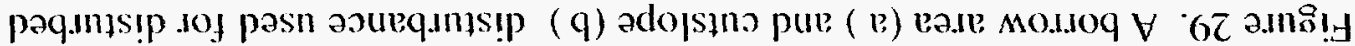
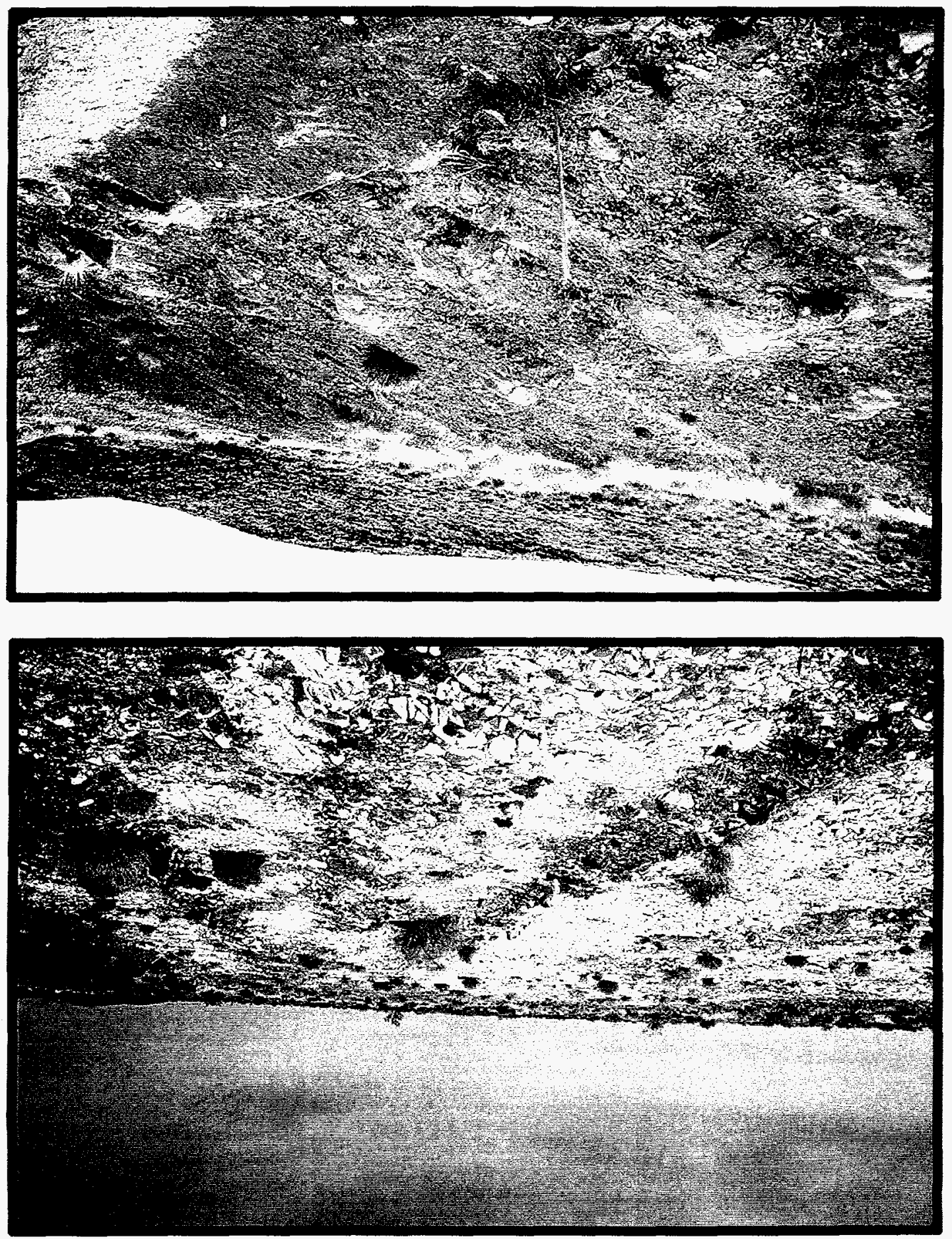
a.

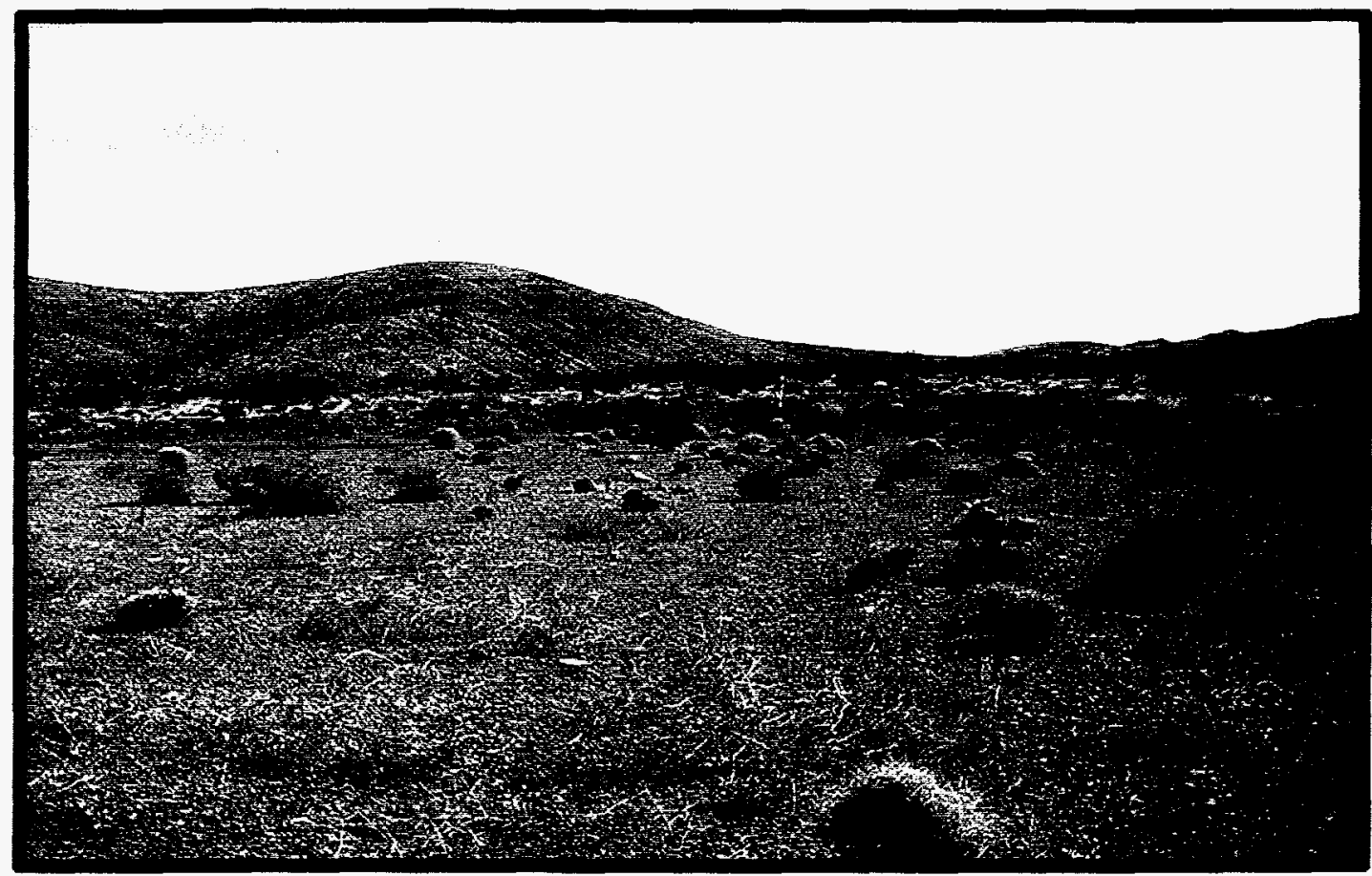

b.

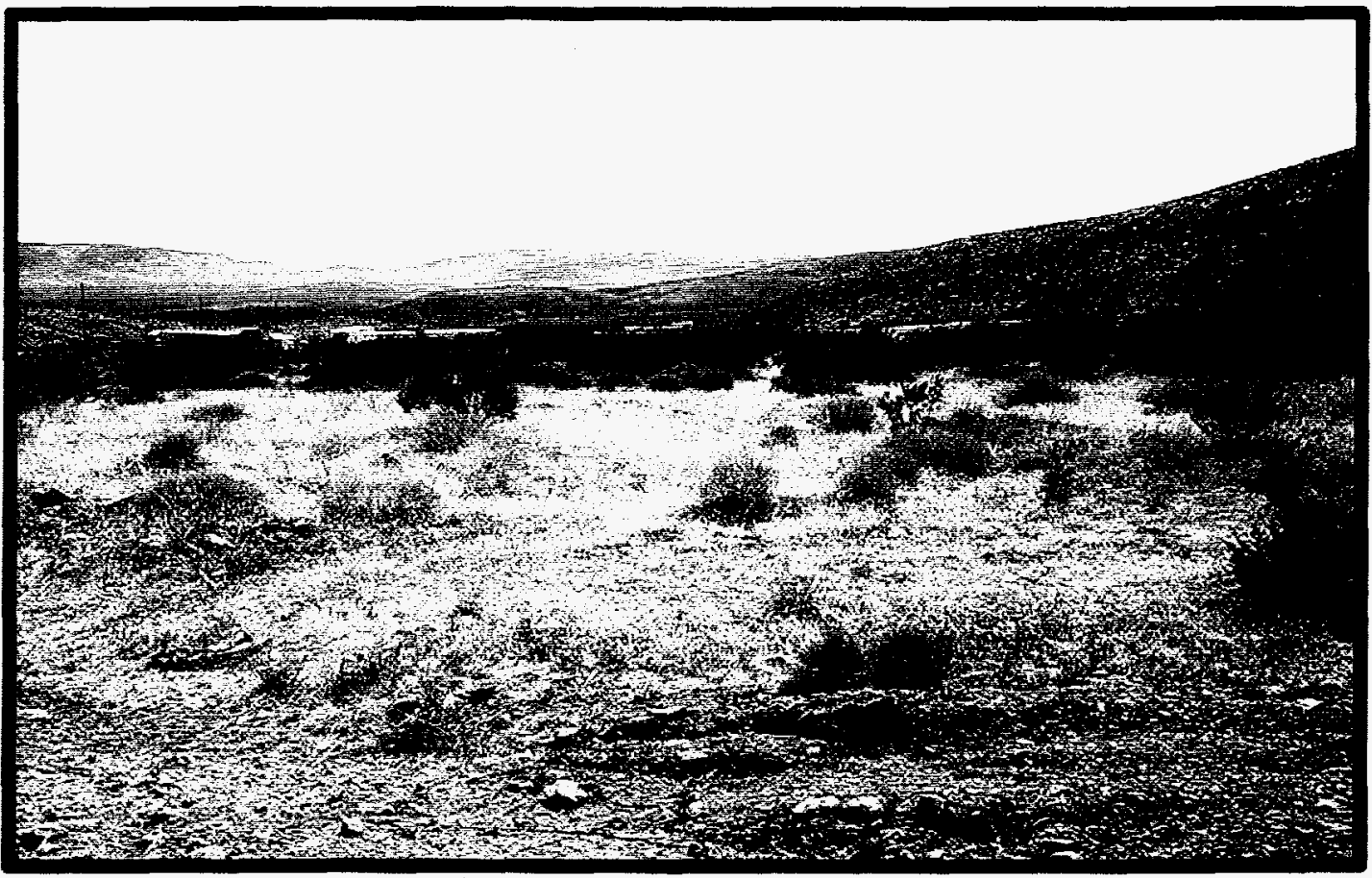

Figure 30. A drill pad (a ) and a crushed vegetation disturbance (b) used for disturbed habitat studies at Yucca Mountain, NV. 


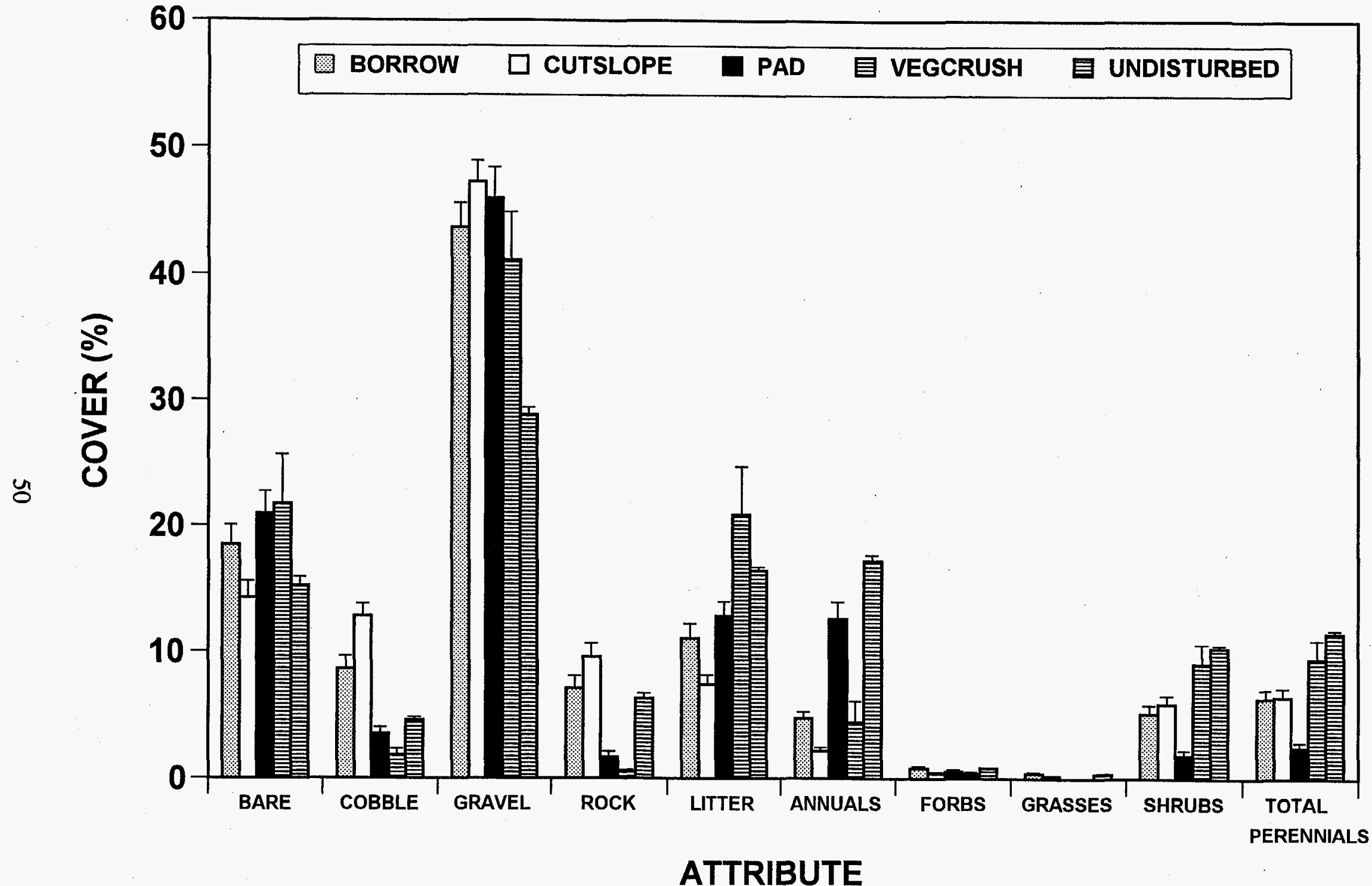

Figure 31. Mean cover attributes $( \pm \mathrm{SE})$ for disturbance types and undisturbed sites inventoried for the disturbed habitat studies at Yucca Mountain, NV. The disturbance types were as follows: borrow areas (BORROW), cutslopes (CUTSLOPE), drill pads (PAD), and areas with crushed vegetations (VEGCRUSH). 


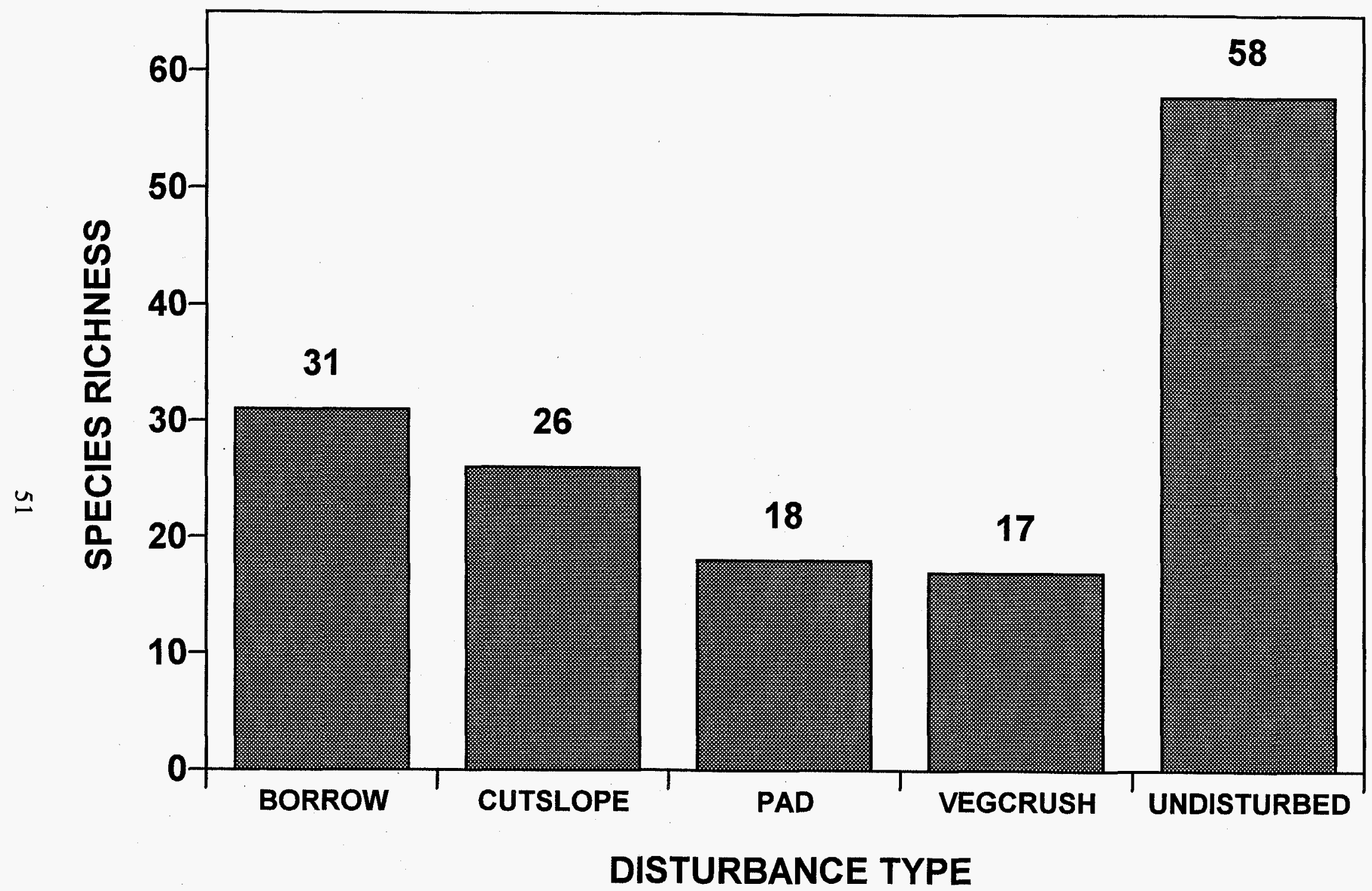

Figure 32. Species richness (number) of perennial plant species found in disturbance types and undisturbed sites at Yucca Mountain, NV. The disturbance types were as follows: borrow areas (BORROW), cutslopes (CUTSLOPE), drill pads (PAD), and areas with crushed vegetation (VEGCRUSH). 


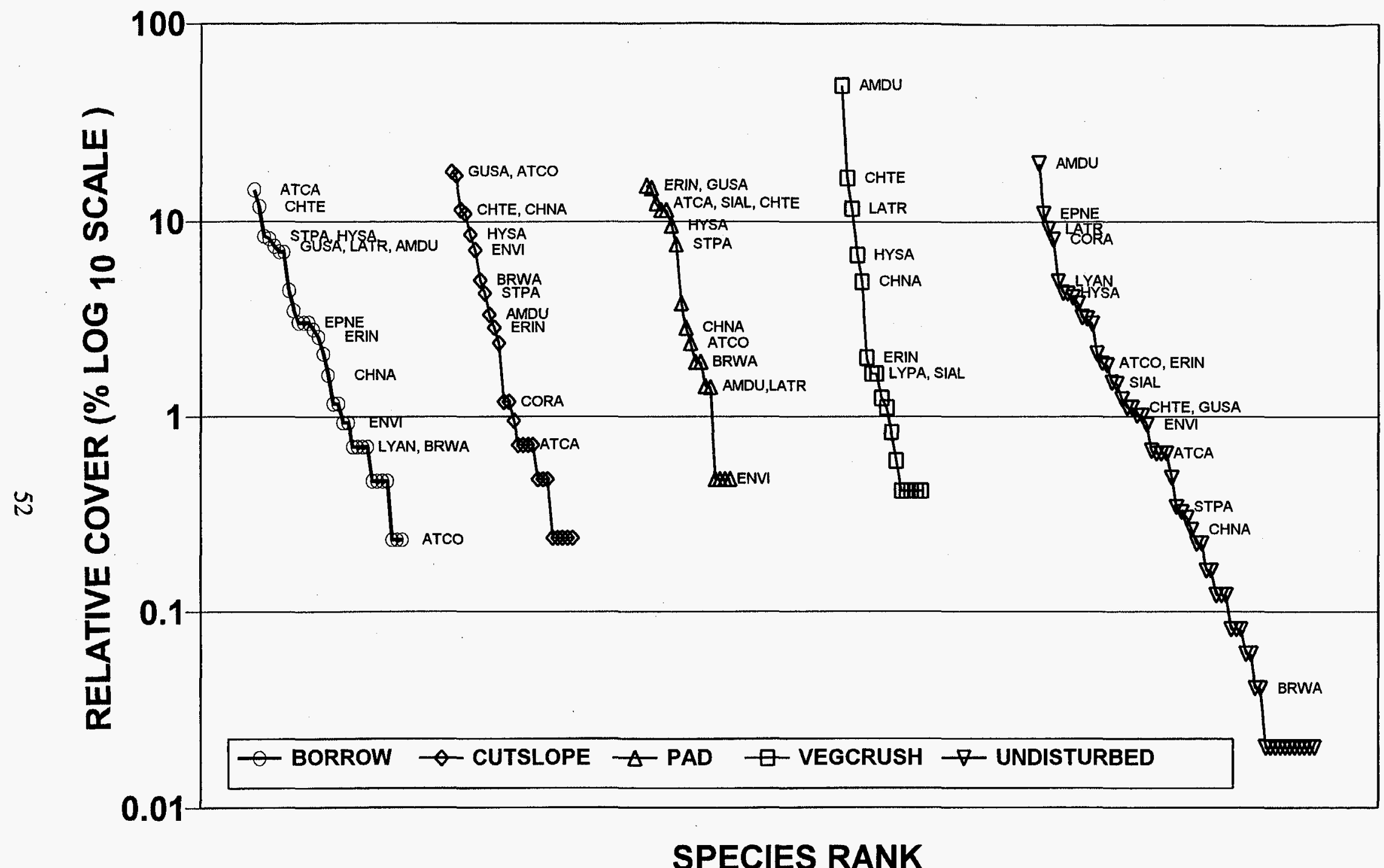

Figure 33. Dominance-diversity curves for relative cover (\%) of perennial plant species for disturbance types and undisturbed areas Yucca Mountain, NV. The disturbance types were as follows: borrow areas (BORROW), cutslopes (CUTSLOPE), drill pads (PAD), and areas with crushed vegetation (VEGCRUSH). Species shown were the top seven dominant species in disturbance types and undisturbed areas. For explanation of species codes, see Appendix Table 1. 


\subsection{DISCUSSION}

\subsection{ENVIRONMENTAL VARIABLES INFLUENCING DISTURBED SITE SUCCESSION}

Disturbed site revegetation at Yucca Mountain was primarily influenced by site location and soil properties. The differences in sites, as displayed by their correlations with the location and soil environmental variables, indicate the site-specific nature of the environmental influences at Yucca Mountain. As seen in the canonical correspondence analysis biplots, individual sites and perennial plant species could be grouped according to their positive and negative correlations with the dominant environmental variables (Figures 12, 13, 17, and 21).

Elevation was the most highly correlated variable in the canonical correspondence analysis across sites. The correlation of elevation with species composition and abundance on disturbances was an indication of the soil and microclimate differences imposed by the change in elevation from the summit of Yucca Mountain down to Forty-Mile wash (Figure 3). Species compositional differences along this gradient were evident in the CCA biplot for perennial species (Figure 13). Species such as $C$. ramosissima, $A$. tridentata, and $H$. jamesii had the greatest cover at high elevations while $A$. shockleyi and $C$. paniculatus had the greatest cover at low elevations, indicating the habitat preferences for these species. When sites were categorized by vegetation associations, elevation continued to play a dominant role in species composition and abundance on the disturbed sites within the Lycium-Grayia and the LarreaLycium-Grayia vegetation associations (Figures 17 and 21).

Across sites, soils factors were the other dominating environmental variables. Degree of soil compaction, percent soil gravel, soil potassium, and percent sand influenced the species composition and abundance on the disturbed sites. As with elevation, certain perennial species were highly correlated with specific soil factors (Figure 13). The high degree of variability in sites was again an indication of the site-specific responses to disturbance.

For the purposes of reclamation planning, it is important to know the factors that will influence the success or failure of reclamation at a site. In this study, the determination of the environmental variables influencing disturbed site succession will aid in deciding how these variables can be used or manipulated to improve the success of reclamation. In the case of elevation, this is location specific, and cannot be manipulated. However, soil factors, in most cases, can be manipulated. Soil compaction could be alleviated by ripping or disking. Low amounts of potassium could be mitigated by adding fertilizer. In the case of the LyciumGrayia vegetation association, the amount of precipitation for the first three years after disturbance was a dominant environmental variable, especially for sites in the low elevational range for this association. This could be mitigated by irrigating a site for the first three years after seeding the site.

The disturbance type also appeared to have an influence on the species composition and abundance on disturbances at Yucca Mountain. The specific environmental factors influencing 
each disturbance type could not be gleaned from the data since they were scattered across the elevational gradient; however, the individual disturbance types did differ in species composition and in relative amounts of forbs, grasses and shrubs (Figures 29 and 31). Some of the effects of disturbance type could be mitigated in reclamation. Borrow areas could have topsoil respread over the sites to improve the growth medium. Cutslopes, if lacking in sufficient soil, could have topsoil imported to them and respread. Drill pads, in many cases, were constructed with imported soil used to level the pad. These soils tended to be very compacted compared to other disturbance types. Compaction could be alleviated by ripping or disking.

Each disturbed site at Yucca Mountain differs by the disturbance type and the environmental variables influencing plant species composition and abundance. Because these influences vary by site, and as with elevation, some cannot be manipulated, reclamation plans should to be prepared on a site-specific basis.

\subsection{DISTURBED SITE PLANT SPECIES}

A. dumosa, $C$. teretifolius, $H$. salsola, $G$. sarothrae, A. confertifolia, A. canescens, and $S$. pauciflora were the most dominant plants across all disturbed sites at Yucca Mountain with subsets of these species being dominants in each of the vegetation associations (Figures 8, 15, $19,23,26)$. These species generally have characteristics of being prolific seed producers and/or have windblown seeds. Rowlands et al. (1980) report that, in the Mojave Desert, the majority of species dominating sites after a disturbance tend to have wind disseminated seed. C. teretifolius, G. sarothrae, and S. pauciflora produce small seeds with tufts of hair that are easily dispersed by wind. $H$. salsola, $A$. confertifolia, A. canescens, and $A$. confertifolia produce winged seeds. A. dumosa is a prolific seeder (Vasek, 1983) that produces bur-type seeds that can be dispersed by wind or in the fur of passing animals.

Topsoil was removed from most of the disturbances inventoried in this study, thus removing most of the native seedbank. Recruitment of new plants into these disturbances appears to have been via windblown seed from the adjacent undisturbed areas. The low abundance or complete absence of species such as $E$. nevadensis, $L$. andersonii, and $M$. spinescens (Figure 7) may partially confirm this. E. nevadensis and $M$. spinescens have heavy seeds (when compared to the windblown seeds) that may depend on rodent caching or overland flow of water for dispersal. Otherwise, these species establish in close proximity to the mother plants. $L$. andersonii has small seed contained in a fleshy fruit. This species' dispersal may depend on rodent caching or by birds eating the fruit and later dispersing the seeds via their feces. The lack of vegetative cover on disturbances may reduce rodent caching because of increased chance of being preyed upon, and the lack of vertical structure provided by larger shrubs may reduce bird use of the sites, thus, reducing fecal deposition of seeds. Therefore, recruitment of $E$. nevadensis, $M$. spinescens, and $L$. andersonii from seed may be limited to the disturbed/undisturbed vegetation edge. 
The species described above that have established readily on disturbed sites may or may not be suitable for use in reclamation at Yucca Mountain. Since many of these species on disturbances were not major components of the undisturbed sites (the exception was $A$. dumosa), they may not be suitable if the long-term objective of reclamation at Yucca Mountain is to return disturbances to a form and productivity similar to that of the undisturbed site (as stated in the Draft Reclamation Plan for Yucca Mountain, DOE, 1989). An understanding of how species dominant in disturbed sites influence the long-term succession of sites is important in determining the suitability of a species for use in reclamation. Connell and Slatyer (1977) outlined three models of succession after disturbance: 1) facilitation, 2) tolerance and 3) inhibition. The facilitation model describes a process where early successional species facilitate the ingress and establishment of later successional species (Pickett et al., 1987). The tolerance model describes a process where species establishment is dependent on whether it can tolerate the initial conditions of the disturbed site (Pickett et al., 1987). The inhibition model describes a process where later successional species cannot establish in the presence of a healthy early successional plant community (Pickett et al., 1987). If species dominating disturbed sites at Yucca Mountain act as facilitators, then their use would be beneficial for reclaiming disturbances. However, if the species that readily establish on disturbed sites inhibit or at least increase the time for establishment of the species that dominated the site prior to disturbance, then they are not suitable for reclamation. Conditions at the disturbed sites could be so harsh that species dominating disturbances are the only species that can tolerate the conditions. Research needs to be conducted at Yucca Mountain to determine whether species dominating disturbances are facilitators, inhibitors, or tolerators. Results from these studies will aid in determining the use of these species for reclamation.

Species could also be selected based on their locations in the canonical correspondence analysis biplot for perennial species (Figure 13, 17, and 21). The cover of $L$. andersonii, $L$.

tridentata, $A$. dumosa, and $G$. spinosa was correlated with the amount of sand in the soil, with greater cover of these species on site with sandy soils. $B$. watsonii cover was correlated with soil gravel amounts. This species may be suitable on sites where the amount of soil gravel cannot be changed via topsoil addition or some other means. A portion of the disturbed sites within the LLG vegetation association were correlated with exchangeable sodium in the soil (Figure 21). A. canescens and $P$. fremontii cover was highly correlated to exchangeable sodium giving an indication that these species may be suitable for use on this type of site.

\subsection{NATURAL REVEGETATION SUCCESS}

For the purposes of this study, the "success" of natural revegetation (secondary succession) will be defined as how similar disturbed plant community attributes (perennial cover, density and species richness) are to those of adjacent undisturbed areas. This is based on the criterion by which the success of revegetation by site reclamation will be measured at Yucca Mountain. The Draft Reclamation Program Plan for Site Characterization (DOE, 1989) states "the objective of the DOE reclamation program at Yucca Mountain is to return land disturbed by site characterization activities to a stable ecological state with a form and productivity similar to the predisturbance state". Using this criterion, plant communities on the disturbed sites at 
Yucca Mountain appear to be quite different from the undisturbed sites in regard to their species richness, total density, and total cover of perennials (Figures 6, 8, 9).

Across all sites, the perennial plant species found on the disturbed sites were also found in the undisturbed sites; however, the dominant species on disturbed sites were generally quite different from the undisturbed areas. Disturbed areas were dominated by species that generally had low cover in the undisturbed areas. This trend has been documented in other studies of Mojave Desert disturbances (Wells, 1961; Webb and Wilshire, 1980; Vasek, 1983; Webb et al., 1983). Apparently, the factors described above regarding seed dissemination and establishment influence this trend.

The low cover values and complete absence of the undisturbed dominant species in the disturbed sites is another indication that natural revegetation has not been successful up to this point. The dominant species on undisturbed sites are a critical component in providing the original form and productivity of a site. Vasek (1983) states that species dominating undisturbed sites are usually long-lived perennials that respond strongly and negatively to disturbance, and require long periods of time to re-establish. However, once these species become established, they can persist for several hundred years. The re-establishment of many of the species dominating undisturbed sites onto disturbed sites at Yucca Mountain may be hampered by seed production and specific germination requirements of these species. For example, $C$. ramosissima, produces seed, on average, every five years, and requires at least a 14 day period of freezing temperatures for the majority of seeds to germinate (Pendelton et al., 1993). Sheps (1973) reported establishment of Larrea tridentata seedlings after a period of high temperatures and high rainfall in Death Valley (a rare combination of events in the Mojave desert); however, only $16 \%$ of the seedlings survived after one year. Barbour (1968) reported that the conditions for optimal germination (in the laboratory) of $L$. tridentata were: darkness, a temperature of $23{ }^{\circ} \mathrm{C}\left(73^{\circ} \mathrm{F}\right)$, leaching mericarps with running water, exposure to cold temperatures prior to sowing, and maintaining the sowing medium at near-zero osmotic pressure and low in salts. The author stated that the combination of these events may be a rare occurrence in the natural environment of deserts. G. spinosa, a dominant in the LyciumGrayia vegetation association, requires a cool, moist, seedbed throughout the late fall and winter months in order to have optimal germination in the spring (Shaw et al., 1994). The specific requirements and the narrow range of tolerance displayed by these species may hinder their establishment in most years.

The lack of natural revegetation "success" on disturbed sites at Yucca Mountain may also be the result of the type and condition of the disturbance. Webb et al. (1983) state that conditions of the disturbed site may be so different from the undisturbed community (e.g. degree of compaction, amount of topsoil, etc) that the resulting plant community may have a species composition and abundance that is strikingly different from the undisturbed site. If these conditions persist, the site may never be similar to the predisturbance plant community. Since the majority of the disturbances at Yucca Mountain have had topsoil removed, bedrock exposed, or are compacted, the conditions may be so harsh that the successional trend may be toward a plant community different from the undisturbed sites. Because this is a point in time 
study and these disturbances are relatively young, future visits to these disturbances will be required to determine a more accurate description of the successional trend.

\subsection{SUCCESSION RATES}

Average perennial density and cover on disturbed sites was 30 to $37 \%$ less than that of undisturbed sites after an average of 10 years. The estimated succession rate, based on the "optimistic" linear extrapolation, indicated that perennial plant cover (without consideration to the species composition and abundance comprising the cover) would reach that of the undisturbed areas after 20 years (Figure 11). The succession rates estimated using the logarithmic extrapolation can be viewed as a more probable rate of recovery because this function more closely represents plant community growth rates. Vasek et al. (1975b) stated that secondary succession in the Mojave desert would be expected to have "slow initial regeneration, rapid intermediate development during an exponential phase, and then slow and very slow development during senescence or during an asymptotic approach to final conditions". Succession rates estimated with the logarithmic extrapolation indicated rapid increases in cover during the first five years with the increase in cover increasing very slowly thereafter. An estimated 845 years would be required for cover on disturbances to reach that of undisturbed areas with this extrapolation.

The above described succession rates for perennial plant cover do not take into consideration the species composition and abundances that comprise the cover. As seen in Figure 7, the species comprising the total plant cover on disturbances were quite different from the undisturbed sites. If disturbed sites are compared to undisturbed sites with regard to the undisturbed site species composition and abundance, individual recovery rates for the ten undisturbed dominant species (based on cover and the linear relationship) ranged from 31 years (A. dumosa) to 1,100 years (G. spinosa) (Table 1$)$. If the end product of secondary succession on these disturbed sites is to have a plant community similar to that of the undisturbed sites, then the time required for this to occur is probably much greater than that estimated above for the "optimistic" linear extrapolation and the "more probable" logarithmic extrapolation.

The succession rates described above for cover are slightly different, but fall within the range of those reported elsewhere in the literature for Mojave Desert disturbances. Webb and Wilshire (1983) reported a rate of approximately 40 years for cover (regardless of species composition and abundance) to be replenished on disturbances at the Wahmonie townsite in Area 25. These authors estimated that total recovery, based on the undisturbed site cover, density, and species richness, would take 200 to 1,000 years. Lathrop (1983) reported rates of 45 to 112 years for cover and 76 to 212 years for density to recover on areas disturbed by military maneuvers. The author attributed the ranges in recovery times to the differences in soil compaction at the sites. Vasek (1983) reported that total recovery of disturbed sites in the Mojave desert would require several centuries to several thousand years depending on the degree of disturbance at the site. 
An understanding of the rate and success of secondary succession at Yucca Mountain is very important for determining the cost/benefit of reclamation. A benefit of using reclamation is that it will speed the successional process with the use of appropriate site preparation techniques and plant materials. Reclamation is a feasible alternative to natural revegetation at Yucca Mountain, not only because it reduces the time required for the disturbed site to return to its original form and productivity, but it is also beneficial for controlling erosion on disturbed sites and reducing the visual impacts caused by the disturbance. Reclamation studies being conducted now and in the future at Yucca Mountain will aid in determining how successful reclamation is compared to the rate and success of natural revegetation. 


\subsection{CONCLUSIONS}

1. Secondary succession on disturbed sites at Yucca Mountain was highly variable with respect to environmental parameters measured. Elevation was the most important variable influencing the composition and abundance of perennial plant species across disturbances. Soil compaction, soil potassium, soil gravel and amount of sand in the soil were other important environmental parameters.

2. A. dumosa, C. teretifolius, $H$. salsola, G. sarothrae, A.confertifolia, A. canescens, and $S$. pauciflora were the most dominant plants across all disturbed sites at Yucca Mountain with subsets of these species being dominants in each of the vegetation associations.

3. With the exception of $A$. dumosa, species that dominated disturbed sites were generally minor components of the undisturbed areas.

4. The form and productivity of disturbed sites is markedly different from that of undisturbed sites. Using the criterion set forth in the Draft Reclamation Program Plan, natural revegetation on disturbances at Yucca Mountain, after an average of 10 years, has not met the reclamation goal.

5. The time required for cover to be similar to that of undisturbed areas was estimated to be 20 years for an optimistic recovery rate and 845 years for the more probable recovery rate. However, the time required for the species composition and abundance in disturbances to approach that of undisturbed areas may require even more time than the above estimates. 


\subsection{RECOMMENDATIONS}

1. Site-specific reclamation plans developed for disturbed sites should include considerations for elevation, vegetation association, species composition and abundances in adjacent undisturbed areas, soil properties, and the type of disturbance. Reclamation trials should be implemented to investigate ways to mitigate, manipulate, or benefit from the site-specific circumstances imposed by disturbed site location, soil properties, and disturbance type.

2. Reclamation studies should be conducted to determine whether the use of pioneer species (i.e. those species dominating disturbed sites) will enhance the successional process and meet the objectives of the reclamation program at Yucca Mountain.

3. Studies should be conducted to assess why dominant species in the undisturbed areas are minor components on disturbed sites, and how to enhance the establishment of these species on disturbed sites. Information from these studies will aid in the development of mitigation procedures for site-specific reclamation.

4. A portion of these disturbed sites should be selected along the elevational gradient and monitored every five years to determine if the successional trend is toward that of the original species composition and abundance, or if these disturbances continue to have a plant community is different from the adjacent undisturbed areas.

5. Results from reclamation studies should be compared to this study and future disturbed site succession studies to verify that the rate and success of reclamation is sufficiently greater than that of natural revegetation of disturbed sites. 


\subsection{LITERATURE CITED}

Barbour, M. G. 1968. Germination requirements of the desert shrub Larrea divaricata. Ecol. 49:915-923.

Beatley, J. C. 1976. Vascular Plants of the Nevada Test Site and Central Southern Nevada: ecologic and geographic distributions. Technical Information Center, Office of Technical Information, Energy Research and Development Administration, Springfield, Virginia. $308 \mathrm{pp}$.

Buckner, D. L. 1985. Point-intercept sampling in revegetation studies; maximizing objectivity and repeatability. Proc. Amer. Soc. Surface Mining and Reclamation Meetings.

Carpenter, D. E., M. G. Barbour, and C.J. Bahre. 1986. Old field succession in Mojave Desert scrub. Madrono 33:111-122.

Connell, J. H. and R. O. Slatyer. 1977. Mechanisms of succession in natural communities and their role in community stability and organization. Amer. Naturalist 11:11191144.

DOE (U. S. Department of Energy). 1989. Draft Reclamation Program Plan for Site Characterization. U.S. Department of Energy, Office of Civilian Radioactive Waste Management, Washington, D.C., Report No. DOE/RW-0244.

DOE (U. S. Department of Energy). 1990. Draft Yucca Mountain Reclamation Feasibility Plan. U.S. Department of Energy, Office of Civilian Radioactive Waste Management, Las Vegas, NV, Report No. DOE/YMP 90-10.

Hickman, J. C. 1993. The Jepson Manual: Higher Plants of California. University of California Press, Berkeley. 1400 pp.

Kent, M. and P. Coker. 1992. Vegetation description and analysis: a practical approach. CRC Press, Boca Raton, FL. 363 pp.

Lathrop E. W. 1983. Recovery of perennial vegetation in military maneuver areas. pages 265-277 In R. H. Webb and H.G. Wilshire (ed.) Environmental effects of off-road vehicles. Springer-Verlag Publishing, New York.

Lathrop E. W., and E. F. Archbold. 1980. Plant response to utility right of way construction in the Mojave Desert. Environ. Manange. 4:215-226. 
Lathrop E. W and P. G. Rowlands. 1983. Plant ecology in deserts. pages 113-152 In R. H. Webb and H.G. Wilshire (ed.) Environmental effects of off-road vehicles. SpringerVerlag Publishing, New York.

Munz, P.A. 1979. A Flora of Southern California. University of California Press, Berkeley. $1086 \mathrm{pp}$.

O'Farrell, T. P., and E. Collins. 1984. 1983 biotic studies of Yucca Mountain, Nevada Test Site, Nye County, NV. EG\&G/EM Santa Barbara Operations, Report No. 102822031.

Pendleton, B. K., S. E. Meyer, R. L. Pendleton. 1993. Blackbrush biology: some insights after three years of long-term study. In: B. A. Roundy, E. D. McArthur, J. S. Haley, and D.K. Mann (comps.) Proceedings: wildland shrub and arid land restoration symposium. 1993 October 19-21, Las Vegas, NV. Gen. Tech. Report INT-GTR-315; Ogden UT: U.S. Dept. of Agriculture, Forest Service, Intermountain Forest and Range Experiment Station.

Pickett, S. T. A., S. L. Collins, and J. J. Armesto. 1987. Models, mechanisms, and pathways of succession. Botanical Rev. 53:335-371.

Romney, E. M., A. Wallace, and R. B. Hunter. 1989. Pulse establishment of woody shrubs on denuded mojave desert land. In: A. Wallace, E. D. McArthur, and M. R. Haferkamp (comps.), Proceedings: symposium on shrub ecophysiology and biotechnology. 1987 June 30-July 2, Logan, UT. Gen. Tech. Report INT-256; Ogden UT: U.S. Dept. of Agriculture, Forest Service, Intermountain Forest and Range Experiment Station. $183 \mathrm{pp}$.

Romney, E. M., A. Wallace, and R. B. Hunter. 1980. The pulse hypothesis in the establishment Artemisia seedlings at Pahute Mesa, Nevada. Great Basin Naturalist Memoirs 4:28-30.

Rowlands, P. G., J. A. Adams, H. B. Johnson, and A. S. Endo. 1980. Experiments on the effects of soil compaction on establishment, cover and pattern of winter annuals in the Mojave Desert. In: P. G. Rowlands (ed.), The Effects of Disturbance on Desert Soils, Vegetation and Community Processes with Emphasis on Off-Road Vehicles. U.S. Dept. of Interior Bureau of Land Management, Desert Plan Staff Special Publication, Riverside, CA. pp. 135-164.

Shaw, N. L., M. R. Haferkamp, and E. G. Hurd. 1994. Germination and seedling establishment of spiny hopsage in response to planting date and seedbed environment. J. Range. Manage. 47:165-174. 
Sheps, L. O. 1973. Survival of Larrea tridentata seedlings in Death Valley National Monument,California. Israel J. Bot. 22:8-17.

Shields, L. M., and P. Wells V. 1962. Effects of nuclear testing on desert vegetation. Science 135:38-40.

Shields, L. M., P. Wells V, and W. H. Rickard. 1963. Vegetational recovery on atomic target areas in Nevada. Ecol. 44:697-705.

ter Braak, C. J. F. 1986. Canonical correspondence analysis: a new eigenvector method for multivariate direct gradient analysis. Ecology. 67:1167-1179.

Vasek, F. C. 1979/80. Early successional stages in Mojave Desert scrub vegetation. Israel J. Bot. 28:133-148.

Vasek, F. C. 1983. Plant succession in the Mojave Desert. Crossosoma 9:1-28.

Vasek, F. C., H. B. Johnson, and G. D. Brum. 1975a. Effects of power transmission lines on vegetation of the Mojave Desert. Madrono 23:114-131.

Vasek, F. C., H. B. Johnson, and D.H. Eslinger. 1975b. Effects of pipeline construction on creosote bush scrub vegetation of the Mojave Desert. Madrono 23:1-13.

Wallace A., E. M. Romney, and R. B. Hunter. 1980. The challenge of a desert: Revegetation of disturbed desert lands. Great Basin Naturalist Memoirs 4:216-225.

Webb, R. H., and H. G. Wilshire. 1980. Recovery of soils and vegetation in a Mojave desert ghost town, Nevada, U.S.A. J. Arid Environ. 3:291-303.

Webb, R. H., J. W. Steiger, and E. B. Newman. 1988. The response of vegetation to disturbance in Death Valley National Monument, California. U.S. Geological Survey Bulletin 1793. U.S Dept. of Interior, Washington, D.C. 103 pp.

Webb, R. H., H. G. Wilshire, and Mary Ann Henry. 1983. Natural recovery of soils and vegetation following human disturbance. pages 279-302 In R. H. Webb and H.G. Wilshire (ed.) Environmental effects of off-road vehicles. Springer-Verlag Publishing, New York.

Wells, P., V. 1961. Succession in desert vegetation on streets of a Nevada ghost town. Science 134:670-671. 
10.0 APPENDIX 
Appendix Table 1. Codes, scientific names, common names, life cycle and growthform of plant species found in undisturbed and disturbed areas at Yucca Mountain, NV. Common names follow those used by Beatley (1976), Munz (1979) and Hickman (1993).

\begin{tabular}{|c|c|c|c|c|}
\hline Code & Scientific Name & Common Name & $\begin{array}{l}\text { Life } \\
\text { Cycle }^{1}\end{array}$ & $\begin{array}{l}\text { Growth } \\
\text { Form }^{2}\end{array}$ \\
\hline $\mathrm{ACSH}$ & Acamptopappus shockleyi & Goldenhead & $\mathbf{P}$ & $S$ \\
\hline AMDU & Ambrosia dumosa & Bursage & $\mathrm{P}$ & $S$ \\
\hline AMTE & Amsinckia tessellata & Bristly fiddleneck & AW & $\mathrm{F}$ \\
\hline ARFE & Aristida fendleriana & & $\mathrm{P}$ & G \\
\hline ARPU & Aristida pupurea & Purple threeawn & $\mathbf{p}$ & $\mathbf{G}$ \\
\hline ARSP & Artemesia spinescens & Budsage & $\mathrm{P}$ & $S$ \\
\hline ARTR & Artemesia tridentata var, tridentata & Big sagebrush & $P$ & $\mathrm{~S}$ \\
\hline ASAC & Astragalus acutirostris & Locoweed & AW & $\mathrm{F}$ \\
\hline ASLA & Astragalus layneae & Layne's locoweed & $P$ & $\mathrm{~F}$ \\
\hline ATCA & Atriplex canescens var. canescens & Fourwing saltbush & $\mathrm{P}$ & $\mathrm{S}$ \\
\hline ATCO & Atriplex confertifolia & Shadscale & $\mathbf{P}$ & $\mathbf{S}$ \\
\hline BRRU & Bromus rubens & Red brome & AW & $\mathrm{F}$ \\
\hline BRTE & Bromus tectorum & Cheat grass & AW & $\mathbf{F}$ \\
\hline BRWA & Brickellia watsonii & Brickellbush & $\mathbf{P}$ & $\mathrm{S}$ \\
\hline $\mathrm{CACH}$ & Castilleja chromosa & Indian paintbrush & $\mathbf{P}$ & $\mathrm{F}$ \\
\hline CAFL & Calochortus flexuosus & Desert lilly & $\mathbf{P}$ & $\mathrm{F}$ \\
\hline CAHE & Camissonia heterochroma & Shockley's evening primrose & A & $\mathrm{F}$ \\
\hline CAMSPP & Camissonia species & & A & $\mathrm{F}$ \\
\hline CELA & Ceratoides lanata & Winterfat & $\mathbf{P}$ & $\mathbf{S}$ \\
\hline CHBR & Chorizanthe brevicornu var. brevicornu & Brittle spineflower & AW & $\mathrm{F}$ \\
\hline CHNA & Chrysothamnus nauseosus ssp. leiospermus & Rubber rabbitbrush & $\mathrm{P}$ & $\mathbf{S}$ \\
\hline CHPA & Chrysothamnus paniculatus & Black-stem rabbitrush & $\mathbf{P}$ & $\mathbf{S}$ \\
\hline CHRI & Chorizanthe rigida & Devil's spiny herb & AW & $\mathrm{F}$ \\
\hline CHSPP & Chaenactis species & & AW & $\mathrm{F}$ \\
\hline CHST & Chaenactis stevioides & Steves duskymaiden & AW & $\mathrm{F}$ \\
\hline CHTE & Chrysothamnus teretifolius & Needle leaf rabbitbrush & $\mathbf{P}$ & $\mathbf{S}$ \\
\hline CHTH & Chorizanthe thurberi & Spineflower & $\mathrm{AW}$ & $\mathrm{F}$ \\
\hline CHVI & Chrysothamnus viscidiflorus ssp. stenophyllus & Yellow rabbitbrush & $\mathbf{P}$ & $\mathbf{S}$ \\
\hline CORA & Coleogyne ramosissima & Blackbrush & $\mathbf{P}$ & $\mathbf{S}$ \\
\hline CRCI & Cryptantha circumscissa & Matted Cryptantha & $\mathrm{AW}$ & $\mathrm{F}$ \\
\hline
\end{tabular}




\begin{tabular}{|c|c|c|c|c|}
\hline Code & Scientific Name & Common Name & $\begin{array}{l}\text { Life } \\
\text { Cycle }^{1}\end{array}$ & $\begin{array}{l}\text { Growth } \\
\text { Form }\end{array}$ \\
\hline CRMI & Cryptantha micrantha & Cryptantha & AW & F \\
\hline CRNE & Cryptantha nevadensis var. nevadensis & Cryptantha & AW & F \\
\hline CRPT & Cryptantha pterocarya & Winged Cryptantha & AW & F \\
\hline CRSPP & Cryptantha species & & AW & $\mathrm{F}$ \\
\hline DEPA & Delphinium parishii var. parishii & Desiert larkspur & $\mathbf{P}$ & $\mathbf{F}$ \\
\hline DEPI & Descurainia pinnata ssp. glabra & Pinnate tansymustard & AW & $\mathrm{F}$ \\
\hline DESO & Descurainia sophia & Tansy-mustard & AW & F \\
\hline DIPU & Dichelostemma pulchellum & Bluedick & $\mathbf{P}$ & F \\
\hline ECEN & Echinocereus engelmanii var. engelmannii & Hedgehog cactus & $\mathbf{P}$ & $\mathrm{C}$ \\
\hline ECPO & Echinocactus polycephalus & Cottontop barrelcactus & $\mathbf{P}$ & $\mathrm{C}$ \\
\hline ENVI & Encelia virginensis ssp. virginensis & Brittlebush & $\mathbf{P}$ & $S$ \\
\hline EPNE & Ephedra nevadensis & Nevada Mormon tea & $P$ & $S$ \\
\hline EPVI & Ephedra viridis & Green Ephedra & $\mathbf{P}$ & $\mathrm{S}$ \\
\hline ERCI & Erodium cicutarium & Storksbill & AW & F \\
\hline ERDE & Eriogonum deflexum var. nevadense & Skeletonweed & AW & $\mathrm{F}$ \\
\hline ERER & Eriastrum eremicum & Eriastrum & AW & $\mathbf{F}$ \\
\hline ERFA & Eriogonum fasciculatum var. polifolium & California buckwheat & $\mathbf{P}$ & $\mathrm{s}$ \\
\hline ERIN & Eriogonum inflatum & Desert trumpet & $\mathbf{P}$ & F \\
\hline ERMA & Eriogonum maculatum & Rose/white & AW & $\mathbf{F}$ \\
\hline ERMI & Eriogonum microthecum var. foliosum & Buckwheat & $\mathrm{P}$ & $\mathrm{s}$ \\
\hline ERNI & Eriogonum nidularium & Buckwheat & AW & $\mathrm{F}$ \\
\hline ERPR & Eriophyllum pringlei & Pringle's wooly leaf & AW & $\mathrm{F}$ \\
\hline ERPU & Erioneuron pulchellum & Fluff grass & $\mathbf{P}$ & G \\
\hline ERSP & Eriastrum sparsiflorum & Eriastrum & A & F \\
\hline ERUM & Eriogonum umbellatum & Sulfur flower & $\mathrm{P}$ & $\mathrm{F}$ \\
\hline ESMI & Eschscholzia minutiflora & Pygmy poppy & AW & $\mathrm{F}$ \\
\hline EUAL & Euphorbia albamarginata & Rattlesnake weed & $\mathbf{P}$ & $\mathrm{F}$ \\
\hline EUMI & Euphorbia micromera & Leafy spurge & AS & $\mathrm{F}$ \\
\hline GIFL & Gilia flavocincta & Gilia & $\mathrm{AW}$ & F \\
\hline GISPP & Gilia species & & AW & F \\
\hline GRSP & Grayia spinosa & Spiny hopsage & $\mathbf{P}$ & $\mathrm{S}$ \\
\hline GUSA & Gutierrezia sarothrae & Matchweed & $P$ & $S$ \\
\hline
\end{tabular}


Appendix Table 1. Continued.

\begin{tabular}{|c|c|c|c|c|}
\hline Code & Scientific Name & Common Name & $\begin{array}{l}\text { Life } \\
\text { Cycle }^{1}\end{array}$ & $\begin{array}{l}\text { Growth } \\
\text { Form }\end{array}$ \\
\hline $\mathrm{HACO}$ & Haplopappus cooperi & Goldenbush & $\mathbf{P}$ & $\mathrm{S}$ \\
\hline HAGL & Halogeton glomeratus & Halogeton & A & $\mathrm{F}$ \\
\hline HALI & Haplopappus linearifolius & Interior goldenbush & $\mathbf{P}$ & $S$ \\
\hline HIJA & Hilaria jamesii & Galleta & $\mathbf{P}$ & G \\
\hline HYSA & Hymenoclea salsola & Burrobrush & $\mathbf{P}$ & $S$ \\
\hline JUOS & Juniperus osteosperma & Dwarf Juniper & $\mathrm{P}$ & $\mathrm{T}$ \\
\hline KRPA & Krameria parvifolia & Ratany & $\mathbf{P}$ & $S$ \\
\hline LASC & Langloisia schottii & Shott's calico & AW & $\mathrm{F}$ \\
\hline LATR & Larrea tridentata & Creosote bush & $\mathrm{P}$ & $\mathbf{S}$ \\
\hline LEDE & Lepidium densiflorum & Prairie pepperweed & $\mathbf{P}$ & $\mathbf{F}$ \\
\hline LEFR & Lepidium fremontii & Desert pepperweed & $\mathbf{P}$ & $\mathrm{F}$ \\
\hline LELA & Lepidium lasiocarpum & & AW & $\mathbf{F}$ \\
\hline LEPU & Leptodactylon pungens ssp. hallii & Prickly gila & $\mathbf{P}$ & $\mathbf{S}$ \\
\hline LOHU & Lotus humistratus & Foothill deervetch & AW & $\mathrm{F}$ \\
\hline LUCO & Lupinus concinnus var. orcuttii & Bajada Lupine & AW & $\mathbf{F}$ \\
\hline LUFL . & Lupinus flavoculatus & Lupine & AW & $\mathrm{F}$ \\
\hline LUPIN & Lupinus species & & A & $\mathrm{F}$ \\
\hline LUSP & Lupinus sparsiflorus & Coulter's Lupine & A & $\mathrm{F}$ \\
\hline LYAN & Lycium andersonii & Box thorn & $\mathbf{P}$ & $\mathbf{S}$ \\
\hline LYPA & Lycium pallidum var. obligospermum & Wolfberry & $\mathbf{P}$ & $\mathbf{S}$ \\
\hline MACA & Machaeranthera canescens var. canescens & & $\mathbf{P}$ & $\mathrm{F}$ \\
\hline MAGL & Malacothrix glabrata & Smooth tooth dandelion & AW & $\mathrm{F}$ \\
\hline MATO & Machaeranthera tortifolia var. tortifolia & Desert-aster & $\mathrm{P}$ & $\mathrm{F}$ \\
\hline MEOB & Mentzelia obscura & Silverstems & AW & $\mathrm{F}$ \\
\hline MESP & Menodora spinescens & Menodora & $\mathrm{P}$ & $\mathbf{S}$ \\
\hline MIBI & Mirabilis bigelovii & Desert wishbone bush & $\mathrm{P}$ & $\mathrm{F}$ \\
\hline MOBE & Monoptilon bellidiforme & Desert star & AW & $\mathrm{F}$ \\
\hline MUPO & Muhlenbergia porteri & Bush muhly & $\mathbf{P}$ & $\mathbf{G}$ \\
\hline NADE & Nama demissum var, demissum & & AW & $\mathrm{F}$ \\
\hline OPBA & Opuntia basilaris var. basilaris & Beavertail pricklypear & $\mathrm{P}$ & $\mathrm{C}$ \\
\hline OPEC & Opuntia echinocarpa var. echinocarpa & Strawtop pricklypear & $\mathrm{P}$ & $\mathrm{C}$ \\
\hline ORHY & Oryzopsis hymenoides & Indian ricegrass & $\mathrm{P}$ & $\mathrm{G}$ \\
\hline
\end{tabular}


Appendix Table 1. Continued.

\begin{tabular}{|c|c|c|c|c|}
\hline Code & Scientific Name & Common Name & $\begin{array}{l}\text { Life } \\
\text { Cycle }^{1}\end{array}$ & $\begin{array}{l}\text { Growth } \\
\text { Form }^{2}\end{array}$ \\
\hline OXPE & Oxytheca perfoliata & Roundleaf spineflower & AW & $\mathrm{F}$ \\
\hline PEPL & Pectocarya platycarpa & Pectocarya & AW & $\mathrm{F}$ \\
\hline PESE & Pectocarya setosa & & AW & $\mathrm{F}$ \\
\hline PHFR & Phacelia fremontii & Freemont's Pacelia & AW & $\mathrm{F}$ \\
\hline PHRO & Phacelia rotundifolia & & A & $\mathrm{F}$ \\
\hline PHSPP & Phacelia species & & AW & $\mathrm{F}$ \\
\hline PSAN & Psathyrotes annua & Turtleback & A & $\mathrm{F}$ \\
\hline PSFR & Psorothamnus fremontii var. fremontii & Indigo bush & $\mathbf{P}$ & $\mathbf{S}$ \\
\hline RANE & Rafinesquia neomexicana & New Mexico plumseed & AW & $\mathrm{F}$ \\
\hline SAIB & Salsola iberica & Russian thistle & A & $\mathrm{F}$ \\
\hline SAME & Salazaria mexicana & Bladdersage & $\mathbf{P}$ & $\mathrm{S}$ \\
\hline SCAR & Schismus arabicus & Arabian Scismus & AW & G \\
\hline SCPO & Sclerocactus polyancistrus & & $\mathbf{P}$ & $\mathrm{C}$ \\
\hline SIAL & Sisymbrium altissimum & Tumblemustard & PB & $\mathrm{F}$ \\
\hline SIHY & Sitanion hystrix & Squirreltail & $\mathbf{P}$ & G \\
\hline SIJU & Sitanion jubatum & & $\mathbf{P}$ & G \\
\hline SPAM & Sphaeralcea ambigua ssp. ambigua & Globemallow & $\mathbf{P}$ & $\mathrm{F}$ \\
\hline SPCR & Sporobolus cryptandrus & Sand dropseed & $\mathbf{P}$ & G \\
\hline STEX & Stephanomeria exigua ssp. exigua & Small wirelettuce & AW & $\mathrm{F}$ \\
\hline STPA & Stephanomeria pauciflora & Wire-lettuce & $\mathbf{P}$ & $\mathrm{F}$ \\
\hline STSP & Stipa speciosa & Desert needlegrass & $P$ & G \\
\hline SYFR & Syntrichopappus fremontii & Syntrichopappus & AW & $\mathrm{F}$ \\
\hline TEAX & Tetradymia axillaris var. axillaris & Longspine horsebush & $\mathbf{P}$ & $\mathbf{S}$ \\
\hline TEGL & Tetradymia glabrata & Littleleaf horsebush & $\mathrm{P}$ & $\mathrm{S}$ \\
\hline VUOC & Vulpia octoflora & Sixweeks fescue & AW & G \\
\hline YUBR & Yucca brevifolia & Joshua tree & $\mathrm{P}$ & $\mathrm{T}$ \\
\hline
\end{tabular}

\footnotetext{
${ }^{1} \mathrm{~A}=$ Annual, $\mathrm{AW}=$ Annual, Winter growing season, $\mathrm{B}=$ Biennial, $\mathrm{P}=$ Perennial

${ }^{2} \mathrm{C}=$ Cactus, $\mathrm{F}=$ Forb, $\mathrm{G}=$ Grass, $\mathrm{S}=$ Shrub, $\mathrm{T}=$ Tree
} 
Appendix Table 2. Pearson's correlation coefficients (r) for environmental variables used to test for their influence on species composition and abundance in disturbance areas. For long name of the environmental variable, see Appendix Table 3.

\begin{tabular}{|c|c|c|c|c|c|c|c|c|c|c|c|}
\hline $\begin{array}{l}\text { Environmental } \\
\text { Variable }\end{array}$ & Age & Slope & $\begin{array}{l}\text { Elev- } \\
\text { ation }\end{array}$ & Aspect & $\begin{array}{l}\text { Dist. } \\
\text { Area }\end{array}$ & $\begin{array}{r}\text { Grow- } \\
\text { ppt }\end{array}$ & $\begin{array}{r}\text { Gppt- } \\
\text { sum }\end{array}$ & $\begin{array}{r}\text { Gppt- } \\
3 y r \\
\end{array}$ & $\begin{array}{r}\text { Gppt- } \\
5 y r \\
\end{array}$ & Depth & $\begin{array}{r}\text { Cone- } \\
\text { pen }\end{array}$ \\
\hline Age & 1.00 & -0.19 & 0.08 & -0.10 & -0.11 & 0.24 & 0.99 & 0.90 & 0.64 & -0.12 & -0.03 \\
\hline Slope & -0.19 & 1.00 & 0.24 & 0.23 & 0.03 & -0.22 & -0.22 & -0.16 & -0.27 & 0.32 & 0.27 \\
\hline Elevation & 0.08 & 0.24 & 1.00 & -0.09 & -0.08 & -0.47 & 0.02 & 0.17 & -0.26 & -0.03 & 0.35 \\
\hline Aspect & -0.10 & 0.23 & -0.09 & 1.00 & -0.12 & 0.11 & -0.11 & -0.22 & 0.01 & 0.29 & -0.09 \\
\hline Dist. Area & -0.11 & 0.03 & -0.08 & -0.12 & 1.00 & -0.20 & -0.10 & 0.01 & -0.08 & -0.14 & 0.06 \\
\hline Growppt & 0.24 & -0.22 & -0.47 & 0.11 & -0.20 & 1.00 & 0.32 & 0.14 & 0.45 & -0.24 & -0.08 \\
\hline Gpptsum & 0.99 & -0.22 & 0.02 & -0.11 & -0.10 & 0.32 & 1.00 & 0.90 & 0.70 & -0.16 & -0.04 \\
\hline Gppt3yr & 0.90 & -0.16 & 0.17 & -0.22 & 0.01 & 0.14 & 0.90 & 1.00 & 0.38 & -0.20 & -0.01 \\
\hline Gppt5yr & 0.64 & -0.27 & -0.26 & 0.01 & -0.08 & 0.45 & 0.70 & 0.38 & 1.00 & -0.11 & -0.07 \\
\hline Depth & -0.12 & 0.32 & -0.03 & 0.29 & -0.14 & -0.24 & -0.16 & -0.20 & -0.11 & 1.00 & -0.38 \\
\hline Conepen & -0.03 & 0.27 & 0.35 & -0.09 & 0.06 & -0.08 & -0.04 & -0.01 & -0.07 & -0.38 & 1.00 \\
\hline PerGrav & 0.17 & -0.08 & 0.17 & -0.13 & -0.02 & 0.13 & 0.21 & 0.29 & 0.13 & -0.37 & 0.13 \\
\hline Satpercent & 0.14 & 0.32 & 0.64 & -0.02 & 0.03 & -0.26 & 0.11 & 0.22 & -0.10 & 0.13 & 0.23 \\
\hline $\mathrm{pH}$ & -0.10 & -0.15 & -0.22 & -0.01 & 0.07 & -0.04 & -0.13 & -0.07 & -0.30 & -0.04 & -0.12 \\
\hline $\mathrm{EC}$ & -0.20 & 0.06 & 0.20 & -0.22 & 0.21 & -0.23 & -0.19 & -0.11 & -0.13 & -0.08 & -0.08 \\
\hline $\mathrm{CaH} 2 \mathrm{O}$ & -0.13 & 0.02 & 0.19 & -0.24 & 0.10 & -0.19 & -0.12 & -0.05 & -0.09 & -0.12 & -0.09 \\
\hline $\mathrm{MgH} 2 \mathrm{O}$ & -0.07 & -0.05 & 0.18 & -0.26 & 0.04 & -0.15 & -0.06 & -0.00 & -0.05 & -0.14 & -0.10 \\
\hline NAH2O & -0.24 & 0.09 & 0.20 & -0.19 & 0.25 & -0.24 & -0.23 & -0.15 & -0.17 & -0.04 & -0.07 \\
\hline SAR & -0.22 & 0.01 & 0.25 & -0.21 & 0.29 & -0.28 & -0.23 & -0.12 & -0.24 & -0.10 & -0.08 \\
\hline CaNH4 & -0.03 & -0.14 & -0.06 & -0.18 & -0.07 & 0.10 & -0.02 & -0.00 & -0.05 & -0.12 & 0.33 \\
\hline $\mathrm{MgNH} 4$ & -0.01 & -0.16 & -0.09 & -0.17 & -0.08 & 0.12 & 0.00 & 0.01 & -0.02 & 0.18 & 0.23 \\
\hline NaNH4 & -0.03 & -0.16 & -0.10 & -0.17 & -0.08 & 0.16 & -0.02 & -0.02 & -0.01 & -0.06 & -0.09 \\
\hline $\mathbf{P}$ & 0.29 & -0.02 & 0.16 & -0.08 & -0.13 & 0.12 & 0.31 & 0.24 & 0.36 & -0.16 & 0.09 \\
\hline K & 0.27 & -0.49 & -0.35 & -0.11 & -0.08 & 0.32 & 0.30 & 0.16 & 0.37 & -0.15 & -0.21 \\
\hline NO3_N & 0.03 & -0.02 & 0.33 & -0.26 & 0.03 & -0.24 & 0.02 & 0.08 & 0.01 & -0.31 & 0.20 \\
\hline $\mathrm{OM}$ & 0.17 & 0.17 & 0.32 & 0.05 & -0.06 & -0.09 & 0.16 & 0.15 & 0.14 & -0.19 & 0.44 \\
\hline CEC & 0.02 & 0.38 & 0.69 & -0.05 & 0.03 & -0.33 & -0.04 & 0.11 & -0.33 & 0.14 & 0.29 \\
\hline Sand & -0.14 & -0.32 & -0.63 & 0.03 & -0.06 & 0.22 & -0.11 & -0.24 & 0.14 & 0.19 & -0.36 \\
\hline Silt & 0.19 & 0.14 & 0.37 & -0.01 & 0.09 & -0.06 & 0.19 & 0.23 & 0.08 & -0.35 & 0.25 \\
\hline Clay & 0.03 & 0.38 & 0.67 & -0.04 & 0.01 & -0.29 & -0.01 & 0.16 & -0.31 & 0.05 & 0.34 \\
\hline Exch. Ca & -0.11 & -0.08 & -0.05 & -0.19 & -0.05 & 0.03 & -0.11 & -0.06 & -0.15 & -0.34 & 0.17 \\
\hline Exch. Mg & -0.01 & -0.17 & -0.11 & -0.17 & -0.08 & 0.13 & 0.00 & 0.00 & -0.01 & 0.06 & -0.13 \\
\hline Exch. Na & -0.02 & -0.17 & -0.10 & -0.17 & -0.08 & 0.12 & -0.00 & 0.00 & -0.02 & -0.16 & -0.14 \\
\hline
\end{tabular}


Appendix Table 2 continued.

\begin{tabular}{|c|c|c|c|c|c|c|c|c|c|c|c|}
\hline $\begin{array}{l}\text { Environmental } \\
\text { Variable } \\
\end{array}$ & $\begin{array}{l}\text { Per- } \\
\text { Grav }\end{array}$ & $\begin{array}{r}\text { Sat- } \\
\text { percent }\end{array}$ & $\mathrm{pH}$ & $\mathrm{EC}$ & $\mathrm{CaH} 2 \mathrm{O}$ & $\mathrm{MgH} 2 \mathrm{O}$ & $\mathrm{NAH} 2 \mathrm{O}$ & SAR & $\mathrm{CaNH} 4$ & MgNH4 & NaNH4 \\
\hline Age & 0.17 & 0.14 & -0.10 & -0.20 & -0.13 & -0.07 & -0.24 & -0.22 & -0.03 & -0.01 & -0.03 \\
\hline Slope & -0.08 & 0.32 & -0.15 & 0.06 & 0.02 & -0.05 & 0.09 & 0.01 & -0.14 & -0.16 & -0.16 \\
\hline Elevation & 0.17 & 0.64 & -0.22 & 0.20 & 0.19 & 0.18 & 0.20 & 0.25 & -0.06 & -0.09 & -0.10 \\
\hline Aspect & -0.13 & -0.02 & -0.01 & -0.22 & -0.24 & -0.26 & -0.19 & -0.21 & -0.18 & -0.17 & -0.17 \\
\hline Dist. Area & -0.02 & 0.03 & 0.07 & 0.21 & 0.10 & 0.04 & 0.25 & 0.29 & -0.07 & -0.08 & -0.08 \\
\hline Growppt & 0.13 & -0.26 & -0.04 & -0.23 & -0.19 & -0.15 & -0.24 & -0.28 & 0.10 & 0.12 & 0.16 \\
\hline Gpptsum & 0.21 & 0.11 & -0.13 & -0.19 & -0.12 & -0.06 & -0.23 & -0.23 & -0.02 & 0.00 & -0.02 \\
\hline Gppt3yr & 0.29 & 0.22 & -0.07 & -0.11 & -0.05 & -0.00 & -0.15 & -0.12 & -0.00 & 0.01 & -0.02 \\
\hline Gppt5yr & 0.13 & -0.10 & -0.30 & -0.13 & -0.09 & -0.05 & -0.17 & -0.24 & -0.05 & -0.02 & -0.01 \\
\hline Depth & -0.37 & 0.13 & -0.04 & -0.08 & -0.12 & -0.14 & -0.04 & -0.10 & -0.12 & 0.18 & -0.06 \\
\hline Conepen & 0.13 & 0.23 & -0.12 & -0.08 & -0.09 & -0.10 & -0.07 & -0.08 & 0.33 & 0.23 & -0.09 \\
\hline PerGrav & 1.00 & 0.07 & -0.03 & -0.08 & -0.07 & -0.06 & -0.08 & -0.01 & -0.01 & -0.01 & -0.01 \\
\hline Satpercent & 0.07 & 1.00 & -0.39 & 0.16 & 0.14 & 0.10 & 0.16 & 0.16 & -0.13 & -0.15 & -0.16 \\
\hline $\mathrm{pH}$ & -0.03 & -0.39 & 1.00 & -0.15 & -0.29 & -0.31 & -0.06 & 0.20 & 0.38 & 0.37 & 0.35 \\
\hline EC & -0.08 & 0.16 & -0.15 & 1.00 & 0.91 & 0.84 & 0.98 & 0.82 & -0.00 & -0.02 & -0.00 \\
\hline $\mathrm{CaH} 2 \mathrm{O}$ & -0.07 & 0.14 & -0.29 & 0.91 & 1.00 & 0.98 & 0.80 & 0.59 & -0.03 & -0.04 & -0.03 \\
\hline $\mathrm{MgH} 2 \mathrm{O}$ & -0.06 & 0.10 & -0.31 & 0.84 & 0.98 & 1.00 & 0.70 & 0.51 & -0.01 & -0.02 & -0.01 \\
\hline NAH2O & -0.08 & 0.16 & -0.06 & 0.98 & 0.80 & 0.70 & 1.00 & 0.89 & 0.01 & -0.00 & 0.01 \\
\hline SAR & -0.01 & 0.16 & 0.20 & 0.82 & 0.59 & 0.51 & 0.89 & 1.00 & 0.08 & 0.06 & 0.07 \\
\hline CaNH4 & -0.01 & -0.13 & 0.38 & -0.00 & -0.03 & -0.01 & 0.01 & 0.08 & 1.00 & 1.00 & 0.97 \\
\hline MgNH4 & -0.01 & -0.15 & 0.37 & -0.02 & -0.04 & -0.02 & -0.00 & 0.06 & 1.00 & 1.00 & 0.97 \\
\hline NaNH4 & -0.01 & -0.16 & 0.35 & -0.00 & -0.03 & -0.01 & 0.01 & 0.07 & 0.97 & 0.97 & 1.00 \\
\hline $\mathbf{P}$ & 0.16 & 0.17 & -0.58 & -0.13 & -0.02 & 0.03 & -0.20 & -0.33 & -0.21 & -0.20 & -0.21 \\
\hline $\mathbf{K}$ & -0.20 & -0.32 & 0.16 & -0.10 & 0.00 & 0.08 & -0.15 & -0.14 & 0.52 & 0.54 & 0.56 \\
\hline NO3_N & 0.05 & 0.23 & -0.06 & 0.62 & 0.57 & 0.56 & 0.59 & 0.61 & 0.27 & 0.25 & 0.17 \\
\hline $\mathrm{OM}$ & -0.07 & 0.30 & -0.36 & 0.06 & 0.12 & 0.13 & 0.02 & -0.08 & -0.22 & -0.24 & -0.24 \\
\hline CEC & -0.06 & 0.78 & -0.13 & 0.21 & 0.14 & 0.10 & 0.25 & 0.30 & 0.07 & 0.04 & 0.04 \\
\hline Sand & -0.10 & -0.63 & 0.34 & -0.15 & -0.19 & -0.21 & -0.12 & -0.15 & 0.15 & 0.17 & 0.20 \\
\hline Silt & 0.20 & 0.24 & -0.26 & 0.11 & 0.18 & 0.24 & 0.06 & 0.10 & -0.02 & -0.03 & -0.07 \\
\hline Clay & -0.05 & 0.79 & -0.30 & 0.13 & 0.13 & 0.11 & 0.14 & 0.15 & -0.22 & -0.24 & -0.26 \\
\hline Exch. $\mathrm{Ca}$ & 0.04 & -0.15 & 0.46 & 0.00 & -0.00 & 0.01 & 0.01 & 0.12 & 0.95 & 0.94 & 0.91 \\
\hline Exch. Mg & -0.01 & -0.18 & 0.38 & -0.02 & -0.04 & -0.02 & -0.01 & 0.05 & 1.00 & 1.00 & 0.97 \\
\hline Exch. $\mathrm{Na}$ & -0.01 & -0.17 & 0.38 & -0.01 & -0.03 & -0.01 & 0.01 & 0.07 & 1.00 & 1.00 & 0.97 \\
\hline
\end{tabular}


Appendix Table 2 continued.

\begin{tabular}{|c|c|c|c|c|c|c|c|c|c|c|c|}
\hline $\begin{array}{l}\text { Environmental } \\
\text { Variable }\end{array}$ & $\mathrm{P}$ & $\mathbf{K}$ & $\mathrm{NO} 3 \mathrm{~N}$ & $\mathrm{OM}$ & CEC & Sand & Silt & Clay & $\begin{array}{r}\text { Exch. } \\
\mathrm{Ca} \\
\end{array}$ & $\begin{array}{r}\text { Exch. } \\
\mathrm{Mg}\end{array}$ & $\begin{array}{r}\text { Exch. } \\
\mathrm{Na}\end{array}$ \\
\hline Age & 0.29 & 0.27 & 0.03 & 0.17 & 0.02 & -0.14 & 0.19 & 0.03 & -0.11 & -0.01 & -0.02 \\
\hline Slope & -0.02 & -0.49 & -0.02 & 0.17 & 0.38 & -0.32 & 0.14 & 0.38 & -0.08 & -0.17 & -0.17 \\
\hline Elevation & 0.16 & -0.35 & 0.33 & 0.32 & 0.69 & -0.63 & 0.37 & 0.67 & -0.05 & -0.11 & -0.10 \\
\hline Aspect & -0.08 & -0.11 & -0.26 & 0.05 & -0.05 & 0.03 & -0.01 & -0.04 & -0.19 & -0.17 & -0.17 \\
\hline Dist. Area & -0.13 & -0.08 & 0.03 & -0.06 & 0.03 & -0.06 & 0.09 & 0.01 & -0.05 & -0.08 & -0.08 \\
\hline Growppt & 0.12 & 0.32 & -0.24 & -0.09 & -0.33 & 0.22 & -0.06 & -0.29 & 0.03 & 0.13 & 0.12 \\
\hline Gpptsum & 0.31 & 0.30 & 0.02 & 0.16 & -0.04 & -0.11 & 0.19 & -0.01 & -0.11 & 0.00 & -0.00 \\
\hline Gppt3yr & 0.24 & 0.16 & 0.08 & 0.15 & 0.11 & -0.24 & 0.23 & 0.16 & -0.06 & 0.00 & 0.00 \\
\hline Gppt5yr & 0.36 & 0.37 & 0.01 & 0.14 & -0.33 & 0.14 & 0.08 & -0.31 & -0.15 & -0.01 & -0.02 \\
\hline Depth & -0.16 & -0.15 & -0.31 & -0.19 & 0.14 & 0.19 & -0.35 & 0.05 & -0.34 & 0.06 & -0.16 \\
\hline Conepen & 0.09 & -0.21 & 0.20 & 0.44 & 0.29 & -0.36 & 0.25 & 0.34 & 0.17 & -0.13 & -0.14 \\
\hline PerGrav & 0.16 & -0.20 & 0.05 & -0.07 & -0.06 & -0.10 & 0.20 & -0.05 & 0.04 & -0.01 & -0.01 \\
\hline Satpercent & 0.17 & -0.32 & 0.23 & 0.30 & 0.78 & -0.63 & 0.24 & 0.79 & -0.15 & -0.18 & -0.17 \\
\hline $\mathrm{pH}$ & -0.58 & 0.16 & -0.06 & -0.36 & -0.13 & 0.34 & -0.26 & -0.30 & 0.46 & 0.38 & 0.38 \\
\hline $\mathrm{EC}$ & -0.13 & -0.10 & 0.62 & 0.06 & 0.21 & -0.15 & 0.11 & 0.13 & 0.00 & -0.02 & -0.01 \\
\hline $\mathrm{CaH} 2 \mathrm{O}$ & -0.02 & 0.00 & 0.57 & 0.12 & 0.14 & -0.19 & 0.18 & 0.13 & -0.00 & -0.04 & -0.03 \\
\hline $\mathrm{MgH} 2 \mathrm{O}$ & 0.03 & 0.08 & 0.56 & 0.13 & 0.10 & -0.21 & 0.24 & 0.11 & 0.01 & -0.02 & -0.01 \\
\hline $\mathrm{NAH} 2 \mathrm{O}$ & -0.20 & -0.15 & 0.59 & 0.02 & 0.25 & -0.12 & 0.06 & 0.14 & 0.01 & -0.01 & 0.01 \\
\hline SAR & -0.33 & -0.14 & 0.61 & -0.08 & 0.30 & -0.15 & 0.10 & 0.15 & 0.12 & 0.05 & 0.07 \\
\hline CaNH4 & -0.21 & 0.52 & 0.27 & -0.22 & 0.07 & 0.15 & -0.02 & -0.22 & 0.95 & 1.00 & 1.00 \\
\hline MgNH4 & -0.20 & 0.54 & 0.25 & -0.24 & 0.04 & 0.17 & $-0: 03$ & -0.24 & 0.94 & 1.00 & 1.00 \\
\hline NaNH4 & -0.21 & 0.56 & 0.17 & -0.24 & 0.04 & 0.20 & -0.07 & -0.26 & 0.91 & 0.97 & 0.97 \\
\hline $\mathrm{P}$ & 1.00 & 0.18 & 0.19 & 0.62 & -0.01 & -0.33 & 0.40 & 0.14 & -0.28 & -0.21 & -0.21 \\
\hline $\mathrm{K}$ & 0.18 & 1.00 & 0.13 & 0.11 & -0.27 & 0.15 & 0.11 & -0.36 & 0.43 & 0.54 & 0.54 \\
\hline NO3_N & 0.19 & 0.13 & 1.00 & 0.32 & 0.26 & -0.32 & 0.34 & 0.18 & 0.27 & 0.24 & 0.25 \\
\hline OM & 0.62 & 0.11 & 0.32 & 1.00 & 0.22 & -0.47 & 0.45 & 0.32 & -0.22 & -0.24 & -0.24 \\
\hline CEC & -0.01 & -0.27 & 0.26 & 0.22 & 1.00 & -0.73 & 0.31 & 0.87 & 0.01 & 0.02 & 0.02 \\
\hline Sảnd & -0.33 & 0.15 & -0.32 & -0.47 & -0.73 & 1.00 & -0.82 & -0.82 & 0.17 & 0.19 & 0.19 \\
\hline Silt & 0.40 & 0.11 & 0.34 & 0.45 & 0.31 & -0.82 & 1.00 & 0.34 & -0.03 & -0.04 & -0.04 \\
\hline Clay & 0.14 & -0.36 & 0.18 & 0.32 & 0.87 & -0.82 & 0.34 & 1.00 & -0.25 & -0.26 & -0.26 \\
\hline Exch. Ca & -0.28 & 0.43 & 0.27 & -0.22 & 0.01 & 0.17 & -0.03 & -0.25 & 1.00 & 0.94 & 0.94 \\
\hline Exch. Mg & -0.21 & 0.54 & 0.24 & -0.24 & 0.02 & 0.19 & -0.04 & -0.26 & 0.94 & 1.00 & 1.00 \\
\hline Exch. Na & -0.21 & 0.54 & 0.25 & -0.24 & 0.02 & 0.19 & -0.04 & -0.26 & 0.94 & 1.00 & 1.00 \\
\hline
\end{tabular}


Appendix Table 3. Code names and explanations for environmental variables used to determine their influence on species composition and abundance of plants on disturbed areas at Yucca Mountain, NV.

Environmental

Variable

Code

Environmental Variable and Units

Age

Slope

Elevation

Aspect

Dist. Area

Growppt

Gpptsum

N Gppt3yr

Gppt5yr

Depth

Conepen

PerGrav

Satpercent

$\mathrm{pH}$

EC

$\mathrm{CaH} 2 \mathrm{O}$

$\mathrm{MgH} 2 \mathrm{O}$

NAH2O

SAR

$\mathrm{CaNH} 4$

$\mathrm{MgNH} 4$

$\mathrm{NaNH} 4$

$\mathrm{P}$

$\mathrm{K}$
Years since initial disturbance

Slope (\%)

Elevation (ft)

Aspect (degrees)

Disturbance Area (ha)

Growing Season Precipitation (mm) - First year after initial disturbance

Growing Season Precipitation (mm) - Sum of all years after initial disturbance

Growing Season Precipitation (mm) - Sum of first 3 years after initial disturbance

Growing Season Precipitation (mm) - Sum of first 5 years after initial disturbance

Depth Penetrometer reading $(\mathrm{cm})$

Cone Penetrometer reading $(\mathrm{kg} / \mathrm{cm} 2)$

Percent Gravel $>2 \mathrm{~mm}$ in the soil

Soil Saturation Percentage

Soil pH

Soil Electrical Conductivity

Water soluable Calcium (meq/L of soil solution)

Water soluable Magnesium (meq/L of soil solution)

Water soluable Sodium (meq/L soil solution)

Sodium Absorption Ratio

NH4 Extractable Calcium (meq/100 g of soil)

NH4 Extractable Magnesium (meq/100 g soil)

NH4 Extractable Sodium (meq/100 g soil)

Phosphorus ( $\mathrm{mg} / \mathrm{kg}$ of soil)

Potassium (mg/kg of soil) 
Appendix Table 3. continued

Environmental

Variable

Code

Environmental Variable and Units

$\begin{array}{ll}\text { NO3_N } & \text { Nitrate Nitrogen }(\mathrm{mg} / \mathrm{kg} \text { of soil) } \\ \text { OM } & \text { Soil Organic Matter (percent) } \\ \text { CEC } & \text { Cation Exchange Capacity (meq/100 g of soil } \\ \text { SAND } & \text { Sand (\% by hydrometer) } \\ \text { SILT } & \text { Silt (\% by hydrometer) } \\ \text { CLAY } & \text { Clay (\% by hydrometer) } \\ \text { Exch. } \mathrm{Ca} & \text { Exchangeable Calcium }(\%) \\ \text { Exch. } \mathrm{Mg} & \text { Exchangeable Magnesium }(\%) \\ \text { Exch. } \mathrm{Na} & \text { Exchangeable Sodium }(\%)\end{array}$


DOE/HQ

OSTI (2)

DOE/NV

Technical Information Officer

DOE/YMP

W. R. Dixon

R. M. Nelson, Jr.

M. E. Ryder

DRI Reno

B. W. Schultz

EG\&G/EM YMP/RSL

C. E. Ezra

SAIC

M.W. Harris

T. N. Pysto

EG\&G/EM

P. H. Zavattaro

Technical Information Center

EG\&G/EM NV Program

J. A Michael

T.O. Edwards

\section{EG\&G/EM ESD}

D. C. Anderson

J. P. Angerer

K. W. Blomquist

S. R. Blomquist

G. A. Brown

B. L. Cypher

S. A. Flick

W. D. Gabbert

R. G. Goodwin

R. A. Green

P. D. Greger

D. B. Hall

M. B. Hessing

E. A. Holt

A. L. Hughes

R. B. Hunter

T. T. Kato

V. R. Kelly

T. A. Lindemann

G. E. Lyon

J. M. Mueller

T. P. O'Farrell

W. K. Ostler

D. L. Rakestraw

K. R. Rautenstrauch

M.B. Saethre

G. T. Sharp

K. R. Sharp

C. L. Sowell

D.C. Steen

T. E. Walrath

C. A. Wills

V. K. Winkel

B. D. Woodard

K. K. Zander 